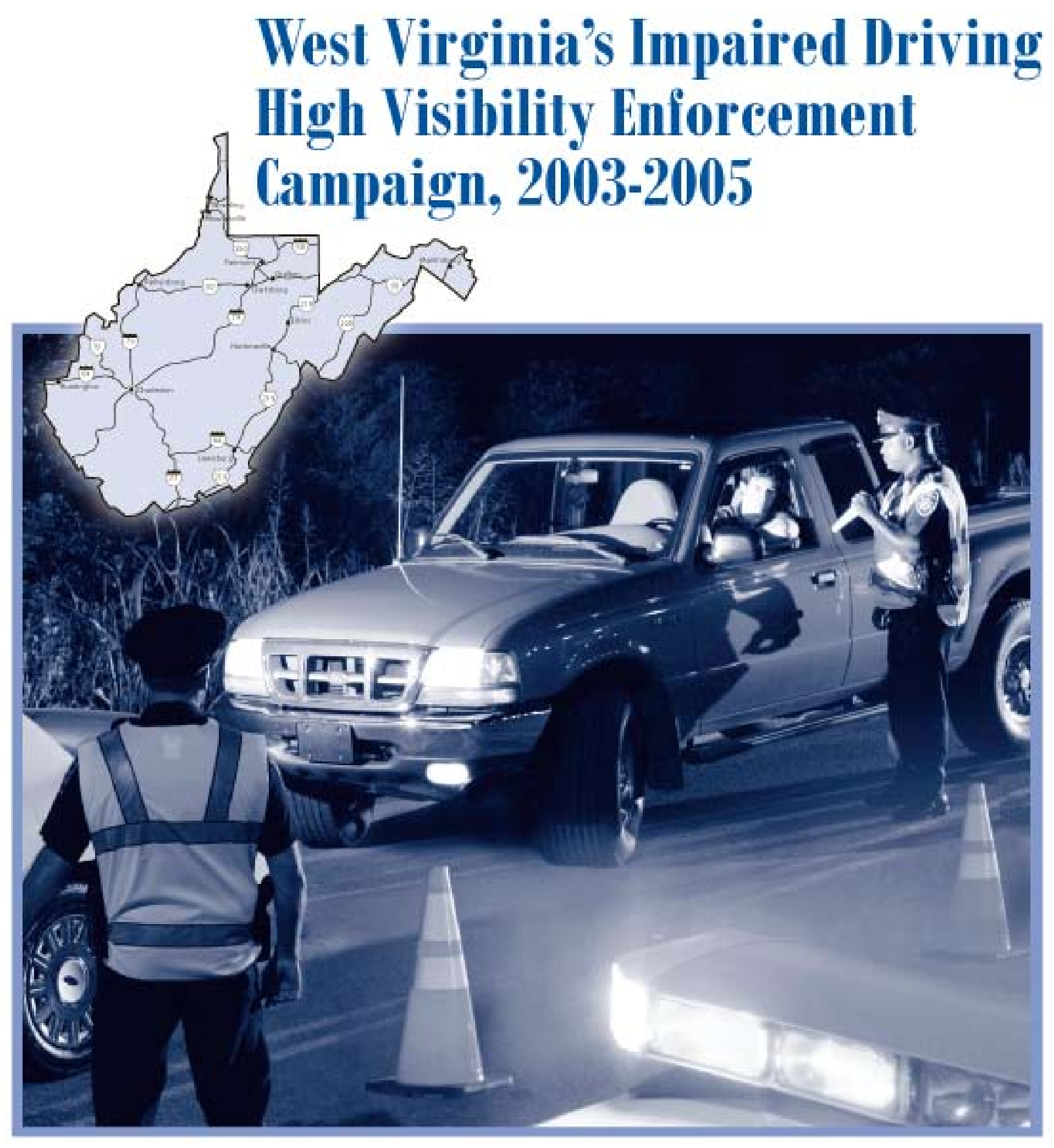

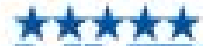

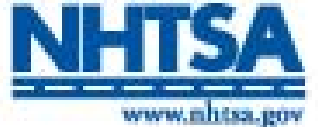


This publication is distributed by the U.S. Department of Transportation, National Highway Traffic Safety Administration, in the interest of information exchange. The opinions, findings, and conclusions expressed in this publication are those of the authors and not necessarily those of the Department of Transportation or the National Highway Traffic Safety Administration. The United States Government assumes no liability for its contents or use thereof. If trade or manufacturers' names or products are mentioned, it is because they are considered essential to the object of the publication and should not be construed as an endorsement. The United States Government does not endorse products or manufacturers. 


\begin{tabular}{|c|c|c|c|c|c|}
\hline \multicolumn{2}{|l|}{$\begin{array}{l}\text { 1. Report No. } \\
\text { DOT HS } 810792\end{array}$} & \multicolumn{2}{|l|}{ 2. Government Accession No. } & \multicolumn{2}{|c|}{ 3. Recipient's Catalog No. } \\
\hline \multicolumn{4}{|l|}{ 4. Title and Subtitle } & \multicolumn{2}{|l|}{ 5. Report Date } \\
\hline \multirow{2}{*}{\multicolumn{4}{|c|}{$\begin{array}{l}\text { West Virgin } \\
\text { Campaign, } 2\end{array}$}} & \multicolumn{2}{|c|}{ August 2007} \\
\hline & & & & \multicolumn{2}{|c|}{ 6. Performing Organization Code } \\
\hline \multicolumn{4}{|l|}{ 7. Author(s) } & \multicolumn{2}{|c|}{ 8. Performing Organization Report No. } \\
\hline \multicolumn{4}{|c|}{ T.J. Zwicker, N. K. Chaudhary, M. G. Solomon, J.N Siegler, and J.D. Meadows } & & \\
\hline \multicolumn{4}{|c|}{ 9. Performing Organization Name and Address } & \multicolumn{2}{|c|}{ 10. Work Unit No. (TRAIS) } \\
\hline \multicolumn{4}{|c|}{$\begin{array}{l}\text { Preusser Research Group, Inc., and the } \\
\text { WV Governor's Highway Safety Office }\end{array}$} & \\
\hline \multicolumn{4}{|c|}{$\begin{array}{l}7100 \text { Main Street } \\
\text { Trumbull, CT } 06611\end{array}$} & \multicolumn{2}{|c|}{$\begin{array}{l}\text { 11. Contract or Grant No. } \\
\text { NHTSA Contract } \\
\text { DTNH22-98-D-45079 }\end{array}$} \\
\hline \multicolumn{4}{|c|}{$\begin{array}{l}\text { 12. Sponsoring Agency Name and Address } \\
\text { U.S. Department of Transportation } \\
\text { National Highway Traffic Safety Administration }\end{array}$} & \multicolumn{2}{|c|}{$\begin{array}{l}\text { Final Report } \\
\text { January } 2003 \text { - December } 2004\end{array}$} \\
\hline \multicolumn{3}{|c|}{$\begin{array}{l}1200 \text { New Jersey Avenue SE. } \\
\text { Washington, DC } 20590\end{array}$} & & \multicolumn{2}{|c|}{ 14. Sponsoring Agency Code } \\
\hline \multicolumn{6}{|l|}{$\begin{array}{l}\text { 15. Supplementary Notes } \\
\text { The Contracting }\end{array}$} \\
\hline \multicolumn{6}{|c|}{$\begin{array}{l}\text { 16. Abstract } \\
\text { In } 2002 \text {, West Virginia became a Strategic Evaluation State for the National Highway Traffic Safety } \\
\text { Administration's Impaired Driving High-Visibility Enforcement campaign. The State implemented NHTSA's } \\
\text { model publicity and enforcement program in targeted counties to reduce impaired driving and alcohol-related } \\
\text { fatalities. The State spent nearly } \$ 3.4 \text { million on the campaign from } 2003 \text { through } 2005 \text {, or an average of about } \\
62 \text { cents per resident each year. The campaign began during the July } 4 \text { th holiday period in } 2003 \text { and was } \\
\text { sustained for the next } 27 \text { months, running through September } 2005 \text {. Statewide DMV surveys in targeted } \\
\text { counties indicated that drivers reported significantly more often after the campaign that they had heard about } \\
\text { impaired driving in West Virginia and had been through a sobriety checkpoint. Roadside surveys of driver } \\
\text { blood alcohol concentrations (BAC) indicated a significant decrease in the proportion of drivers with a positive } \\
\text { BAC at the end of the campaign compared to the same period the previous year. In addition, autoregressive } \\
\text { integrated moving average analysis performed on the alcohol-related fatality trend for the targeted counties } \\
\text { indicated a significant decrease by an estimated } 1 \text { fewer fatality each month. The total fatalities saved in the } \\
\text { targeted counties totaled about } 18 \text { in the year and a half of data available following the July } 2003 \text { start of the } \\
\text { campaign. }\end{array}$} \\
\hline \multicolumn{3}{|l|}{ 17. Key Words } & \multicolumn{3}{|c|}{ 18. Distribution Statement } \\
\hline $\begin{array}{l}\text { Alcohol } \\
\text { Publicity } \\
\text { DWI } \\
\text { DWI Enforcement }\end{array}$ & \multicolumn{2}{|c|}{$\begin{array}{l}\text { Impaired Driving Countermeasures } \\
\text { Sobriety Checkpoints } \\
\text { BAC testing } \\
\text { Alcohol-Related Fatalities }\end{array}$} & \multicolumn{3}{|c|}{$\begin{array}{l}\text { Document is available through the } \\
\text { National Technical Information Service } \\
\text { Springfield, VA } 22161 \\
\text { www.nhtsa.dot.gov }\end{array}$} \\
\hline \multicolumn{2}{|c|}{ 19. Security Classif.(of this report) } & \multicolumn{2}{|c|}{$\begin{array}{r}\text { 20. Security Classif.(of this page) } \\
\text { Unclassified }\end{array}$} & 21. No. of Pages & 22. Price \\
\hline
\end{tabular}


DEPARTMENT OF TRANSPORTATION

NATIONAL HIGHWAY TRAFFIC SAFETY ADMINISTRATION

TECHNICAL SUMMARY

\begin{tabular}{l|l}
\hline \hline CONTRACTOR & CONTRACT NUMBER \\
Preusser Research Group, Inc. & NHTSA Contract \\
& DTNH22-98-D-45079 \\
\hline REPORT TITLE & REPORT DATE \\
$\begin{array}{l}\text { West Virginia's Impaired Driving High-Visibility Enforcement Campaign, } \\
\text { A003-2005 }\end{array}$ & August 2007 \\
\hline REPORT AUTHOR(S) \\
\begin{tabular}{l} 
T. J. Zwicker, N. K. Chaudhary, M. G. Solomon, J. N. Siegler, and J. D. Meadows \\
\hline
\end{tabular}
\end{tabular}

West Virginia became one of 13 Strategic Evaluation States (SES) in 2002 and committed to follow the National Highway Traffic Safety Administration impaired driving highvisibility enforcement model and conduct high-visibility enforcement during key holiday crackdowns and sustained enforcement between holidays. NHTSA provided paid media to increase awareness of the enforcement during each crackdown.

The campaign consisted of three components: (1) media with an enforcement message, (2) enhanced periods of enforcement surrounding summer and winter holidays focusing on the use of checkpoints, and (3) sustained enforcement between holidays. Labor Day weekend crackdowns replaced July $4^{\text {th }}$ for 2004 and 2005. The model focuses on crackdowns that cover 85 percent of the States' populations and involve high-visibility DWI checkpoints and/or saturation patrols during three weekends (17 days) of these holiday periods. West Virginia selected the following 6 targeted counties for implementation of the model: Berkeley (Martinsburg), Ohio (Wheeling), Kanawha (Charleston), Marion (Fairmont), Raleigh (Beckley), and Wood (Parkersburg).

\section{Paid Media}

Congress appropriated $\$ 11$ million for paid media to support the national impaired driving campaign. Of the total, $\$ 5.5$ million was spent to purchase air time on national TV and the remainder was used to develop the national ad and to purchase media in the 13 Strategic Evaluation States. The 13 States were chosen because of their high alcohol-related fatality trend or high number of alcohol-related fatalities. The TV ad was targeted and placed on TV programs often viewed by young men 21 to 34 because this group is over-represented in alcohol-related 
crashes. On behalf of West Virginia, NHTSA spent $\$ 101,244$ for 576 media spots that ran during the June 20 - July 13, 2003, period (Levy et al., 2004). Later, in December 2003, West Virginia spent $\$ 48,000$ on paid media during the holiday crackdown. In 2004, West Virginia spent $\$ 165,594$ on paid media and, in 2005 ; the State spent $\$ 150,316$ on paid media. In total from 2003 through 2005, West Virginia purchased \$363,910 of paid media to support the highvisibility impaired driving crackdowns. From 2003 through 2005, \$416,838 was spent on media to support high-visibility impaired driving crackdowns.

\section{Enforcement}

The enforcement funds spent by the State totaled $\$ 870,316$ for $2003, \$ 1,021,421$ for 2004 , and $\$ 1,051,864$ for 2005 . About half of the enforcement funds each year came from the West Virginia Commission on Drunk Driving Prevention. West Virginia spent \$3,360,439 from 2003 through 2005, or about 62 cents per resident on average each year on its publicity and enforcement campaign to combat drinking and driving.

Sobriety checkpoints constituted a large part of the enforcement effort, but saturation patrols were the most frequent enforcement method. West Virginia held a total of 810 sobriety checkpoints, saturation patrols, and other enforcement activities in the 6 targeted counties from 2003 through 2005 . The total enforcement averaged 101.67 activities for each targeted county across the three-year period reported here. The total enforcement for non-targeted counties averaged 64.12 activities per county during the same two-and-a-half-year period. The State held an increasing number of sobriety checkpoints and saturation patrols from 2003 through September 2005, particularly in targeted counties.

\section{Program Evaluation}

The evaluation included: Department of Motor Vehicle surveys in 4 of the 6 targeted and 7 of the 49 non-targeted counties, direct observations of drinking and driving at sobriety checkpoints before and after each holiday crackdown, alcohol-related fatality data, and statewide telephone surveys before and after each holiday crackdown. The State conducted DMV surveys conducted before and after each holiday crackdown (for a total of 10 administrations) and roadside surveys in targeted counties occurred monthly from April 2004 through November 2004 and during April, May, and June 2005 (for a total of 11 months). 


\section{Direct Observations of Driver BACs}

Driver blood alcohol concentrations (BACs) were collected at sobriety checkpoints in each targeted county as a direct measure of the effect of enforcement and publicity on drinking and driving. Roadside surveys were conducted in each of the six targeted counties, focusing on the largest towns in each of the counties. The research team obtained voluntary, "blind," anonymous BACs from randomly selected drivers on handheld breath-testing devices. Generally, about 96 percent or more drivers agreed to the BAC test. The team collected 3,202 BAC samples from drivers during 2004 and 993 BAC samples from drivers during April, May, and June 2005.

\section{Alcohol-Related Fatalities}

Alcohol-related fatality data were taken from NHTSA's Fatality Analysis Reporting System (FARS) for 2000 through the preliminary 2004 data. The alcohol-related fatality trend for the targeted counties and the State were analyzed using the autoregressive integrated moving average (ARIMA) technique.

\section{Results and Discussion}

\section{Exposure to Enforcement}

There was a statistically significant 29.7-percentage-point increase from the first 2003 pre-July $4^{\text {th }}$ survey to the post-Labor Day 2005 survey in the number of respondents from targeted counties who reported seeing or hearing something about alcohol-impaired driving in West

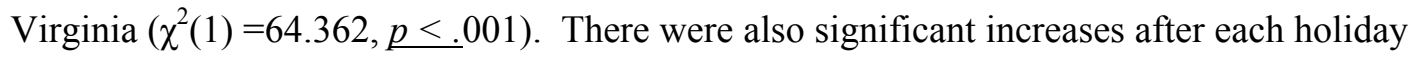
crackdown in targeted counties. There was no overall significant change in non-targeted counties. The proportion of DMV office survey respondents in targeted counties that recognized the "You Drink \& Drive. You Lose" slogan increased by 41 percentage points over the course of the campaign $\left(\left(\chi^{2}(1)=92.789, p<.001\right)\right.$. There was a smaller but significant increase of 21 percentage points for non-targeted counties $\left(\chi^{2}(1)=50.061, \underline{p<.001)}\right.$

The proportion of DMV office survey respondents in the target counties indicating that police "very strictly" enforce the drinking and driving laws increased significantly from the first to the last survey $\left(\chi^{2}(1)=4.731, \underline{p}=.03\right)$. There was no corresponding increase in non-targeted counties. 
There was a significant 12-percentage-point increase in the proportion of drivers reporting that they had been through a sobriety checkpoint in targeted counties from the first to the last DMV office survey $\left(\left(\chi^{2}(1)=16.180, \underline{p<.001)}\right.\right.$. There was no similar increase for nontargeted counties.

\section{Roadside Survey Driver BACs}

There was an overall 2.8-percentage-point, statistically significant decrease in the proportion of drivers with positive BACs when comparing April, May, and June data from 2004 versus $2005\left(\chi^{2}(1)=5.706, p=.017\right)$. The breath test refusal rates for both periods were low. The proportion of male drivers with positive BACs at checkpoints decreased significantly by 3.2

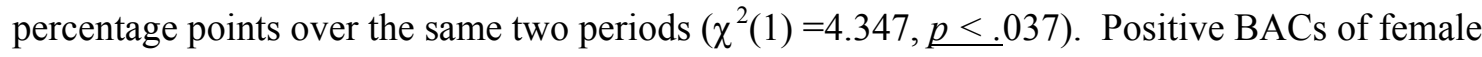
drivers decreased 2.4 percentage points, but the decrease was not significant.

\section{Alcohol-Related Fatalities}

ARIMA model results indicated that there was a significant "sudden and sustained" decrease in the alcohol-related fatality trend for targeted counties in the 18-month period from July 2003 through December 2004 compared to the trend from January 2000 through June 2003 $(\mathrm{p}=.012)$. The estimated reduction in the number of alcohol-related fatalities determined by the ARIMA analysis was .99 lives each month for the 18 months following the beginning of the campaign for a total estimate of about 18 lives saved in the targeted counties (a 24\% reduction). Analyses of the alcohol-related fatalities for men 21 to 34 years old in the targeted counties yielded a predicted reduction of .09 lives per month, but the reduction did not approach statistical significance $(\mathrm{p}=.787)$. The statewide alcohol-related fatality trend also decreased, but not significantly $(\mathrm{p}=.198)$. Figure 2 shows graphically the predicted reduction in alcohol-related fatalities in targeted counties as a result of the campaign. 
West Virginia Alcohol-Related Fatalities for Targeted Counties 2000-2004

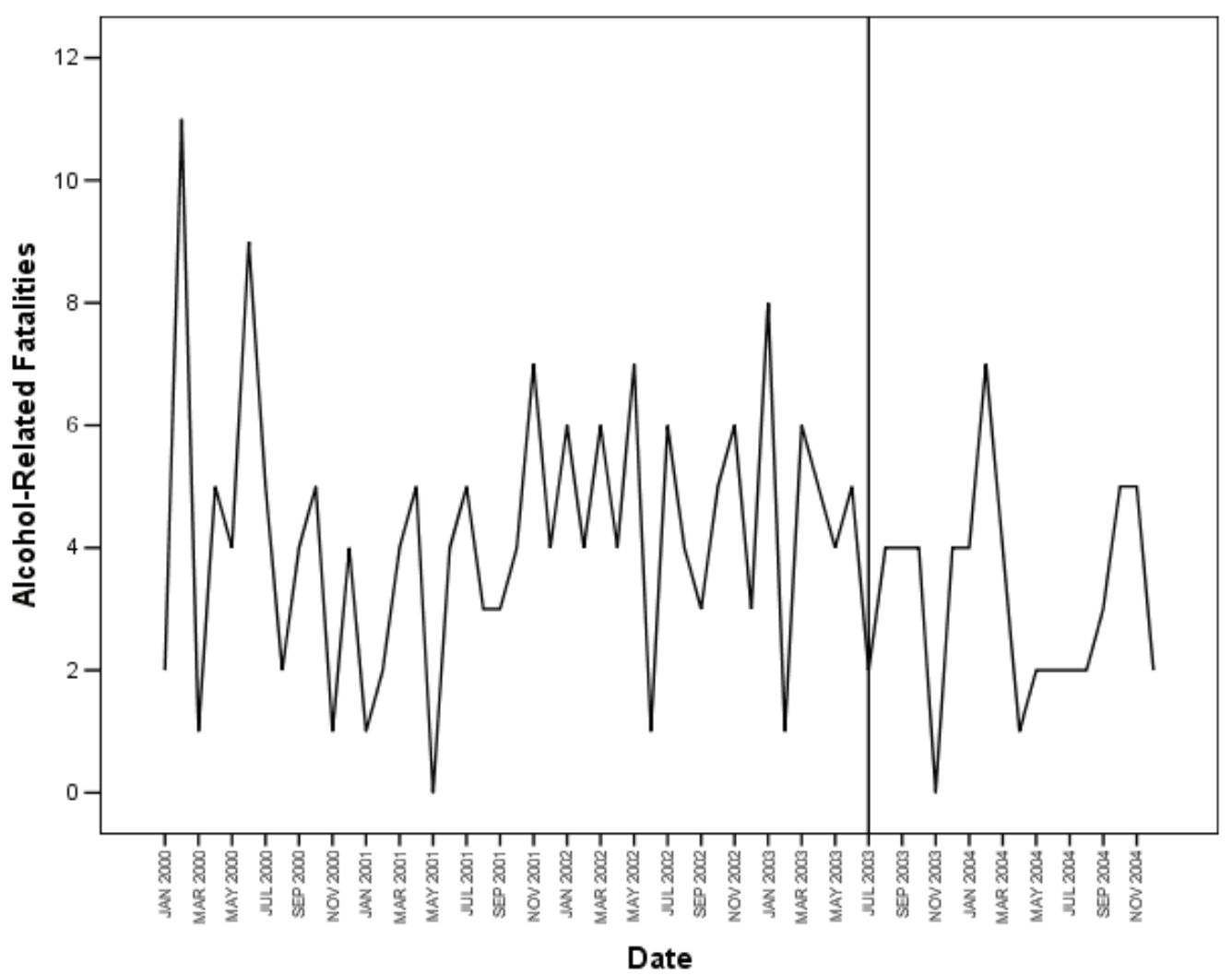

\section{Summary and Conclusions}

West Virginia's impaired driving high-visibility enforcement campaign for targeted counties was designed to reduce impaired driving and ultimately, alcohol-related crash fatalities. The campaign focused on increasing enforcement during holiday periods and on a sustained basis between holiday crackdowns and on increasing awareness of the enforcement using paid media. DMV office surveys for targeted counties indicated that drivers heard the enforcement-based media messages and went through sobriety checkpoints more often.

The campaign also achieved its ultimate goal: significantly reducing the alcohol-related fatality trend in the targeted counties resulting in an estimated 18 lives saved over an 18-month period. 


\section{TABLE OF CONTENTS}

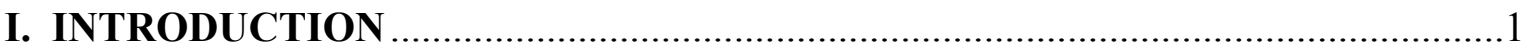

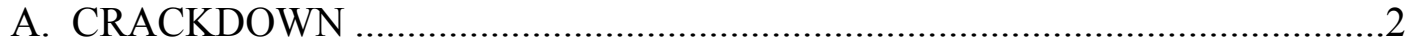

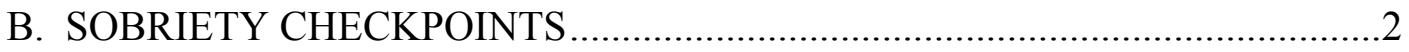

II. STRATEGIC EVALUATION STATE PROGRAM DESCRIPTION ......................3

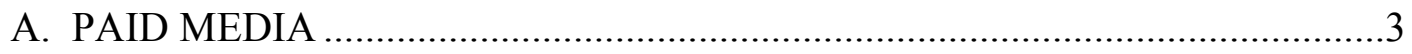

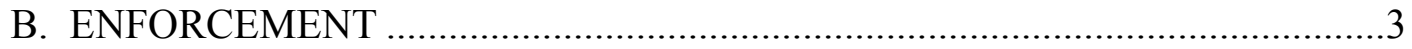

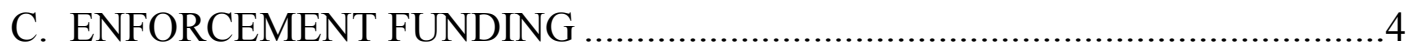

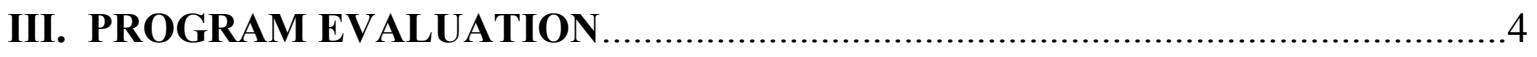

A. WEST VIRGINIA DEPARTMNENT OF MOTOR VEHICLE OFFICE

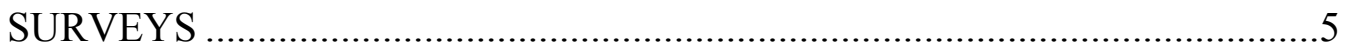

B. WEST VIRGINIA ROADSIDE SURVEY DIRECT MEASURES OF

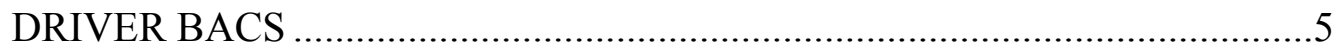

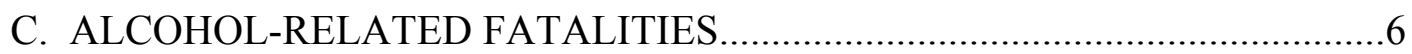

D. WEST VIRGINIA TELEPHONE SURVEYS ………....................................

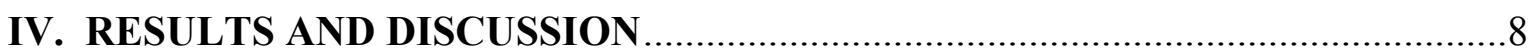

WEST VIRGINIA DEPARTMENT OF MOTOR VEHICLE OFFICE SURVEYS

A. CHARACTERISTICS OF DMV SURVEY RESPONDENTS............................

B. EXPOSURE TO ENFORCEMENT MESSAGE..............................................

C. PERCEPTIONS OF ENFORCEMENT …………….............................................12

D. SELF-REPORTED CHANGES IN DRINKING AND DRIVING ......................14

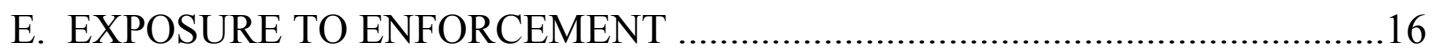

WEST VIRGINIA ROADSIDE SURVEY

F. DIRECT OBSERVATIONS OF DRIVER BACS ……....................................16

G. DRIVER BACS BY TIME OF NIGHT, AGE, AND GENDER ……................18

WEST VIRGINIA ALCOHOL-RELATED FATALITY ANALYSIS USING

FARS 2000-2004

H. ARIMA ANALYSES OF WEST VIRGINIA ALCOHOL-RELATED

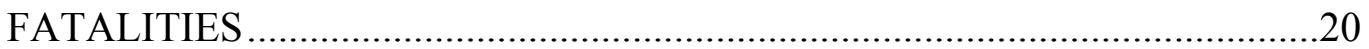

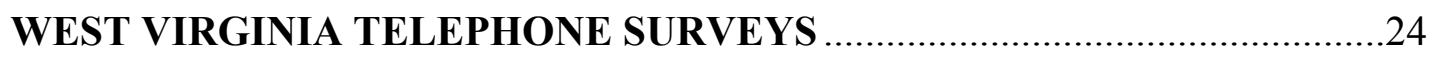

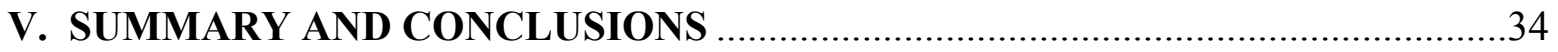

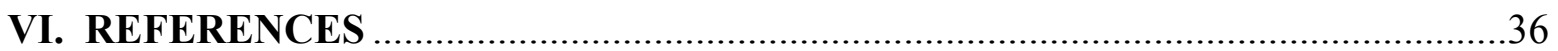

APPENDIX A: WEST VIRGINIA DMV OFFICE SURVEY .......................................

APPENDIX B: WEST VIRGINIA ROADSIDE SURVEY DATA COLLECTION

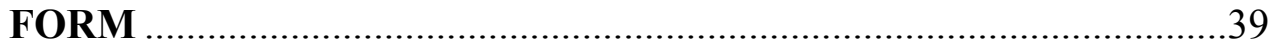

APPENDIX C: WEST VIRGINIA TELEPHONE SURVEY .41 


\section{TABLES AND FIGURES}

Figure 1. West Virginia Number of Alcohol-Related Fatalities From 1992-2002 .........................1

Table 1. Average Number of DWI Enforcement Activities Held in Each Targeted and NonTargeted County by Year

Table 2. West Virginia DMV Survey Q1: Self-Reported Gender by Survey Administration .......9

Table 3. West Virginia DMV Survey Q2: Self-Reported Age Group by Survey Administration.9

Table 4. West Virginia DMV Survey Q3: Self-Reported Race by Survey Administration .9

Table 5. West Virginia DMV Survey Q13: Had Recently Seen or Heard Something About Alcohol Impaired Driving (or Drunk Driving) for Targeted and Non-Targeted Counties..... 10

Table 6. West Virginia DMV Survey Q13: Source if Yes to Recent Seen or Heard Something About Alcohol Impaired Driving (or Drunk Driving) for Targeted and Non-Targeted Counties..11

Table 7. West Virginia DMV Survey Q14: Named One or More Alcohol Impaired Driving Slogans for Targeted and Non-Targeted Counties

Table 8. West Virginia DMV Survey Q10: Public Perception of the Strictness of Police Enforcement of Drinking and Driving Laws for Targeted and Non-Targeted Counties.....

Table 9. West Virginia DMV Survey Q8: Perceived Likelihood of Getting Arrested if You Drive After Drinking for Targeted and Non-Targeted Counties

Table 10. West Virginia DMV Survey Q9: Self-Reported Drinking and Driving Compared to Three Months Ago for Targeted and Non-Targeted Counties

Table 11. West Virginia DMV Survey Q7: Reported Having Driven One or More Times in the Past 30 Days Within Two Hours of Drinking an Alcoholic Beverage for Targeted and Non-

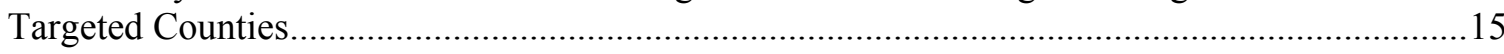

Table 12. West Virginia DMV Survey Q12: Reported Having Gone Through a Sobriety Checkpoint in Past 30 Days for Targeted and Non-Targeted Counties.

Figure 2. West Virginia Roadside Survey: Driver BACs and Refusals (2004 Versus 2005)........17

Table 13. West Virginia Roadside Survey: Driver BACs and Refusals ...................................17

Table 14. West Virginia Roadside Survey: Breath Test Refusal Rates .....................................18

Table 15. West Virginia Roadside Survey: Distribution of Roadside BACs by Category and Hour of Night

Table 16. West Virginia Roadside Survey: Distribution of BACs by Age Group 
Table 17. West Virginia Roadside Survey: Proportion of Drivers at Checkpoints by Age Group and Hour of Night.

Table 18. West Virginia Roadside Survey: Distribution of BACs by Gender

Table 19. West Virginia Targeted County Alcohol-Related Fatality Trend ARIMA Results:

Parameter Estimates for Alcohol-Related Fatalities.

Figure 3. West Virginia Predicted Alcohol-Related Fatalities for Targeted Counties 2000-2004

Table 20. West Virginia Alcohol-Related Fatality Trend Statewide Results Including a Covariate: Parameter Estimates for Alcohol-Related Fatalities Using Alcohol-Related Fatalities From Contiguous Counties as a Covariate

Figure 4. Visibility of Police on Roads: All Respondents and Respondents 18 to 34 Years Old

Figure 5. Seen or Heard Messages Encouraging People Not to Drink: All Respondents and Respondents 18 to 34 Years Old.

Figure 6. Increased Number of Messages Seen or Heard in Past 30 Days: All Respondents and Respondents 18 to 34 Years Old

Figure 7. Seen or Heard Special Efforts by Police to Reduce Drunk Driving: All Respondents and Respondents 18 to 34 Years Old

Figure 8. Awareness of Police Checkpoints: All Respondents and Respondents 18 to 34 Years Old

Figure 9. Unaided Awareness of the "You Drink \& Drive, You Lose" Slogan: All Respondents and Respondents 18 to 34 Years Old

Figure 10. Recall of The "Checkpoint Strikeforce" Slogan: All Respondents and Respondents 18 to 34 Years Old.

Figure 11. Recognition of "You Drink \& Drive, You Lose" Slogan: All Respondents and Respondents 18 to 34 Years Old

Figure 12. Recognition of the State's "Checkpoint Strikeforce" Slogan: All Respondents and Respondents 18 to 34 Years Old.

Figure 13. Recall Seeing a Certain Ad: All Respondents and Respondents 18 to 34 Years Old .30

Figure 14. Drove Within Two Hours of Drinking: All Respondents and Respondents 18 to 34 Years Old.

Figure 15. Mean Number of Days People Drove Within 2 Hours After Drinking and Driving During the Past 30 Days: All Respondents and Respondents 18 to 34 Years Old. 
Figure 16. Admitted to Driving After Drinking Too Much: All Respondents and Respondents 18 to 34 Years Old.

Figure 17. Overall Liklihood of Being Stopped by Police: All Respondents and Respondents 18 to 34 Years Old.

Figure 18. Increased Liklihood of Being Stopped by Police Now: All Respondents and Respondents 18 to 34 Years Old....

Figure 19. Enforcement of Drinking and Driving Laws: All Respondents and Respondents 18 to 34 Years Old. 34 



\section{INTRODUCTION}

West Virginia's alcohol-related fatality trend has remained stable since 1995. Before that, West Virginia experienced consistent decreases over 13 years in the number of alcohol-related fatalities, from a high of 253 in 1983 to a low of 162 in 1994. Figure 1 illustrates the lack of change in the alcohol-related fatality trend from 1996 through 2002.

\section{Figure 1. West Virginia Number of Alcohol-Related Fatalities From 1982-2004}

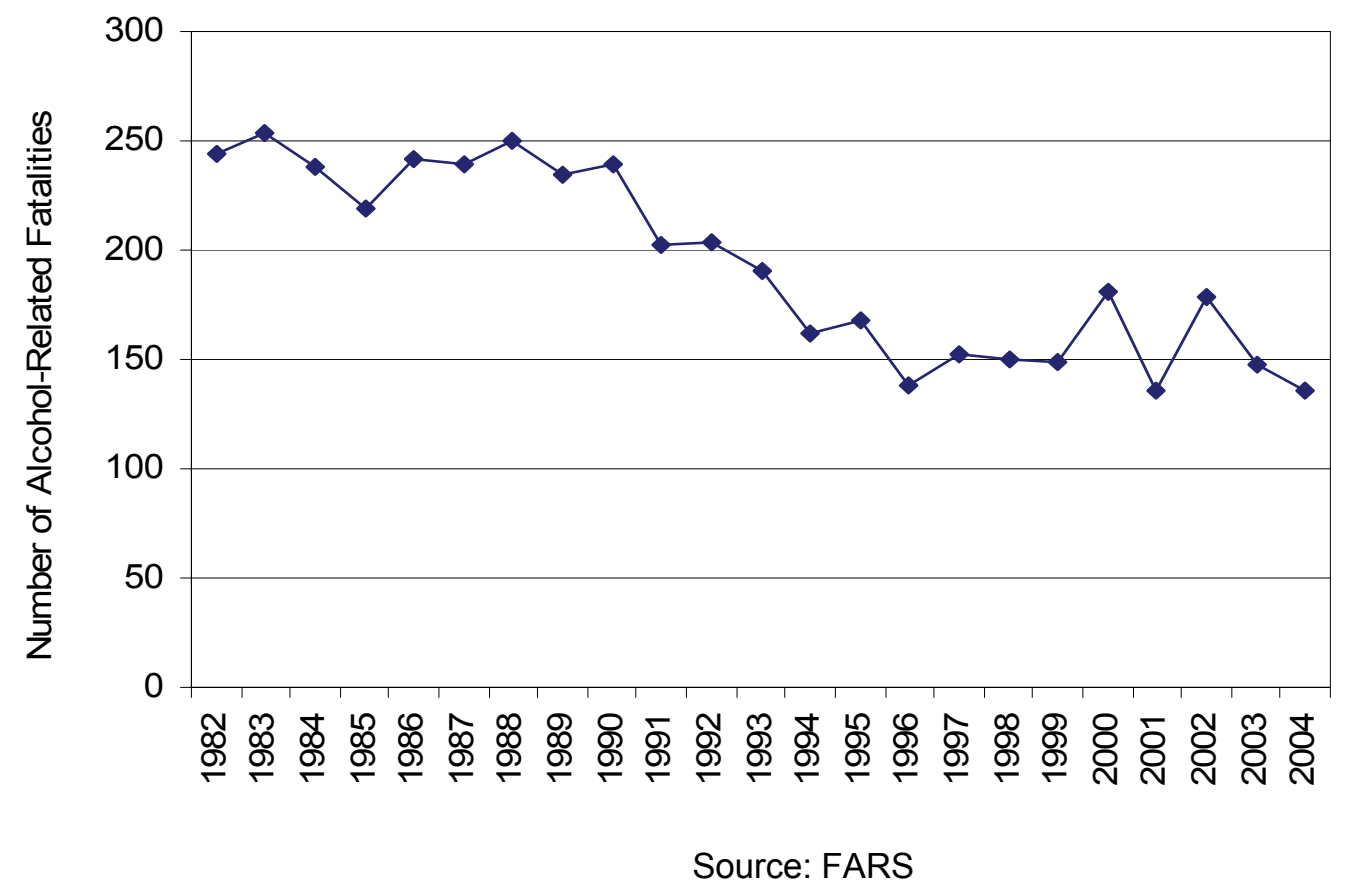

In 2002, West Virginia became a Strategic Evaluation State. The 13 SES were selected because they had either high numbers of alcohol-related fatalities or higher than average rates of alcohol-related fatalities and made a commitment to participate in the program. West Virginia and the other Strategic Evaluation States committed to conduct highly visible enforcement efforts during key holiday crackdown periods and to conduct sustained enforcement between holiday crackdowns. The 12 other States were Alaska, Arizona, California, Florida, Georgia, Louisiana, Mississippi, Montana, New Mexico, Ohio, Pennsylvania, and Texas. In 2005, Missouri and South Carolina joined the group to bring the number of SES States to 15.

NHTSA's impaired driving high-visibility enforcement model involved three components: (1) DWI enforcement, 2) paid media and public awareness, and 3) evaluation. The enforcement component involved two crackdowns and sustained enforcement during the remainder of the year. Each crackdown was to cover 85 percent of the States' populations and involve sobriety checkpoints or saturation patrols. Public awareness efforts were to involve State earned media, possible State-funded paid media and NHTSA-funded paid media that emphasized a strong enforcement message. 


\section{A. Crackdowns}

For 2003, the first paid and earned media campaign and enforcement crackdown was scheduled around the July $4^{\text {th }}$ holiday. The paid media campaign aired on the three weekends before, on, and after the July $4^{\text {th }}$ holiday weekend. High-visibility enforcement was focused on the 17 consecutive nights surrounding the same three weekends beginning on Friday, June 27, 2003, and ending on Sunday, July 13, 2003. Sustained enforcement continued throughout the year and was accompanied by a second crackdown focused on the period from Thanksgiving through New Year's Day. Beginning in 2004, the first crackdown was moved from the July $4^{\text {th }}$ weekend to Labor Day weekend. Thus, the paid media aired on the three weekends before, on, and after the Labor Day weekend. High-visibility enforcement was focused on 17 consecutive nights which began on Friday, August 27, 2004, and ended on Sunday, September 12, 2004. For 2005, paid media and enhanced enforcement efforts focused again around the 17 consecutive nights surrounding the Labor Day holiday from August 17, 2005, through September 5, 2005.

\section{B. Sobriety Checkpoints}

Highly visible, well-publicized enforcement has been demonstrated to be the most effective method to reduce drinking and driving and alcohol-related fatal crashes. Sobriety checkpoints represent the most visible method for enforcing drinking and driving laws (driving while intoxicated [DWI]) in West Virginia. Research has demonstrated that highly visible enforcement efforts involving many sobriety checkpoints and a strong enforcement-based media message significantly reduce drinking and driving and alcohol-related fatal crashes both on a local level (Wells, Preusser, \& Williams, 1991) and statewide level (Lacey, Jones, \& Smith, 1999; Zwicker et al.,2007).

The U.S. Supreme Court in 1990 (Michigan v. Sitz) ruled that sobriety checkpoints do not violate the Constitution's fourth amendment provision banning unreasonable searches and seizures and indicated in its ruling that the public interest in reducing alcohol-impaired driving was sufficient to justify the brief intrusion of a sobriety checkpoint. Currently, sobriety checkpoints are permissible in 12 of the 15 Strategic Evaluation States. Alaska, Montana, and Texas do not conduct sobriety checkpoints.

West Virginia focused its high-visibility enforcement efforts on conducting many sobriety checkpoints particularly in targeted counties. West Virginia conducted fully staffed sobriety checkpoints in six targeted counties. In addition, as part of its effort to conduct sobriety checkpoints in areas with fewer law enforcement personnel, the State included low-manpower sobriety checkpoints with as few as three or four officers. A recent study of weekly low-manpower checkpoints in two West Virginia counties showed a significant reduction in the 
percentage of drinking drivers at night with blood alcohol concentrations at or above 05 grams per deciliter (Lacey, Ferguson, Kelley-Baker, \& Rider, 2005). Low-manpower sobriety checkpoints enabled law enforcement agencies in rural areas with few resources to conduct high-visibility enforcement.

\section{STRATEGIC EVALUATION STATE PROGRAM DESCRIPTION}

\section{A. Paid Media}

The 2003 impaired driving high-visibility enforcement campaign included a large-scale NHTSA-funded paid media advertising campaign. Of the $\$ 11$ million appropriated for the national paid media buy, $\$ 500,000$ was spent to produce a TV spot, $\$ 5.5$ million was spent to purchase airtime on national TV, and $\$ 5$ million purchased airtime on TV in the 13 SES States. West Virginia's share of this was $\$ 101,244$ for 576 media spots that ran during the June 20 - July 13, 2003, period (Levy et al., 2004). West Virginia also spent $\$ 48,000$ in State funds on paid media to support the winter holiday crackdown in December 2003.

In 2004, a budget of $\$ 9$ million was allocated for paid media to support the nationwide You Drink \& Drive You Lose crackdown and an additional \$5 million was allocated for the SES. West Virginia's share of the SES allocation was $\$ 115,594$ and the State provided an additional $\$ 50,000$ for a total paid media buy of $\$ 165,594$ to support the Labor Day Crackdown in 2004.

In 2005, a budget of $\$ 10$ million was allocated for paid media to support the You Drink \& Drive You Lose crackdown and an additional \$3.8 million was allocated for the SES. West Virginia's share of the SES allocation was $\$ 150,316$ to support the Labor Day Crackdown in 2005. From 2003 through 2005, \$416,838 was spent on media to support high-visibility impaired driving crackdowns.

The TV ad targeted young men 21 to 34 years old and ran on TV programs often viewed by this age group. The objective of the message was to generate high awareness of stepped-up enforcement efforts, checkpoints and crackdowns; and concurrently increase the perception that the risk of getting arrested is too high to take a chance on driving impaired.

\section{B. Enforcement}

Beginning in June 2003, West Virginia held a reported total of 810 enforcement activities (i.e., sobriety checkpoints and saturation patrols) in the 6 targeted counties from 2003 through 2005 . The total enforcement averaged 101.67 activities for each targeted county across the three-year period reported here. There were also reportedly a total of 3,142 enforcement activities for the same period in the 49 non-targeted counties. The total 
enforcement for non-targeted counties averaged 64.12 activities per each county during the same two-and-a-halfyear period. Reporting of enforcement activities improved between 2003 and 2005, which may explain the disparity in the totals for both saturation patrols and sobriety checkpoints in 2003 compared to both 2004 and 2005. However, reporting alone is unlikely to account for the entire increase in the number of both types of enforcement activities. Overall, there were many more checkpoints and saturation patrols for each targeted county over the course of the campaign than for the non-targeted counties.

Table 1. Average Number of DWI Enforcement Activities Held in Each Targeted and Non-Targeted County by Year

\begin{tabular}{lllcccc}
\hline & & Enforcement Type & $\begin{array}{c}\mathbf{2 0 0 3} \\
(\text { Mean) }\end{array}$ & $\begin{array}{c}\mathbf{2 0 0 4} \\
(\text { Mean) }\end{array}$ & $\begin{array}{c}\mathbf{2 0 0 5} \\
(\text { Mean) }\end{array}$ & Totals \\
\hline Six Targeted Counties & $(\mathrm{N}=6)$ & Sobriety Checkpoints & 2.33 & 6.67 & 10.67 & $\mathrm{~N}=118$ \\
& & Saturation Patrols & 5.67 & 37.83 & 71.67 & $\mathrm{~N}=692$ \\
\multirow{2}{*}{ Non-Targeted Counties } & \multirow{2}{*}{$(\mathrm{N}=49)$} & Sobriety Checkpoints & 0.20 & 4.22 & 6.92 & $\mathrm{~N}=556$ \\
& & Saturation Patrols & 1.06 & 21.08 & 30.63 & $\mathrm{~N}=2586$ \\
\hline
\end{tabular}

\section{Enforcement Funding}

The enforcement funds spent by the State totaled $\$ 870,316$ for $2003, \$ 1,021,421$ for 2004 , and $\$ 1,051,864$ for 2005. The total enforcement funds include money received by law enforcement from the West Virginia Commission on Drunk Driving Prevention. That agency contributed \$565,335 in 2003 for enforcement, \$599,585 in 2004, and $\$ 409,792$ in 2005. About $\$ 250,000$ of the commission's 2004 funds and an additional $\$ 490,000$ from the State were spent to replace all breath testing machines in the State and train all officers on the new intoximeters. Thus, although the State provided $\$ 1,161,836$ in total funding for enforcement in 2004, $\$ 490,000$ of the funds were spent on the intoximeters. West Virginia spent about 54 cents per resident in 2003, 66 cents per resident in 2004, and 66 cents per resident in 2005. In total, the State spent \$3,360,439 from 2003 through 2005, or about 62 cents per resident on average each year on its publicity and enforcement campaign to combat drinking and driving.

\section{PROGRAM EVALUATION}

West Virginia began its paid media and enforcement campaign in late June 2003. In 2004, the State increased the level of enforcement efforts in six targeted counties beginning in the spring and continuing through the end of the year. The State again increased the number of checkpoints in targeted counties in the spring of 2005 that continued through the 17 consecutive days of paid media and enforcement surrounding the Labor Day holiday period from August 17 through September 5, 2005. This evaluation focused on the period beginning with July 2003 through September 2005. The six targeted counties were: Berkeley (Martinsburg), Ohio (Wheeling), Kanawha (Charleston), Marion (Fairmont), Raleigh (Beckley), and Wood (Parkersburg). 


\section{A. West Virginia Department of Motor Vehicle Office Surveys}

Department of Motor Vehicle offices were selected to represent all areas of the State. DMV offices in four of the six targeted counties were included. Targeted counties and city offices within the counties were Berkeley County (Martinsburg), Kanawha County (Charleston and Kanawha City), Raleigh County (Beckley), and Wood County (Parkersburg). DMV surveys were also conducted at offices in one or more towns for seven non-targeted counties, including Cabell (Huntington), Logan (Logan), Marshall (Moundsville), Mercer (Princeton), Putnam (Teays Valley and Winfield), Harrison (Bridgeport and Clarksburg), and Monongalia (Morgantown). State

Highway Safety Offices conducted at DMV surveys at 9 offices before, during, and after the July $4^{\text {th }}$ holiday period for 2003. For 2004, DMV surveys were conducted at 10 offices in May, June, August, and September. For 2005, follow-up DMV surveys were conducted at 10 offices in April, August, and September. In total, there were 10 different administrations of the DMV surveys from June 2003 through September 2005. Some DMV offices in counties were replaced with nearby towns in the same county because of low return rates. Logan County (Logan), a non-targeted county, was dropped because of low return rates and replaced with Monongalia County (Morgantown). An example of the DMV office survey is located in Appendix A.

\section{B. West Virginia Roadside Survey Direct Measures of Driver BACs}

Driver BACs were collected at sobriety checkpoints in six towns. Sobriety checkpoints were held once each month on average from April 2004 through November 2004, and again from April 2005 through June 2005. The roadside surveys served as a direct measure of the effect of enforcement and publicity on drinking and driving. Towns in the targeted counties were selected. The towns were Beckley (Raleigh County), Charleston (Kanawha County), Fairmont (Marion County), Martinsburg (Berkeley County), Parkersburg (Wood County), and Wheeling (Ohio County). Sobriety checkpoints were held on average once each month including the months before and after each holiday crackdown at the same location, road, night of the week, and at the same time of night. An example of the roadside survey data collection form is located in Appendix B.

At sobriety checkpoints, the research team obtained voluntary, "blind," anonymous BACs from randomly selected drivers on handheld breath testing devices. These devices (Intoxilyzer 400PA) stored, but did not display the driver's BAC reading. The research team collected anonymous BAC information from the random sample of drivers who were passing through the sobriety checkpoint in one direction in cases where traffic flowed in both directions and the sobriety checkpoint was held on both sides of a road. Researchers collected this data after the drivers had passed through the sobriety checkpoint. Researchers interviewed between 100 and 250 drivers at each sobriety checkpoint, typically about 20 percent of the traffic passing in one direction at a sobriety checkpoint. The unstructured interviews consisted of a short set of questions about the type of location the driver was coming from 
and going to, whether the driver had been through a sobriety checkpoint in the past month, opinions of sobriety checkpoints, and whether the driver had heard any media messages about special efforts to enforce the laws against drinking and driving. Researchers estimated characteristics such as age group, gender, race, number of passengers, and type of vehicle after completing an interview with a driver. Generally, about 96 percent or more drivers agreed to the BAC test. The team collected 3,202 BAC samples from drivers in the course of data collection from late March through November of 2004 and 993 BAC samples from drivers over the course of data collection from April through June of 2005 (see also Zwicker et al., 2007, for a more complete description of this procedure).

\section{Alcohol-Related Fatalities}

Alcohol-related fatality data for the six targeted counties and the entire State were obtained from NHTSA's Fatality Analysis Reporting System for 2000 through the preliminary 2004 data. Crashes involving pedalcyclists and pedestrians were included because they are considered active road users and could have been fatally injured by drinking drivers. The alcohol-related fatality trends for the State and for the targeted counties were analyzed using an interrupted time series design. A separate interrupted-time series analysis was used to analyze the alcoholrelated fatality trend for men age 21 to 34 because they were the focus of the media efforts to increase awareness of the enforcement.

The ARIMA method was used to determine whether there was a change in the number of alcohol-related fatalities starting at a point in time coincident with the beginning of the first campaign crackdown in July of 2003 and sustained through December 31,2004. ARIMA modeling required the selection of a model that controlled for periodic fluctuations in the data series. That is, combinations of parameters were entered into the analysis such that systematic fluctuations in the data (i.e., monthly "lags") were reduced to non-significance. Lags were judged to be non-significant based on exploration of autocorrelations (AC) and partial-autocorrelations (PAC) where the monthly lags were deemed to be random with 95 percent confidence. The parameters used to control the lags, as required, significantly affected the series in order to be considered valid for inclusion in the model. Analyses were conducted using the "Trends" module of the software package SPSS 11.5.

The ARIMA modeling process applies parameters to account for periodic fluctuations in monthly alcoholrelated fatalities. For instance, alcohol-related fatalities tend to increase sharply over the summer months. There is also the possibility of non-periodic fluctuations that might occur due to random noise or simply different numbers of weekend days (when drinking and driving are more prevalent) in a given month. The modeling process accounts for these periodic variations in the series by including the appropriate parameter. Additionally, multivariate ARIMA models, like the one used in this study for analyzing all alcohol-related fatalities, allow for the addition of a "covariate" which examines change in a series in the context of changes in a similar comparison series. For instance, drinking and driving fatalities can be affected by the weather, economic conditions, statewide trends in 
drinking and driving, and regionwide efforts to combat drinking and driving. The covariate used here for analyzing all alcohol-related fatalities for the entire State of West Virginia was the combined total alcohol-related fatalities each month for all contiguous counties from the five surrounding States: Kentucky, Maryland, Ohio, Pennsylvania, and Virginia. The 4 Maryland counties were: Allegany, Frederick, Garrett, and Washington. The 9 Ohio counties were: Athens, Belmont, Columbiana, Gallia, Jefferson, Lawrence, Meigs, Monroe, and Washington. The 4 Pennsylvania counties were: Beaver, Fayette, Greene, and Washington. The 4 Kentucky counties were: Boyd, Lawrence, Martin, and Pike. The 13 Virginia counties were: Alleghany, Augusta, Bath, Bland, Buchanan, Clarke, Craig, Giles, Highland, Loudon, Rockingham, Shenandoah, and Tazewell.

\section{West Virginia Telephone Surveys}

In 2003, 2004 and 2005, NHTSA conducted statewide telephone surveys on drinking and driving before and after each impaired driving crackdown in West Virginia. NHTSA collected baseline measurements of awareness, behavior, and perceptions regarding public information and enforcement programs focused on deterring drinking and driving. Following this, West Virginia conducted its crackdown, which included an increased enforcement effort of drinking and driving laws, supported by a communications campaign that consisted of paid advertisements and earned media. Finally, NHTSA administered a second set of surveys to determine the impact of each crackdown's public education and enforcement efforts.

\begin{tabular}{|c|c|c|c|}
\hline \multirow{2}{*}{ Interviewing Wave } & \multicolumn{2}{|c|}{ Sample Size } & \multirow{2}{*}{ Dates of Interviewing } \\
\hline & $\begin{array}{c}\text { All } \\
\text { Drivers }\end{array}$ & 18-34 & \\
\hline 2003 Pre-Crackdown & 500 & 147 & May 29 - June 16, 2003 \\
\hline 2003 Post-Crackdown & 501 & 144 & July 14 - August 5, 2003 \\
\hline 2004 Pre-Crackdown & 500 & 128 & August $4-26,2004$ \\
\hline 2004 Post-Crackdown & 500 & 143 & September 13 - October 14, 2004 \\
\hline 2005 Pre-Crackdown & 500 & 124 & July 21 - August 27, 2005 \\
\hline 2005 Post-Crackdown & 500 & 120 & September 14 - October 10,2005 \\
\hline
\end{tabular}

Schulman, Ronca, \& Bucuvalas, Inc., a national survey research organization, collected data from drivers in the following counties: Berkeley, Cabell, Harrison, Kanawha, Marion, Mercer, Monongalia, Ohio, Raleigh, and Wood.

The initial respondent selection procedure for the 2003 pre-crackdown survey wave asked for the "youngest driver" in the household. Midway through the field period the respondent selection procedure was changed to ask for the "youngest male driver" in order to increase the number of young males in the sample. In the 
2003 post-crackdown survey wave and all subsequent waves, the selection procedure asked for the "youngest male driver" throughout the field period. The 2003 pre-crackdown survey wave data was weighted to match the distribution of gender (male/female) and age (18-34/35+) of the 2003 post-crackdown survey wave under the assumption that the 2003 post-crackdown survey wave was conducted consistently.

The survey questionnaire was programmed on a computer-assisted telephone interviewing system (CATI). Up to five callbacks were made to determine if randomly generated phone numbers were household numbers, and up to eight callbacks were made to find a respondent in a household. A Spanish version of the questionnaire was also used. Unless otherwise noted, all data for the 2003 pre-crackdown survey wave is weighted. The number of unweighted cases is also reported on all figures. A standard chi-square differences in proportions test was used in testing for statistical differences between pre- and post-crackdown survey waves. Differences in proportions were judged to be significant at the 95 percent level of confidence.

\section{RESULTS AND DISCUSSION}

\section{West Virginia Department of Motor Vehicles Survey}

\section{A. Characteristics of DMV Survey Respondents}

There were 10 administrations of the DMV surveys, including surveys both before and after the July $4^{\text {th }}$ 2003 holiday crackdown as well as the Labor Day 2004 and 2005 holiday crackdowns. The race and age groups of survey respondents for each survey are presented below in Tables 2, 3, and 4. As indicated in Table 2, the proportion of men and women responding to the survey was slightly skewed towards women, with an average of 52.1 percent across all 10 surveys as compared to an average of 47.9 percent for men. As shown in Table 3 , the proportion of respondents identifying themselves in each age group was somewhat similar, but generally higher than their proportions in the population of the State. Drivers identifying themselves as 21 to 39 years old were overrepresented by 8.7 percentage points across all surveys, comprising an average of 39.8 percent of the survey respondents while making up just 31.1 percent of the driving age group population. However, those 60 and older were underrepresented, averaging just 12.0 percent across all surveys as compared to their composition of nearly 25 percent of the driving age population. Table 4 shows the percentage of respondents identifying themselves as White, Black, or Asian in each survey. Asians were somewhat higher than their proportion in the State's population estimates. The proportion of respondents identifying themselves as Black and Native American was somewhat lower and the proportion identifying themselves as White was somewhat higher than their overall representation in the population. Overall, the proportions were generally similar to the population estimates. 
Table 2. West Virginia DMV Survey Q1: Self-Reported Gender by Survey Administration

\begin{tabular}{|c|c|c|c|c|c|c|c|c|c|c|c|}
\hline $\begin{array}{c}\text { Self- } \\
\text { Reported } \\
\text { Gender }\end{array}$ & $\begin{array}{c}\text { Jun } \\
2003 \\
\text { Pre } \\
(\%)\end{array}$ & $\begin{array}{c}\text { Jun } \\
2003 \\
\text { Mid } \\
(\%)\end{array}$ & $\begin{array}{l}\text { July } \\
2003 \\
\text { Post } \\
(\%)\end{array}$ & $\begin{array}{l}\text { Apr } \\
2004 \\
(\%)\end{array}$ & $\begin{array}{c}\text { May } \\
2004 \\
(\%)\end{array}$ & $\begin{array}{c}\text { Jun } \\
2004 \\
(\%)\end{array}$ & $\begin{array}{c}\text { Aug } \\
2004 \\
\text { Pre } \\
(\%)\end{array}$ & $\begin{array}{l}\text { Sept } \\
2004 \\
\text { Post } \\
(\%)\end{array}$ & $\begin{array}{c}\text { May } \\
2005 \\
(\%)\end{array}$ & $\begin{array}{c}\text { Jun } \\
2005 \\
(\%)\end{array}$ & $\begin{array}{c}\text { WV } \\
\text { Population } \\
\text { Statistics* } \\
(\%)\end{array}$ \\
\hline $\mathrm{N}=$ & 644 & 827 & 672 & 1,881 & 1,970 & 1,696 & 1,621 & 1,893 & 1,917 & 1,906 & $1,808,344$ \\
\hline Men & 54.2 & 46.8 & 46.3 & 48.6 & 46.7 & 45.1 & 44.8 & 51.2 & 49.7 & 45.6 & 48.6 \\
\hline Women & 45.8 & 53.2 & 53.7 & 51.4 & 53.3 & 54.9 & 55.2 & 48.8 & 50.3 & 54.4 & 51.4 \\
\hline Total & 100 & 100 & 100 & 100 & 100 & 100 & 100 & 100 & 100 & 100 & 100 \\
\hline
\end{tabular}

Table 3. West Virginia DMV Survey Q2: Self-Reported Age Group by Survey Administration

\begin{tabular}{|c|c|c|c|c|c|c|c|c|c|c|c|}
\hline $\begin{array}{c}\text { Self- } \\
\text { Reported } \\
\text { Age Group }\end{array}$ & $\begin{array}{c}\text { Jun } \\
2003 \\
\text { Pre } \\
(\%)\end{array}$ & $\begin{array}{l}\text { Jun } \\
2003 \\
\text { Mid } \\
\text { (\%) }\end{array}$ & $\begin{array}{l}\text { July } \\
2003 \\
\text { Post } \\
(\%)\end{array}$ & $\begin{array}{c}\text { Apr } \\
2004 \\
(\%)\end{array}$ & $\begin{array}{l}\text { May } \\
2004 \\
(\%)\end{array}$ & $\begin{array}{c}\text { Jun } \\
\text { 2004 } \\
(\%)\end{array}$ & $\begin{array}{c}\text { Aug } \\
2004 \\
\text { Pre } \\
(\%)\end{array}$ & $\begin{array}{l}\text { Sept } \\
2004 \\
\text { Post } \\
(\%)\end{array}$ & $\begin{array}{c}\text { May } \\
2005 \\
(\%)\end{array}$ & $\begin{array}{c}\text { Jun } \\
2005 \\
(\%)\end{array}$ & $\begin{array}{c}\text { WV } \\
\text { Population } \\
\text { Statistics* } \\
(\%)\end{array}$ \\
\hline $\mathrm{N}=$ & 644 & 827 & 675 & 1,879 & 1,979 & 1,696 & 1,619 & 1,888 & 1,916 & 1,901 & $1,455,370$ \\
\hline $16-20$ & 8.1 & 10.5 & 11.7 & 11.1 & 11.9 & 10.9 & 8.8 & 8.2 & 10.2 & 5.9 & 8.8 \\
\hline $21-39$ & 41.0 & 37.0 & 35.9 & 40.8 & 45.4 & 44.8 & 42.4 & 38.9 & 34.3 & 37.8 & 31.1 \\
\hline $40-49$ & 21.0 & 23.2 & 23.9 & 21.3 & 20.3 & 21.1 & 20.3 & 22.0 & 21.5 & 21.6 & 19.5 \\
\hline $50-59$ & 19.1 & 17.7 & 18.2 & 14.8 & 14.2 & 14.0 & 14.7 & 17.3 & 19.9 & 18.6 & 15.7 \\
\hline $60+$ & 10.9 & 11.5 & 10.4 & 12.0 & 8.2 & 9.2 & 13.8 & 13.7 & 14.2 & 16.1 & 24.9 \\
\hline Total & 100 & 100 & 100 & 100 & 100 & 100 & 100 & 100 & 100 & 100 & 100 \\
\hline
\end{tabular}

* 2000 U.S. Census

Table 4. West Virginia DMV Survey Q3: Self-Reported Race by Survey Administration

\begin{tabular}{|c|c|c|c|c|c|c|c|c|c|c|c|}
\hline $\begin{array}{c}\text { Self- } \\
\text { Reported } \\
\text { Race }\end{array}$ & $\begin{array}{c}\text { Jun } \\
2003 \\
\text { Pre } \\
(\%)\end{array}$ & $\begin{array}{l}\text { Jun } \\
2003 \\
\text { Mid } \\
(\%)\end{array}$ & $\begin{array}{l}\text { July } \\
2003 \\
\text { Post } \\
(\%)\end{array}$ & $\begin{array}{c}\text { Apr } \\
2004 \\
(\%)\end{array}$ & $\begin{array}{l}\text { May } \\
2004 \\
(\%)\end{array}$ & $\begin{array}{c}\text { Jun } \\
2004 \\
(\%)\end{array}$ & $\begin{array}{c}\text { Aug } \\
2004 \\
\text { Pre } \\
(\%)\end{array}$ & $\begin{array}{l}\text { Sept } \\
2004 \\
\text { Post } \\
(\%)\end{array}$ & $\begin{array}{l}\text { May } \\
2005 \\
(\%)\end{array}$ & $\begin{array}{c}\text { Jun } \\
2005 \\
(\%)\end{array}$ & $\begin{array}{c}\text { WV } \\
\text { Population } \\
\text { Statistics* } \\
(\%)\end{array}$ \\
\hline $\mathrm{N}=$ & 643 & 821 & 662 & 1,866 & 1,968 & 1,687 & 1,604 & 1,886 & 1,914 & 1,889 & \\
\hline White & 92.7 & 91.7 & 91.5 & 90.2 & 91.1 & 90.5 & 87.8 & 91.8 & 93.4 & 92.3 & 95.0 \\
\hline Black & 4.5 & 4.9 & 4.7 & 6.4 & 6.6 & 5.9 & 8.0 & 4.9 & 4.2 & 5.8 & 3.4 \\
\hline Asian & 1.9 & 1.5 & 1.4 & 1.3 & 1.1 & 1.5 & 1.8 & 1.2 & 0.7 & 0.7 & 0.7 \\
\hline $\begin{array}{l}\text { Native } \\
\text { American }\end{array}$ & 0.6 & 1.2 & 1.7 & 1.1 & 0.5 & 1.5 & 1.1 & 1.2 & 0.8 & 0.3 & 0.6 \\
\hline Other & 0.3 & 0.7 & 0.8 & 1.0 & 0.8 & 0.6 & 1.2 & 0.8 & 0.9 & 0.8 & 0.4 \\
\hline Total & 100 & 100 & 100 & 100 & 100 & 100 & 100 & 100 & 100 & 100 & 100 \\
\hline
\end{tabular}

\section{B. Exposure to Enforcement Message}

Significantly more respondents in the targeted counties reported seeing or hearing something about alcoholimpaired driving in West Virginia after each holiday period compared to those responding before each holiday 
period. As shown in Table 5, there was a 29.7 percentage point increase from the June 2003 pre-July $4^{\text {th }}$ holiday

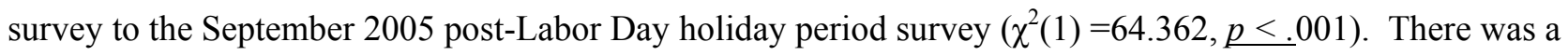
similarly large increase of 31 percentage points between the pre- and post-July $4^{\text {th }}$ holiday surveys for $2003\left(\chi^{2}(1)\right.$

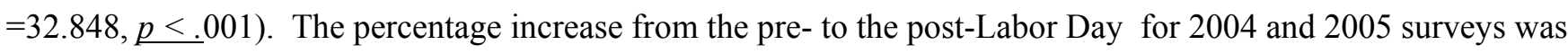
progressively smaller each year at 6.7 percent $\left(\chi^{2}(1)=7.826, \underline{p<.01)}\right.$ and 5.8 percent $\left(\chi^{2}(1)=7.094, p<.01\right)$ respectively, but both increases were significant. There was no significant increase from the first to the last survey administered for non-targeted counties in reports of seeing or hearing something $\left(\chi^{2}(1)=0.031, p=.859\right)$.

However, the baseline rate of 67 percent in non-targeted counties having seen or heard something was much higher than the 44 percent reported in targeted counties. There was a smaller, 10.6-percentage-point increase between the pre- and post-July $4^{\text {th }} 2003$ surveys for those in the non-targeted counties $\left(\chi^{2}(1)=13.610, p<.001\right)$ and a similar, smaller but significant 4.7-percentage-point increase between the pre- and post-Labor Day 2005 surveys for the non-targeted counties $\left(\chi^{2}(1)=4.792, \mathrm{p}=.029\right)$. The increase for targeted counties for the July $4^{\text {th }}$ holiday period of 2003 was 20.1 percentage points higher than the increase for the non-targeted counties over the course of the three crackdowns. Overall, the increases during holiday periods were much larger for the targeted counties as compared to the non-targeted counties. In addition, there was no overall increase in awareness from the first to the last survey for non-targeted counties while there was a large increase for targeted counties.

\begin{tabular}{|c|c|c|c|c|c|c|c|c|c|c|c|}
\hline Targeted Counties & & $\begin{array}{c}\text { Jun } \\
2003 \\
\text { Pre } \\
\text { (\%) }\end{array}$ & $\begin{array}{c}\text { Jun } \\
2003 \\
\text { Mid } \\
\text { (\%) }\end{array}$ & $\begin{array}{l}\text { July } \\
2003 \\
\text { Post } \\
\text { (\%) }\end{array}$ & $\begin{array}{c}\text { May } \\
2004 \\
(\%)\end{array}$ & $\begin{array}{c}\text { Jun } \\
2004 \\
(\%)\end{array}$ & $\begin{array}{c}\text { Aug } \\
2004 \\
\text { Pre } \\
\text { (\%) }\end{array}$ & $\begin{array}{l}\text { Sept } \\
2004 \\
\text { Post } \\
(\%)\end{array}$ & $\begin{array}{c}\text { Apr } \\
2005 \\
(\%)\end{array}$ & $\begin{array}{c}\text { Aug } \\
2005 \\
\text { Pre } \\
(\%)\end{array}$ & $\begin{array}{c}\text { Sep } \\
2005 \\
\text { Post } \\
(\%)\end{array}$ \\
\hline & $\mathrm{N}=$ & 193 & 220 & 148 & 976 & 977 & 712 & 668 & 908 & 898 & 892 \\
\hline Yes & & 44.0 & 65.9 & 75.0 & 65.6 & 68.6 & 68.7 & 75.4 & 62.8 & 67.9 & 73.7 \\
\hline No & & 56.0 & 34.1 & 25.0 & 34.4 & 31.4 & 31.3 & 24.6 & 37.2 & 32.1 & 26.3 \\
\hline & Total & 100 & 100 & 100 & 100 & 100 & 100 & 100 & 100 & 100 & 100 \\
\hline \multicolumn{12}{|c|}{ Non-Targeted Counties } \\
\hline & $\mathrm{N}=$ & 445 & 598 & 522 & 884 & 972 & 956 & 922 & 947 & 992 & 981 \\
\hline Yes & & 67.4 & 67.2 & 78.0 & 66.7 & 64.1 & 68.1 & 67.1 & 56.4 & 63.2 & 67.9 \\
\hline No & & 32.6 & 32.8 & 22.0 & 33.3 & 35.9 & 31.9 & 32.9 & 43.6 & 36.8 & 32.1 \\
\hline & Total & 100 & 100 & 100 & 100 & 100 & 100 & 100 & 100 & 100 & 100 \\
\hline
\end{tabular}

The media source most often cited by those in targeted counties who had seen or heard something was Television, averaging 45.7 percent (range $=28.4 \%-59.7 \%$ ) across all survey administrations. Newspapers were cited as the second most frequent source, average 27.8 percent (range $=21.0 \%-41.4 \%$ ) of all respondents who reported seeing something. Of those who indicated seeing something, a Sobriety Checkpoint was the least frequently cited named source $(M=7.9 \%)$, with the exception of Other as a source $(M=6.3 \%)$. The pattern for the non-targeted counties was the same. Results are presented in Table 6. 
Table 6. West Virginia DMV Office Survey Q13: Source if Yes to Recently Seen or Heard Something About Alcohol Impaired Driving (or Drunk Driving) for Targeted and Non-Targeted Counties

\begin{tabular}{|c|c|c|c|c|c|c|c|c|c|c|}
\hline Targeted Counties* & $\begin{array}{c}\text { Jun } \\
2003 \\
\text { Pre } \\
(\%)\end{array}$ & $\begin{array}{c}\text { Jun } \\
2003 \\
\text { Mid } \\
(\%)\end{array}$ & $\begin{array}{c}\text { July } \\
2003 \\
\text { Post } \\
(\%)\end{array}$ & $\begin{array}{c}\text { May } \\
2004 \\
(\%)\end{array}$ & $\begin{array}{c}\text { Jun } \\
2004 \\
(\%)\end{array}$ & $\begin{array}{c}\text { Aug } \\
2004 \\
\text { Pre } \\
(\%)\end{array}$ & $\begin{array}{l}\text { Sept } \\
2004 \\
\text { Post } \\
(\%)\end{array}$ & $\begin{array}{c}\text { Apr } \\
2005 \\
(\%)\end{array}$ & $\begin{array}{c}\text { Aug } \\
2005 \\
\text { Pre } \\
(\%)\end{array}$ & $\begin{array}{c}\text { Sep } \\
2005 \\
\text { Post } \\
(\%)\end{array}$ \\
\hline $\mathrm{N}=$ & 194 & 224 & 148 & 995 & 999 & 493 & 504 & 943 & 915 & 911 \\
\hline Newspaper & 22.2 & 21.0 & 25.0 & 24.4 & 22.4 & 41.4 & 36.5 & 26.1 & 28.6 & 30.1 \\
\hline Radio & 11.9 & 14.3 & 19.6 & 16.5 & 20.0 & 33.1 & 35.6 & 15.9 & 19.1 & 18.9 \\
\hline Television & 28.4 & 46.4 & 45.3 & 43.3 & 40.5 & 59.7 & 55.8 & 37.2 & 48.1 & 52.6 \\
\hline Poster & 8.8 & 6.7 & 11.5 & 10.7 & 12.7 & 23.4 & 17.7 & 10.1 & 8.3 & 10.1 \\
\hline Brochure & 2.1 & .9 & 2.0 & 2.7 & 3.7 & 11.0 & 13.3 & 4.5 & 4.9 & 2.9 \\
\hline Sobriety Checkpoint & 2.6 & 1.3 & 4.7 & 7.0 & 10.4 & 14.8 & 12.3 & 7.0 & 8.7 & 8.9 \\
\hline Other & 3.6 & 4.5 & 4.1 & 6.6 & 6.7 & 9.3 & 7.9 & 7.7 & 6.2 & 5.7 \\
\hline \multicolumn{11}{|l|}{ Non-Targeted Counties* } \\
\hline $\mathrm{N}=$ & 452 & 604 & 528 & 894 & 984 & 657 & 620 & 954 & 1,003 & 996 \\
\hline Newspaper & 26.3 & 20.5 & 31.4 & 25.8 & 24.2 & 36.7 & 32.1 & 26.4 & 29.6 & 25.9 \\
\hline Radio & 16.2 & 19.9 & 23.5 & 20.0 & 21.3 & 40.9 & 30.9 & 15.1 & 17.9 & 19.3 \\
\hline Television & 45.4 & 48.7 & 51.9 & 42.2 & 35.4 & 62.2 & 63.4 & 34.0 & 38.3 & 44.1 \\
\hline Poster & 16.6 & 14.2 & 13.3 & 9.4 & 10.9 & 16.7 & 18.6 & 8.8 & 9.2 & 8.3 \\
\hline Brochure & 3.5 & 4.1 & 4.0 & 3.1 & 4.0 & 7.7 & 5.3 & 3.6 & 2.6 & 3.1 \\
\hline Sobriety Checkpoint & 5.3 & 5.1 & 6.3 & 5.4 & 8.4 & 8.3 & 8.6 & 3.9 & 4.5 & 5.6 \\
\hline Other & 7.7 & 9.4 & 10.0 & 10.0 & 9.7 & 11.6 & 8.1 & 9.3 & 6.1 & 7.8 \\
\hline
\end{tabular}

*Respondent could indicate multiple sources.

The percentage of DMV survey respondents in the targeted counties able to identify the You Drink \& Drive. You Lose slogan increased 41.1 percentage points from 18.2 to 59.3 percent from the first June 2003 pre-July $4^{\text {th }}$ survey to the final September post-Labor Day 2005 survey $\left(\chi^{2}(1)=92.789, p<.001\right)$. There was a similar significant, but smaller 21.1-percentage-point increase in the non-targeted counties as well from 35.6 to 56.7

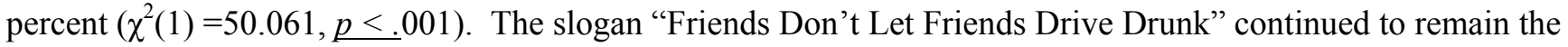
most frequently recognized slogan throughout the two-year campaign, averaging 84 percent for both the targeted and non-targeted counties across all survey administrations. Although West Virginia participates in NHTSA's Mid-Atlantic Regional Checkpoint Strikeforce campaign, recognition of the slogan Checkpoint Strikeforce in the targeted and non-targeted counties did not reach similar levels as the You Drink \& Drive. You Lose slogan. Results are presented in Table 7. 
Table 7. West Virginia DMV Office Survey Q14: Named One or More Alcohol Impaired Driving Slogans for Targeted and Non-Targeted Counties

\begin{tabular}{|c|c|c|c|c|c|c|c|c|c|c|}
\hline Targeted Counties* & $\begin{array}{c}\text { Jun } \\
2003 \\
\text { Pre } \\
(\%)\end{array}$ & $\begin{array}{c}\text { Jun } \\
2003 \\
\text { Mid } \\
(\%)\end{array}$ & $\begin{array}{c}\text { July } \\
2003 \\
\text { Post } \\
(\%)\end{array}$ & $\begin{array}{c}\text { May } \\
2004 \\
(\%)\end{array}$ & $\begin{array}{c}\text { Jun } \\
2004 \\
(\%)\end{array}$ & $\begin{array}{c}\text { Aug } \\
2004 \\
\text { Pre } \\
(\%)\end{array}$ & $\begin{array}{l}\text { Sept } \\
2004 \\
\text { Post } \\
(\%)\end{array}$ & $\begin{array}{c}\text { Apr } \\
2005 \\
(\%)\end{array}$ & $\begin{array}{c}\text { Aug } \\
2005 \\
\text { Pre } \\
(\%)\end{array}$ & $\begin{array}{c}\text { Sep } \\
2005 \\
\text { Post } \\
(\%)\end{array}$ \\
\hline $\mathrm{N}=$ & 165 & 193 & 120 & 889 & 859 & 618 & 595 & 784 & 767 & 799 \\
\hline $\begin{array}{l}\text { You Drink \& Drive. You } \\
\text { Lose }\end{array}$ & 18.2 & 31.6 & 41.7 & 40.4 & 35.2 & 40.1 & 56.5 & 40.6 & 43.5 & 59.3 \\
\hline Checkpoint Strikeforce & 18.8 & 11.9 & 20.0 & 16.0 & 20.6 & 29.1 & 28.4 & 19.6 & 17.6 & 15.8 \\
\hline $\begin{array}{l}\text { Friends Don't Let Friends } \\
\text { Drive Drunk }\end{array}$ & 97.0 & 91.2 & 62.5 & 92.4 & 89.3 & 80.9 & 76.0 & 85.2 & 83.4 & 83.1 \\
\hline $\begin{array}{l}\text { Step Away From the } \\
\text { Vehicle }\end{array}$ & 4.8 & 7.8 & 24.2 & 8.9 & 8.0 & 9.5 & 14.8 & 13.0 & 12.0 & 17.6 \\
\hline \multicolumn{11}{|l|}{ Non-Targeted Counties* } \\
\hline $\mathrm{N}=$ & 410 & 538 & 474 & 796 & 804 & 818 & 834 & 876 & 865 & 909 \\
\hline $\begin{array}{l}\text { You Drink \& Drive. You } \\
\text { Lose }\end{array}$ & 35.6 & 37.9 & 54.0 & 40.5 & 40.3 & 37.7 & 52.0 & 38.6 & 43.1 & 56.7 \\
\hline Checkpoint Strikeforce & 9.3 & 12.6 & 19.0 & 15.5 & 24.0 & 22.5 & 21.0 & 15.9 & 13.8 & 14.5 \\
\hline $\begin{array}{l}\text { Friends Don't Let Friends } \\
\text { Drive Drunk }\end{array}$ & 93.2 & 90.9 & 83.1 & 85.4 & 83.1 & 80.8 & 76.9 & 86.9 & 85.9 & 82.0 \\
\hline $\begin{array}{l}\text { Step Away From the } \\
\text { Vehicle }\end{array}$ & 6.6 & 8.2 & 16.0 & 11.9 & 7.2 & 8.1 & 18.1 & 11.5 & 7.2 & 11.0 \\
\hline
\end{tabular}

\section{Perceptions of Enforcement}

The proportion of DMV office survey respondents indicating that police "very strictly" enforce the drinking and driving laws increased significantly compared to the other response options combined from the first 2003 pre-July $4^{\text {th }}$ survey to the post-Labor Day 2005 survey $\left(\chi^{2}(1)=4.731, \underline{p}=.03\right)$. Only the July $4^{\text {th }} 2003$ crackdown resulted in a significant increase between the pre-and post-holiday crackdown responses in the targeted counties in those indicating that they thought police "very strictly" enforced the drinking and driving laws $\left(\chi^{2}(1)\right.$ $=8.702, \underline{p<.01)}$. There was no corresponding increase in non-targeted counties for the July $4^{\text {th }}$ crackdown. Neither the 2004 nor 2005 Labor Day crackdowns resulted in any significant changes in the proportion of those indicating that they thought police enforced the laws against drinking and driving "very strictly." Results are presented in Table 8 . 
Table 8. West Virginia DMV Office Survey Q10: Public Perception of the Strictness of Police Enforcement of Drinking and Driving Laws for Targeted and Non-Targeted Counties

\begin{tabular}{|c|c|c|c|c|c|c|c|c|c|c|c|}
\hline Targeted Counties & & $\begin{array}{c}\text { Jun } \\
2003 \\
\text { Pre } \\
(\%)\end{array}$ & $\begin{array}{c}\text { Jun } \\
2003 \\
\text { Mid } \\
(\%)\end{array}$ & $\begin{array}{c}\text { July } \\
2003 \\
\text { Post } \\
(\%)\end{array}$ & $\begin{array}{c}\text { May } \\
2004 \\
(\%)\end{array}$ & $\begin{array}{c}\text { Jun } \\
2004 \\
(\%)\end{array}$ & $\begin{array}{c}\text { Aug } \\
2004 \\
\text { Pre } \\
(\%)\end{array}$ & $\begin{array}{l}\text { Sept } \\
2004 \\
\text { Post } \\
(\%)\end{array}$ & $\begin{array}{c}\text { Apr } \\
2005 \\
(\%)\end{array}$ & $\begin{array}{c}\text { Aug } \\
2005 \\
\text { Pre } \\
(\%)\end{array}$ & $\begin{array}{c}\text { Sep } \\
2005 \\
\text { Post } \\
(\%)\end{array}$ \\
\hline & $\mathrm{N}=$ & 192 & 218 & 145 & 979 & 981 & 714 & 663 & 914 & 890 & 897 \\
\hline Very Strictly & & 21.4 & 22.5 & 35.9 & 37.1 & 31.5 & 31.8 & 31.2 & 29.2 & 31.8 & 29.1 \\
\hline Somewhat Strictly & & 47.4 & 43.6 & 42.1 & 43.0 & 50.2 & 48.2 & 45.4 & 43.3 & 45.4 & 48.3 \\
\hline Not Very Strictly & & 26.6 & 28.4 & 16.6 & 16.8 & 15.1 & 14.8 & 17.9 & 21.2 & 17.6 & 18.4 \\
\hline Rarely & & 3.1 & 5.0 & 5.5 & 2.2 & 2.8 & 4.5 & 3.6 & 4.2 & 3.8 & 3.2 \\
\hline Not At All & & 1.6 & 0.5 & 0.0 & 0.9 & 0.5 & 0.7 & 1.8 & 2.1 & 1.3 & 1.0 \\
\hline & Total & 100 & 100 & 100 & 100 & 100 & 100 & 100 & 100 & 100 & 100 \\
\hline \multicolumn{12}{|c|}{ Non-Targeted Counties } \\
\hline & $\mathrm{N}=$ & 447 & 595 & 522 & 884 & 974 & 950 & 912 & 938 & 984 & 981 \\
\hline Very Strictly & & 30.4 & 28.7 & 29.3 & 34.7 & 28.0 & 33.9 & 30.7 & 32.9 & 37.5 & 37.0 \\
\hline Somewhat Strictly & & 46.3 & 46.6 & 43.3 & 43.2 & 50.2 & 46.8 & 46.1 & 45.6 & 40.5 & 42.3 \\
\hline Not Very Strictly & & 18.3 & 22.0 & 21.1 & 16.6 & 17.0 & 14.8 & 15.7 & 16.7 & 16.1 & 17.2 \\
\hline Rarely & & 3.8 & 2.2 & 3.3 & 4.0 & 3.2 & 3.6 & 5.4 & 4.1 & 4.8 & 2.9 \\
\hline Not At All & & 1.1 & 0.5 & 3.1 & 1.5 & 1.5 & 0.8 & 2.2 & 0.6 & 1.1 & 0.6 \\
\hline & Total & 100 & 100 & 100 & 100 & 100 & 100 & 100 & 100 & 100 & 100 \\
\hline
\end{tabular}

The majority of drivers at targeted and non-targeted county DMV offices thought they were more likely to be arrested if they drove after drinking. As Table 9 indicates, this response did not change from the first survey in June 2003 to the last survey in September 2005. Furthermore, between the pre-and the post-DMV surveys for the July 4th 2003 holiday period, there was a significant 21.1 percentage increase in peoples' perceived likelihood of arrest for drinking and driving $(\chi 2(1)=20.586, p=.001)$. 
Table 9. West Virginia DMV Office Survey Q8: Perceived Likelihood of Getting Arrested if You Drove After Drinking for Targeted and Non-Targeted Counties

\begin{tabular}{|c|c|c|c|c|c|c|c|c|c|c|c|}
\hline Targeted Counties & & $\begin{array}{c}\text { Jun } \\
2003 \\
\text { Pre } \\
\text { (\%) }\end{array}$ & $\begin{array}{c}\text { Jun } \\
2003 \\
\text { Mid } \\
\text { (\%) }\end{array}$ & $\begin{array}{c}\text { July } \\
2003 \\
\text { Post } \\
(\%)\end{array}$ & $\begin{array}{l}\text { May } \\
2004 \\
(\%)\end{array}$ & $\begin{array}{c}\text { Jun } \\
2004 \\
(\%)\end{array}$ & $\begin{array}{c}\text { Aug } \\
2004 \\
\text { Pre } \\
\text { (\%) }\end{array}$ & $\begin{array}{l}\text { Sept } \\
2004 \\
\text { Post } \\
(\%)\end{array}$ & $\begin{array}{c}\text { Apr } \\
2005 \\
(\%)\end{array}$ & $\begin{array}{c}\text { Aug } \\
2005 \\
\text { Pre } \\
(\%)\end{array}$ & $\begin{array}{c}\text { Sep } \\
2005 \\
\text { Post } \\
(\%)\end{array}$ \\
\hline & $\mathrm{N}=$ & 186 & 216 & 145 & 962 & 977 & 714 & 660 & 912 & 881 & 884 \\
\hline Always & & 13.4 & 18.5 & 34.5 & 18.5 & 18.7 & 17.9 & 19.5 & 15.8 & 24.0 & 17.8 \\
\hline Nearly Always & & 19.4 & 17.6 & 22.8 & 27.4 & 27.1 & 29.6 & 26.2 & 20.5 & 24.9 & 23.2 \\
\hline Sometimes & & 41.9 & 41.7 & 27.6 & 37.5 & 39.4 & 34.9 & 36.5 & 39.3 & 31.9 & 40.2 \\
\hline Seldom & & 11.3 & 13.0 & 9.0 & 10.1 & 8.9 & 9.0 & 9.2 & 15.4 & 10.0 & 9.7 \\
\hline \multirow[t]{2}{*}{ Never } & & 14.0 & 9.3 & 6.2 & 6.4 & 5.8 & 8.7 & 8.5 & 9.1 & 9.3 & 9.2 \\
\hline & Total & 100 & 100 & 100 & 100 & 100 & 100 & 100 & 100 & 100 & 100 \\
\hline \multicolumn{12}{|c|}{ Non-Targeted Counties } \\
\hline & $\mathrm{N}=$ & 447 & 584 & 514 & 875 & 961 & 946 & 906 & 942 & 972 & 975 \\
\hline Always & & 20.6 & 16.8 & 23.7 & 17.1 & 17.2 & 17.9 & 18.4 & 15.8 & 24.3 & 22.9 \\
\hline Nearly Always & & 17.7 & 25.2 & 22.6 & 27.0 & 22.3 & 30.5 & 24.2 & 22.4 & 23.1 & 24.5 \\
\hline Sometimes & & 42.3 & 39.7 & 34.6 & 36.8 & 42.1 & 33.1 & 35.8 & 43.3 & 34.3 & 35.3 \\
\hline Seldom & & 12.1 & 11.1 & 11.7 & 9.9 & 12.0 & 10.1 & 12.6 & 10.0 & 8.8 & 9.6 \\
\hline \multirow[t]{2}{*}{ Never } & & 7.4 & 7.2 & 7.4 & 9.1 & 6.5 & 8.4 & 9.1 & 8.5 & 9.5 & 7.7 \\
\hline & Total & 100 & 100 & 100 & 100 & 100 & 100 & 100 & 100 & 100 & 100 \\
\hline
\end{tabular}

\section{Self-Reported Changes in Drinking and Driving}

The proportion of DMV office survey respondents indicating that they were drinking and driving more often compared to last year did not change significantly from the first to the last survey administration for either the targeted or non-targeted counties. The only crackdown that resulted in any significant change in self-reported drinking and driving for targeted counties was the Labor Day 2005 crackdown, which resulted in a significant decrease in self-reported drinking and driving compared to the previous 30 days $\left(\chi^{2}(1)=6.544, p<.02\right)$. No crackdown resulted in any significant change for the non-targeted counties. The trend for the non-targeted counties did not change significantly during any crackdown or overall during the course of the campaign. The results are shown in Table 10. 
Table 10. West Virginia DMV Office Survey Q9: Self-Reported Drinking and Driving Compared to Three Months Ago for Targeted and Non-Targeted Counties

\begin{tabular}{|c|c|c|c|c|c|c|c|c|c|c|c|}
\hline Targeted Counties & & $\begin{array}{c}\text { Jun } \\
2003 \\
\text { Pre } \\
\text { (\%) }\end{array}$ & $\begin{array}{c}\text { Jun } \\
2003 \\
\text { Mid } \\
\text { (\%) }\end{array}$ & $\begin{array}{c}\text { July } \\
2003 \\
\text { Post } \\
\text { (\%) }\end{array}$ & $\begin{array}{c}\text { May } \\
2004 \\
(\%)\end{array}$ & $\begin{array}{c}\text { Jun } \\
2004 \\
(\%)\end{array}$ & $\begin{array}{c}\text { Aug } \\
2004 \\
\text { Pre } \\
(\%)\end{array}$ & $\begin{array}{l}\text { Sept } \\
2004 \\
\text { Post } \\
(\%)\end{array}$ & $\begin{array}{c}\text { Apr } \\
2005 \\
(\%)\end{array}$ & $\begin{array}{c}\text { Aug } \\
2005 \\
\text { Pre } \\
(\%)\end{array}$ & $\begin{array}{c}\text { Sep } \\
2005 \\
\text { Post } \\
(\%)\end{array}$ \\
\hline & $\mathrm{N}=$ & 25 & 33 & 18 & 157 & 149 & 137 & 104 & 146 & 126 & 87 \\
\hline More Often & & 4.0 & 3.0 & 16.7 & 9.6 & 3.4 & 7.3 & 3.8 & 9.6 & 15.9 & 4.6 \\
\hline About the Same & & 48.0 & 78.8 & 38.9 & 49.0 & 51.0 & 54.0 & 49.0 & 51.4 & 50.8 & 65.5 \\
\hline Less Often & & 48.0 & 18.2 & 44.4 & 41.4 & 45.6 & 38.7 & 47.1 & 39.0 & 33.3 & 29.9 \\
\hline & Total & 100 & 100 & 100 & 100 & 100 & 100 & 100 & 100 & 100 & 100 \\
\hline \multicolumn{12}{|c|}{ Non-Targeted Counties } \\
\hline & $\mathrm{N}=$ & 47 & 56 & 64 & 154 & 219 & 148 & 173 & 191 & 96 & 86 \\
\hline More Often & & 6.4 & 7.1 & 12.5 & 9.1 & 9.1 & 6.1 & 6.4 & 4.7 & 6.3 & 5.8 \\
\hline About the Same & & 68.1 & 53.6 & 50.0 & 57.8 & 60.3 & 44.6 & 48.6 & 71.7 & 68.8 & 52.3 \\
\hline Less Often & & 25.5 & 39.3 & 37.5 & 33.1 & 30.6 & 49.3 & 45.1 & 23.6 & 25.0 & 41.9 \\
\hline & Total & 100 & 100 & 100 & 100 & 100 & 100 & 100 & 100 & 100 & 100 \\
\hline
\end{tabular}

There was not a statistically significant change in the proportion of respondents in either the targeted or non-targeted counties reporting that they had driven within two hours of drinking alcoholic beverages in the past 30 days after any of the holiday enforcement crackdowns or overall from the first to the last survey administration. The 6.0-percentage-point increase after the July $4^{\text {th }} 2003$ crackdown in the targeted county was not statistically significant, nor were the 1.7- and 1.5-percentage-point decreases following the 2004 and 2005 Labor Day holiday crackdowns. Slight increases occurred in non-targeted counties after each holiday crackdown, but none of these were statistically significant. The results are presented in Table 11.

Table 11. West Virginia DMV Office Survey Q7: Reported Having Driven One or More Times in the Past 30 Days Within Two Hours of Drinking an Alcoholic Beverage for Targeted and Non-Targeted Counties

\begin{tabular}{|c|c|c|c|c|c|c|c|c|c|c|c|}
\hline Targeted Counties & & $\begin{array}{c}\text { Jun } \\
2003 \\
\text { Pre } \\
(\%)\end{array}$ & $\begin{array}{c}\text { Jun } \\
2003 \\
\text { Mid } \\
(\%)\end{array}$ & $\begin{array}{c}\text { July } \\
2003 \\
\text { Post } \\
\text { (\%) }\end{array}$ & $\begin{array}{c}\text { May } \\
2004 \\
(\%)\end{array}$ & $\begin{array}{c}\text { Jun } \\
2004 \\
(\%)\end{array}$ & $\begin{array}{c}\text { Aug } \\
2004 \\
\text { Pre } \\
(\%)\end{array}$ & $\begin{array}{c}\text { Sept } \\
2004 \\
\text { Post } \\
(\%)\end{array}$ & $\begin{array}{c}\text { Apr } \\
2005 \\
(\%)\end{array}$ & $\begin{array}{c}\text { Aug } \\
2005 \\
\text { Pre } \\
(\%)\end{array}$ & $\begin{array}{c}\text { Sep } \\
2005 \\
\text { Post } \\
(\%)\end{array}$ \\
\hline & $\mathrm{N}=$ & 183 & 222 & 145 & 967 & 977 & 693 & 641 & 861 & 871 & 879 \\
\hline Yes & & 7.1 & 6.8 & 13.1 & 10.4 & 10.8 & 13.7 & 12.0 & 12.5 & 10.4 & 8.9 \\
\hline \multirow[t]{2}{*}{ No } & & 92.9 & 93.2 & 86.9 & 89.6 & 89.2 & 86.3 & 88.0 & 87.5 & 89.6 & 91.1 \\
\hline & Total & 100 & 100 & 100 & 100 & 100 & 100 & 100 & 100 & 100 & 100 \\
\hline \multicolumn{12}{|c|}{ Non-Targeted Counties } \\
\hline & $\mathrm{N}=$ & 442 & 586 & 525 & 863 & 948 & 939 & 894 & 923 & 963 & 969 \\
\hline Yes & & 5.2 & 6.1 & 6.1 & 13.2 & 11.2 & 10.4 & 10.9 & 7.2 & 5.5 & 6.3 \\
\hline No & & 94.8 & 93.9 & 93.9 & 86.8 & 88.8 & 89.6 & 89.1 & 92.8 & 94.5 & 93.7 \\
\hline & Total & 100 & 100 & 100 & 100 & 100 & 100 & 100 & 100 & 100 & 100 \\
\hline
\end{tabular}




\section{E. Exposure to Enforcement}

There was a significant 12-percentage-point increase from 7.3 to 19.3 percent in the proportion of drivers reporting that they had gone through a sobriety checkpoint in targeted counties from the first to the last DMV survey administration $\left(\chi^{2}(1)=16.180, \underline{p<.001)}\right.$. There was not a similar increase in reports of going through sobriety checkpoints in the past 30 days for non-targeted county respondents $\left(\chi^{2}(1)=0.558, \underline{p}=.445\right)$. There were significant increases in those reporting having gone through a sobriety checkpoint in targeted counties after the July $4^{\text {th }} 2003$ holiday crackdown $\left(\chi^{2}(1)=14.817, \underline{p<.001)}\right.$ and after the 2005 Labor Day holiday crackdown $\left(\chi^{2}(1)=\right.$ $5.863, \mathrm{p}=.015)$, but not the 2004 Labor Day holiday crackdown after which there was a 2.9-percentage-point decrease in those reporting having gone through a sobriety checkpoint in the past 30 days $\left(\chi^{2}(1)=2.004, p=.157\right)$. Results are presented in Table 12.

Table 12. West Virginia DMV Office Survey Q12: Reported Having Gone Through a Sobriety Checkpoint in Past 30 Days for Targeted and Non-Targeted Counties

\begin{tabular}{|c|c|c|c|c|c|c|c|c|c|c|c|}
\hline Targeted Counties & & $\begin{array}{c}\text { Jun } \\
2003 \\
\text { Pre } \\
\text { (\%) }\end{array}$ & $\begin{array}{c}\text { Jun } \\
2003 \\
\text { Mid } \\
(\%)\end{array}$ & $\begin{array}{l}\text { July } \\
2003 \\
\text { Post } \\
(\%)\end{array}$ & $\begin{array}{l}\text { May } \\
2004 \\
(\%)\end{array}$ & $\begin{array}{c}\text { Jun } \\
2004 \\
(\%)\end{array}$ & $\begin{array}{c}\text { Aug } \\
2004 \\
\text { Pre } \\
(\%)\end{array}$ & $\begin{array}{l}\text { Sept } \\
2004 \\
\text { Post } \\
(\%)\end{array}$ & $\begin{array}{c}\text { Apr } \\
2005 \\
(\%)\end{array}$ & $\begin{array}{c}\text { Aug } \\
2005 \\
\text { Pre } \\
\text { (\%) }\end{array}$ & $\begin{array}{c}\text { Sep } \\
2005 \\
\text { Post } \\
(\%)\end{array}$ \\
\hline & $\mathrm{N}=$ & 193 & 221 & 148 & 982 & 984 & 719 & 667 & 915 & 901 & 897 \\
\hline Yes & & 7.3 & 6.8 & 21.6 & 13.1 & 15.5 & 18.8 & 15.9 & 14.6 & 15.0 & 19.3 \\
\hline \multirow[t]{2}{*}{ No } & & 92.7 & 93.2 & 78.4 & 86.9 & 84.5 & 81.2 & 84.1 & 85.4 & 85.0 & 80.7 \\
\hline & Total & 100 & 100 & 100 & 100 & 100 & 100 & 100 & 100 & 100 & 100 \\
\hline \multicolumn{12}{|c|}{ Non-Targeted Counties } \\
\hline & $\mathrm{N}=$ & 448 & 597 & 520 & 886 & 976 & 962 & 918 & 946 & 995 & 990 \\
\hline Yes & & 13.8 & 9.7 & 12.3 & 12.0 & 15.5 & 11.0 & 11.9 & 10.0 & 12.1 & 15.4 \\
\hline \multirow[t]{2}{*}{ No } & & 86.2 & 90.3 & 87.7 & 88.0 & 84.5 & 89.0 & 88.1 & 90.0 & 87.9 & 84.6 \\
\hline & Total & 100 & 100 & 100 & 100 & 100 & 100 & 100 & 100 & 100 & 100 \\
\hline
\end{tabular}

\section{West Virginia Roadside Survey}

\section{F. Direct Observations of Driver BACs}

BACs were measured from drivers agreeing to take a "blind," anonymous breath test. As presented in Table 13, there was an overall 2.8-percentage-point, statistically significant decrease in the percentage of positive BACs from April, May, and June 2004 to the same three months in $2005\left(\chi^{2}(1)=5.706, \underline{p} .=017\right)$. 
Figure 2. West Virginia Roadside Survey: Driver BACs (2004 versus 2005)

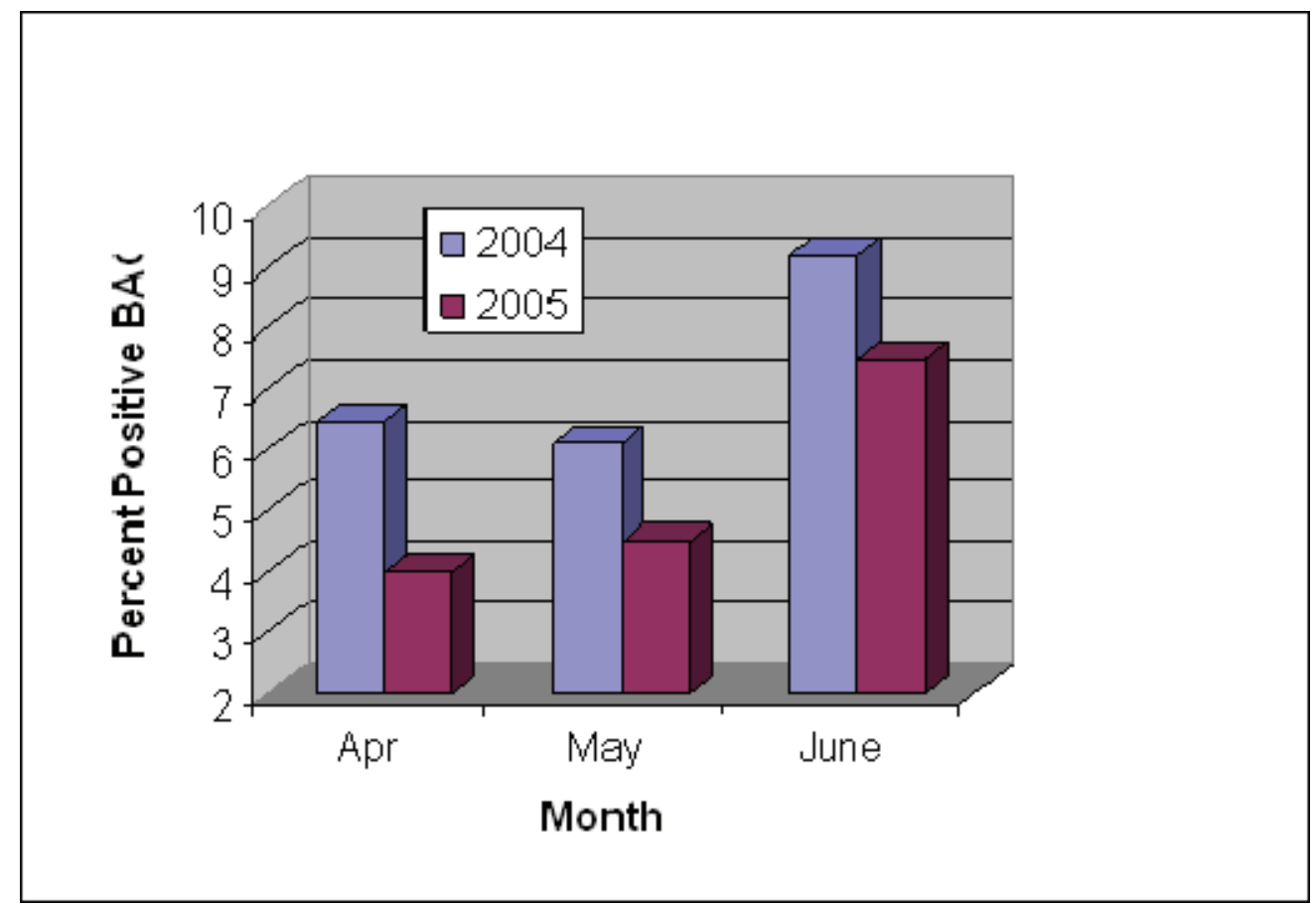

As indicated in Table 14, the breath test refusal rates decreased non-significantly by 1.4 percentage points from 3.7 percent for April, May, and June of 2005 to 2.4 percent for the same three months in $2005\left(\chi^{2}(1)=2.828\right.$, $p \geq 093$ ). Thus, refusal rates did not change significantly for either of these periods. It is important to note when viewing these tables that drinking and driving follows seasonal patterns irrespective of program activities.

Drinking and driving are higher during summer months and lower during spring and fall.

Table 13. West Virginia Roadside Survey: Driver BACs and Refusals

\begin{tabular}{|c|c|c|c|c|c|c|c|c|c|c|c|c|}
\hline Driver BACs & & $\begin{array}{c}\text { Apr } \\
2004 \\
\text { (\%) }\end{array}$ & $\begin{array}{c}\text { May } \\
2004 \\
\text { (\%) }\end{array}$ & $\begin{array}{c}\text { Jun } \\
\text { 2004 } \\
\text { (\%) }\end{array}$ & $\begin{array}{c}\text { Jul } \\
\mathbf{2 0 0 4} \\
(\%)\end{array}$ & $\begin{array}{c}\text { Aug } \\
2004 \\
(\%)\end{array}$ & $\begin{array}{c}\text { Sept } \\
2004 \\
(\%)\end{array}$ & $\begin{array}{c}\text { Oct } \\
2004 \\
(\%)\end{array}$ & $\begin{array}{c}\text { Nov } \\
2004 \\
(\%)\end{array}$ & $\begin{array}{c}\text { Apr } \\
2005 \\
(\%)\end{array}$ & $\begin{array}{c}\text { May } \\
2005 \\
(\%)\end{array}$ & $\begin{array}{c}\text { Jun } \\
2005 \\
\text { (\%) }\end{array}$ \\
\hline & $\mathrm{N}=$ & 278 & 396 & 368 & 378 & 446 & 253 & 888 & 273 & 375 & 508 & 134 \\
\hline Positive BAC & & 6.5 & 6.1 & 9.2 & 6.1 & 3.8 & 5.5 & 4.8 & 5.5 & 4.0 & 4.5 & 7.5 \\
\hline Zero BAC & & 91.7 & 90.4 & 85.9 & 88.1 & 90.6 & 89.7 & 92.0 & 90.5 & 94.7 & 92.7 & 88.8 \\
\hline Refused Test & & 1.8 & 3.5 & 4.9 & 5.8 & 5.6 & 4.7 & 3.2 & 4.0 & 1.3 & 2.8 & 3.7 \\
\hline & Total & 100 & 100 & 100 & 100 & 100 & 100 & 100 & 100 & 100 & 100 & 100 \\
\hline
\end{tabular}


Table 14. West Virginia Roadside Survey: Breath Test Refusal Rates

\begin{tabular}{|c|c|c|c|c|c|c|c|c|c|c|c|}
\hline Refusal Rates & $\begin{array}{c}\text { Apr } \\
2004 \\
(\%)\end{array}$ & $\begin{array}{c}\text { May } \\
2004 \\
(\%)\end{array}$ & $\begin{array}{c}\text { Jun } \\
2004 \\
\text { (\%) }\end{array}$ & $\begin{array}{c}\text { Jul } \\
2004 \\
(\%)\end{array}$ & $\begin{array}{c}\text { Aug } \\
2004 \\
(\%)\end{array}$ & $\begin{array}{c}\text { Sept } \\
2004 \\
(\%)\end{array}$ & $\begin{array}{c}\text { Oct } \\
2004 \\
(\%)\end{array}$ & $\begin{array}{c}\text { Nov } \\
2004 \\
(\%)\end{array}$ & $\begin{array}{c}\text { Apr } \\
2005 \\
(\%)\end{array}$ & $\begin{array}{c}\text { May } \\
2005 \\
\text { (\%) }\end{array}$ & $\begin{array}{c}\text { Jun } \\
2005 \\
\text { (\%) }\end{array}$ \\
\hline $\mathrm{N}=$ & 278 & 396 & 368 & 378 & 446 & 253 & 888 & 273 & 375 & 508 & 134 \\
\hline Refused BAC Test & 1.8 & 3.5 & 4.9 & 5.8 & 5.6 & 4.7 & 3.2 & 4.0 & 1.3 & 2.8 & 3.7 \\
\hline Took BAC Test* & 98.2 & 96.5 & 95.1 & 94.2 & 94.4 & 95.3 & 96.8 & 96.0 & 98.7 & 97.2 & 96.3 \\
\hline Total & 100 & 100 & 100 & 100 & 100 & 100 & 100 & 100 & 100 & 100 & 100 \\
\hline
\end{tabular}

*Includes all positive BACs and all zero BACs combined.

\section{G. Driver BACs by Time of Night, Age, and Gender}

The proportion of drivers with a positive BAC increased steadily throughout the night from a low of 1.1 percent with any positive BAC between 9 p.m. and 10 p.m. to a high of 8.2 percent from 1 a.m. to 2 a.m. The highest proportions of those with BACs of .08 or higher occurred from 1 a.m. to 2 a.m. Sobriety checkpoints generally began between 8:30 p.m. and 9 p.m. and data collection generally began shortly afterwards. The proportion of positive BACs at higher levels increased steadily throughout the night. Most of the drivers with a positive BAC had a BAC less than .05 across all times of night. In total, only .6 percent of the 4,182 drivers who provided a BAC (in cases of arrest, the police provided the preliminary or evidentiary BAC test result) were at or above the legal limit. The results are reported in Table 15.

Table 15. West Virginia Roadside Survey: Distribution of Roadside BACs by Category and Hour of Night

\begin{tabular}{rrrrrr}
\hline Hour of Night & Zero BAC & $\mathbf{. 0 0 1 - . 0 4 9}$ & $\mathbf{. 0 5}-.079$ & \multicolumn{1}{c}{.08+ } & \multicolumn{1}{c}{ Totals } \\
\hline & $(\mathrm{N}=3946)$ & $(\mathrm{N}=186)$ & $(\mathrm{N}=)$ & $(\mathrm{N}=)$ & $(\mathrm{N}=4182)$ \\
9 p.m.-10 p.m. & $98.9 \%$ & $1.1 \%$ & $0.0 \%$ & $0.0 \%$ & $(\mathrm{~N}=90)$ \\
10 p.m.-11 p.m. & $96.2 \%$ & $3.4 \%$ & $0.2 \%$ & $0.2 \%$ & $(\mathrm{~N}=910)$ \\
11 p.m.-12 a.m. & $94.6 \%$ & $4.2 \%$ & $0.6 \%$ & $0.6 \%$ & $(\mathrm{~N}=1894)$ \\
12 a.m.- 1 a.m. & $92.7 \%$ & $5.5 \%$ & $1.0 \%$ & $0.8 \%$ & $(\mathrm{~N}=922)$ \\
1 a.m.- 2 a.m. & $91.8 \%$ & $6.3 \%$ & $0.8 \%$ & $1.1 \%$ & $(\mathrm{~N}=366)$ \\
\hline
\end{tabular}

Table 16 contains the results for positive BACs by age group across each month of roadside surveys. Generally, the proportion of positive BACs were highest for the 25- to 34-year-old group $(\mathrm{M}=7.6 \%)$ and for the 50- to 64-year-old group across all sobriety checkpoints $(\mathrm{M}=7.5 \%)$. The 65 -year-olds and older group had the lowest proportion of positive BACs with an average of 3.8 percent. The 16- to 24-year-old group was the second lowest with an average of 5.3 percent positive BACs across all sobriety checkpoint roadside surveys. More drivers age 35 to 49 came through the sobriety checkpoints than any other group. A total of 1,395 drivers from this age group were sampled. The next closest group were the 16- to 24 -year-olds $(\mathrm{N}=1034)$, followed very closely by the 25- to 34-year-olds $(\mathrm{N}=1032)$. There were only 164 drivers in the 65 and older age group throughout the study. 
As indicated in Table 17, the proportion of drivers going through the sobriety checkpoints from younger age groups increased slightly during later hours. The proportion of drivers at sobriety checkpoints from the youngest group, drivers 16- to 24 years old, increased until 12 a.m., to a high of 25.9 percent, and then steadily decreased into the later hours of the night to a low of 16.8 percent between 1 and 2 a.m.. The proportion of drivers from the 25- to 34-year-old age group remained relatively stable throughout the night until after 1 a.m., when fewer drivers in this age group were out on the roads compared to earlier hours. The proportion of drivers from the 35- to 49-year-old age group decreased from a high of 36.2 percent from 9 to 10 p.m. until 12 a.m., when the proportion of drivers in this age group increased again until they comprised the largest group of drivers on the road between 1 and 2 a.m. During later hours, the traffic volume was much lower and the drivers on the roads were generally from the 35 to 49 and 50 to 64 age groups.

Table 16. West Virginia Roadside Survey: Distribution of BACs by Age Group

\begin{tabular}{|c|c|c|c|c|c|c|c|c|c|c|c|}
\hline Refusal Rates & $\begin{array}{c}\text { Apr } \\
2004 \\
(\%)\end{array}$ & $\begin{array}{c}\text { May } \\
2004 \\
(\%)\end{array}$ & $\begin{array}{c}\text { Jun } \\
2003 \\
(\%)\end{array}$ & $\begin{array}{c}\text { Jul } \\
2004 \\
(\%)\end{array}$ & $\begin{array}{c}\text { Aug } \\
2004 \\
(\%)\end{array}$ & $\begin{array}{l}\text { Sept } \\
2004 \\
(\%)\end{array}$ & $\begin{array}{c}\text { Oct } \\
2004 \\
(\%)\end{array}$ & $\begin{array}{c}\text { Nov } \\
2004 \\
(\%)\end{array}$ & $\begin{array}{c}\text { Apr } \\
2005 \\
(\%)\end{array}$ & $\begin{array}{c}\text { May } \\
2005 \\
(\%)\end{array}$ & $\begin{array}{c}\text { Jun } \\
2005 \\
(\%)\end{array}$ \\
\hline $16-24$ & 63 & 103 & 77 & 68 & 86 & 72 & 196 & 42 & 96 & 137 & 36 \\
\hline Positive BAC & 4.8 & 2.9 & 6.5 & 4.4 & 1.2 & 5.6 & 6.1 & 4.8 & 4.4 & 1.7 & 16.0 \\
\hline $25-34$ & 77 & 90 & 91 & 74 & 104 & 56 & 201 & 74 & 68 & 118 & 25 \\
\hline Positive BAC & 6.5 & 5.6 & 13.2 & 9.5 & 3.8 & 7.1 & 7.0 & 9.5 & 4.4 & 1.7 & 16.0 \\
\hline $35-49$ & 76 & 102 & 102 & 124 & 134 & 69 & 289 & 92 & 118 & 162 & 40 \\
\hline Positive BAC & 5.3 & 7.8 & 10.8 & 4.0 & 5.2 & 4.3 & 3.5 & 3.3 & 5.1 & 6.8 & 5.0 \\
\hline $50-64$ & 43 & 65 & 61 & 55 & 76 & 37 & 157 & 36 & 70 & 60 & 21 \\
\hline Positive BAC & 14.0 & 12.3 & 8.2 & 7.3 & 6.6 & 5.4 & 4.5 & 5.6 & 5.7 & 8.3 & 4.8 \\
\hline $65+$ & 7 & 11 & 19 & 26 & 15 & 7 & 16 & 16 & 18 & 16 & 7 \\
\hline Positive BAC & 0.0 & 0.0 & 5.3 & 15.4 & 0.0 & 14.3 & 0.0 & 6.3 & 0.0 & 0.0 & 0.0 \\
\hline
\end{tabular}

Table 17. West Virginia Roadside Survey: Proportion of Drivers at Sobriety Checkpoints by Age Group and Hour of Night

\begin{tabular}{|c|c|c|c|c|c|c|}
\hline & $\begin{array}{l}9 \text { p.m.-10 } \\
\text { p.m. }\end{array}$ & $\begin{array}{l}10 \text { p.m.-11 } \\
\text { p.m. }\end{array}$ & $\begin{array}{l}11 \text { p.m.-12 } \\
\text { a.m. }\end{array}$ & $\begin{array}{c}12 \text { a.m.-1 } \\
\text { a.m. }\end{array}$ & $\begin{array}{c}1 \text { a.m.-2 } \\
\text { a.m. }\end{array}$ & Totals \\
\hline Age Group & $(\mathrm{N}=94)$ & $(\mathrm{N}=949)$ & $(\mathrm{N}=1968)$ & $(\mathrm{N}=960)$ & $(\mathrm{N}=380)$ & $(\mathrm{N}=4351)$ \\
\hline $16-24$ & $20.2 \%$ & $24.8 \%$ & $25.9 \%$ & $21.6 \%$ & $16.8 \%$ & $(\mathrm{~N}=1034)$ \\
\hline $25-34$ & $23.4 \%$ & $22.2 \%$ & $25.3 \%$ & $24.2 \%$ & $18.2 \%$ & $(\mathrm{~N}=1032)$ \\
\hline $35-49$ & $36.2 \%$ & $33.4 \%$ & $30.3 \%$ & $32.6 \%$ & $35.5 \%$ & $(\mathrm{~N}=1395)$ \\
\hline $50-64$ & $16.0 \%$ & $16.5 \%$ & $15.2 \%$ & $17.9 \%$ & $21.6 \%$ & $(\mathrm{~N}=726)$ \\
\hline $65+$ & $4.3 \%$ & $3.1 \%$ & $3.3 \%$ & $3.8 \%$ & $7.9 \%$ & $(\mathrm{~N}=164)$ \\
\hline Total & $100 \%$ & $100 \%$ & $100 \%$ & $100 \%$ & $100 \%$ & \\
\hline
\end{tabular}


As indicated in Table 18, the proportion of male drivers with positive BACs at sobriety checkpoints decreased significantly by 3.2 percentage points from 8.3 percent for April, May, and June combined for 2004 compared to 5.1 percent for the same three months combined for $2005\left(\chi^{2}(1)=4.347, p=.037\right)$. Female drivers had a smaller, non-significant decrease of 2.4 percentage points from 6.5 percent for April through June of 2004 to 4.1 percent for the same three months of $2005\left(\chi^{2}(1)=1.918, \underline{p}=.166\right)$. There were generally more male drivers going through the sobriety checkpoint locations during all survey periods and they generally were more likely to have positive BACs, but the proportion of men drinking and driving decreased more than the women, and came much closer to the to the same rate of positive BACs as the women.

Table 18. West Virginia Roadside Survey: Distribution of BACs by Gender

\begin{tabular}{|c|c|c|c|c|c|c|c|c|c|c|c|}
\hline Refusal Rates & $\begin{array}{c}\text { Apr } \\
2004 \\
(\%)\end{array}$ & $\begin{array}{c}\text { May } \\
2004 \\
(\%)\end{array}$ & $\begin{array}{c}\text { Jun } \\
2003 \\
(\%)\end{array}$ & $\begin{array}{c}\text { Jul } \\
2004 \\
(\%)\end{array}$ & $\begin{array}{l}\text { Aug } \\
2004 \\
(\%)\end{array}$ & $\begin{array}{l}\text { Sept } \\
2004 \\
(\%)\end{array}$ & $\begin{array}{c}\text { Oct } \\
2004 \\
(\%)\end{array}$ & $\begin{array}{l}\text { Nov } \\
2004 \\
(\%)\end{array}$ & $\begin{array}{c}\text { Apr } \\
2005 \\
(\%)\end{array}$ & $\begin{array}{l}\text { May } \\
2005 \\
(\%)\end{array}$ & $\begin{array}{c}\text { Jun } \\
2005 \\
(\%)\end{array}$ \\
\hline Men & 148 & 245 & 207 & 206 & 248 & 141 & 515 & 157 & 216 & 310 & 78 \\
\hline Percent Positive BACs & 8.1 & 6.5 & 10.6 & 8.3 & 6.0 & 7.1 & 6.2 & 5.7 & 3.2 & 6.1 & 6.4 \\
\hline Women & 116 & 126 & 143 & 143 & 170 & 100 & 345 & 104 & 154 & 182 & 51 \\
\hline Percent Positive BACs & 5.2 & 6.3 & 8.4 & 4.2 & 1.2 & 4.0 & 3.2 & 5.8 & 5.2 & 1.6 & 9.8 \\
\hline
\end{tabular}

\section{West Virginia Alcohol-Related Fatality Analysis Using FARS 2000-2004}

\section{H. ARIMA Analyses of West Virginia Alcohol-Related Fatalities}

Time series analyses were used to show changes in West Virginia's alcohol-related fatal crash rates coincidental to the onset of the impaired driving crackdowns in targeted counties. Through an interrupted time series design, the ARIMA can determine if there is a change in number of alcohol-related fatal crashes beginning with the impaired driving crackdowns in July 2003. Within time series oftentimes, there is random noise that makes it difficult to determine any changes to the series. ARIMA modeling helps control for this by requiring the selection of a model that controls for periodic fluctuations in the data series. That is, a combination of parameters is entered into the analysis such that systematic fluctuations in the data (i.e., monthly "lags") are reduced to nonsignificance. Lags are numbered based on how many months it takes for a pattern to repeat. That is, a 12-month lag would indicate that there is some systematic change in the series that repeats annually. Lags are judged to be nonsignificant (or stationary) based on exploration of autocorrelations (AC) and partial autocorrelations (PAC) where the monthly lags are deemed to be random with 95 percent confidence. Lags may also be deemed "stationary" based on the Box-Ljung Statistic. Specifically, most lags are considered stationary if they are not significant on either the autocorrelations (AC and PAC) or the Box-Ljung. Lags at 1 and 12 months are held to a higher standard as they are "expected" lags. For these lags to be considered stationary there must be no significance for both measures. The parameters used to control the lags must significantly affect the series in order to be 
considered valid for inclusion in the model (e.g. see Table 19). We conducted the analyses using the "Trends" module of the software package SPSS 11.5.

The ARIMA model in this study describes patterns of crashes that were extracted from FARS data and applied parameters to model periodic fluctuations in crash rates. For instance, when West Virginia began its alcohol crackdowns in targeted counties, we expect alcohol-related fatal crash rates to decrease. As mentioned earlier, there is the possibility of nonperiodic fluctuations that might occur due to random noise or simply different numbers of weekend days in a given month. The modeling process accounts for these periodic variations in the series by including the appropriate parameter. The simplest models that created a stable or "stationary" series were used. Data results are reported with two groupings of three digits (e.g., (100) (001)). In each grouping of digits the first digit represents the "autoregressive" (AR) parameter; the second digit describes the "differencing" parameter; and the third digit is the "moving average" (MA) parameter. The first grouping is monthly parameters and the second grouping is seasonal parameters. Thus in the example above (100) (001) there is a single monthly autoregressive parameter, no differencing and a seasonal moving average. A statistically significant effect of the intervention (i.e., the alcohol mobilization) signifies that there was a change in the series coinciding with the intervention.

The data used for this analysis was from FARS. The data was analyzed using the time series analyses on monthly imputed alcohol-related fatality data. Some analyses included only the targeted counties while one analysis included all fatalities in the State as well as those from contiguous counties (as a covariate). The use of a covariate allowed the analysis to better control for cohort effects, economic changes and other external variables that may account for a change in crash rates at the time of the intervention. Adding the covariate to the ARIMA analyses account for any changes in monthly crash involvements in the targeted counties that also occur in the comparison counties. If there is a general upward trend in the comparison counties, it will make a downward trend in the target counties appear that much more apparent. Conversely, if a downward trend exists in the comparison counties starting at an intervention time for the target counties then for a similar downward change in the target counties to be statistically significant it will have to be a change of a greater magnitude than that of the comparison counties.

Table 19 displays the parameters used to create a stable series and demonstrate whether the estimated coefficient for the intervention (in this case a law change) was statistically significant or not as well as their significance levels. The tables also display whether the law change was significant or not. The "estimates" for intervention represents the average change in involvements per month (i.e., the size of the effect).

\section{Alcohol Related Fatalities Targeted Counties}

Since the beginning of West Virginia's Impaired Driving Crackdowns, there was a significant decrease in the alcohol-related fatality trend for targeted counties for an 18-month period from July 2003 through December 2004 compared to the trend for an 18-month period from January 2000 through June $2003(\mathrm{p}=.012)$. As Table 19 
indicates, the estimated reduction in the number of alcohol-related fatalities was .99 lives each month for the 18 months following the beginning of the campaign in the targeted counties. This represents a 24 percent reduction in fatalities from the 18-month period preceding the crackdown.

\section{$\underline{\text { Alcohol Related Fatalities Targeted Counties Men } 21 \text { to } 34}$}

Analyses of the alcohol-related fatalities for men 21 to 34 years old in targeted counties yielded a predicted reduction of .09 lives per month, but the reduction did not approach statistical significance $(\mathrm{p}=.787)$. Thus, the statewide alcohol-related fatality trend and the trend for men 21 to 34 years old were both in the right direction, but neither reduction approached statistical significance.

Table 19. West Virginia Targeted County Alcohol-Related Fatality Trend ARIMA Results: Parameter Estimates for Alcohol-Related Fatalities

\begin{tabular}{llcccc}
\hline & & Estimates & Standard Error & $\mathrm{t}$ & Significance \\
\hline Regression Coefficients & AR1 & -.3043 & .1231 & -2.4728 & .016 \\
& SMA1 & .5859 & .1866 & 3.1397 & .002 \\
& Intervention & -.9851 & .3799 & -2.5930 & .012 \\
Constant & & 4.2346 & .1485 & 28.5169 & .000 \\
\hline
\end{tabular}


Figure 3 shows the reduction in alcohol-related fatalities in targeted counties as a result of the campaign.

Figure 3. West Virginia Alcohol-Related Fatalities for Targeted Counties 2000-2004

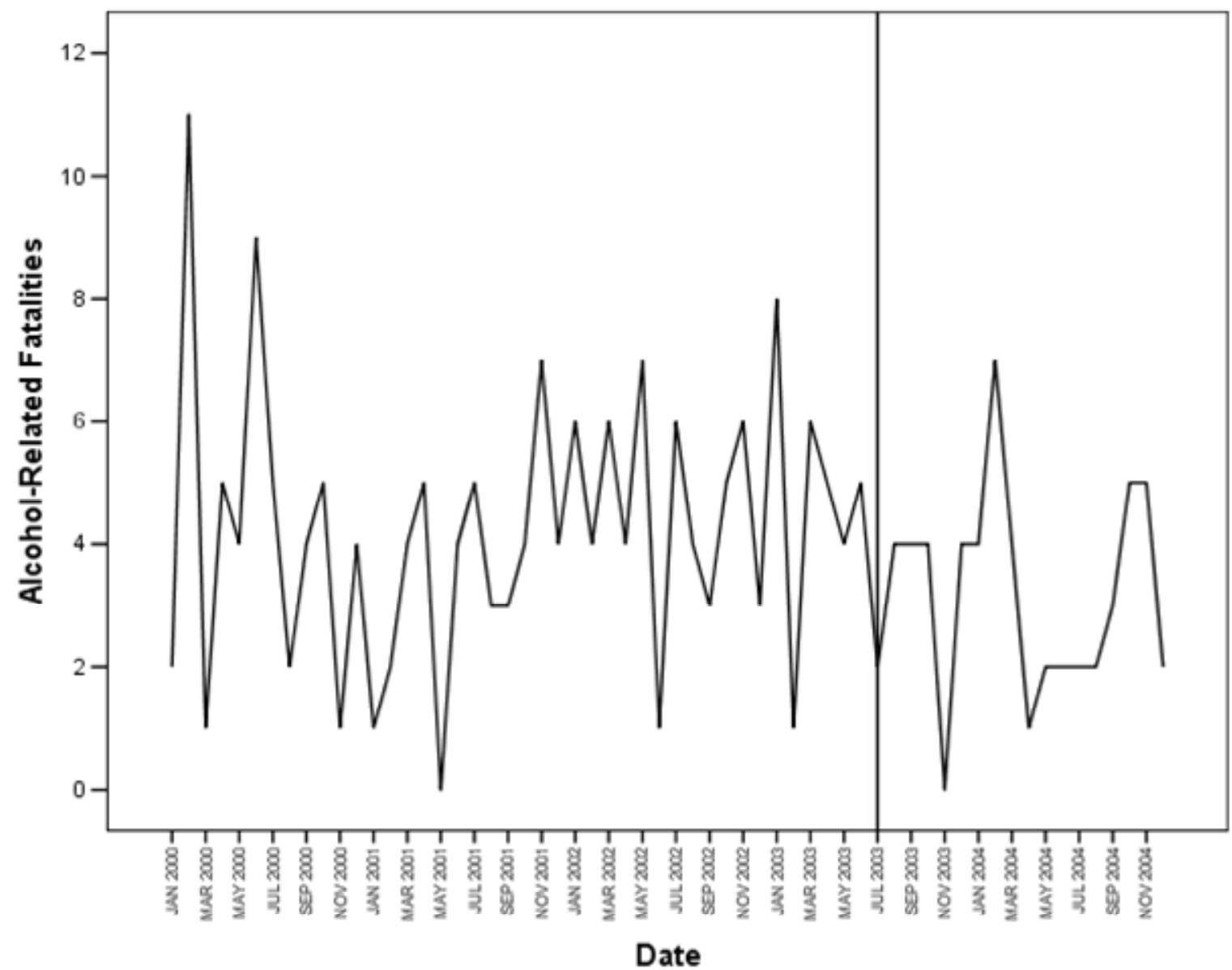

West Virginia Alcohol Related Fatalities With Contiguous County Covariate

ARIMA analysis of the West Virginia's statewide alcohol-related fatality trend used the alcohol-related fatality totals for each month from contiguous counties as a covariate to help account for noise and the effects of drinking and driving trends in bordering counties. The random effects model (000) (000) was used for the ARIMA because the inclusion of the alcohol-related fatalities from contiguous counties as a covariate left no significant autocorrelations and no significant partial autocorrelations. This model resulted in the estimation of a reduction of about 1.6 fatalities each month, but this estimated reduction did not approach statistical significant $(\mathrm{p}=.198)$.

Thus, although there was a significant effect of the campaign on alcohol-related fatalities in the targeted counties, the reduction was not statewide. The results are presented in Table 20. 
Table 20. West Virginia Alcohol-Related Fatality Trend Statewide ARIMA Results Including a Covariate: Parameter Estimates for Alcohol-Related Fatalities Using Alcohol-Related Fatalities From Contiguous Counties as a Covariate

\begin{tabular}{llcccc}
\hline & & Estimates & Standard Error & $\mathrm{t}$ & Significance \\
\hline Regression & Intervention & -1.5681 & 1.2050 & -1.3013 & .198 \\
Coefficients & Contiguous & .3138 & .1468 & 2.1373 & .037 \\
& County Fatalities & 10.0513 & 1.7633 & 5.701 & .000 \\
\hline
\end{tabular}

\section{West Virginia Telephone Surveys}

\section{Public Awareness of Alcohol Crackdown}

From 2003 to 2005, immediately before and after each crackdown period, public awareness surveys were administered to a statewide sample of drivers who had consumed an alcoholic beverage within the last year. Respondents answered a series of questions about the visibility of any public information and enforcement efforts that may have taken place in the past 30 days (from the date of the survey). The questions were used to gauge any change in media awareness from before the crackdown to after the crackdown.

Figure 4. Visibility of Police on Roads: All Respondents and Respondents 18 to 34 Years Old

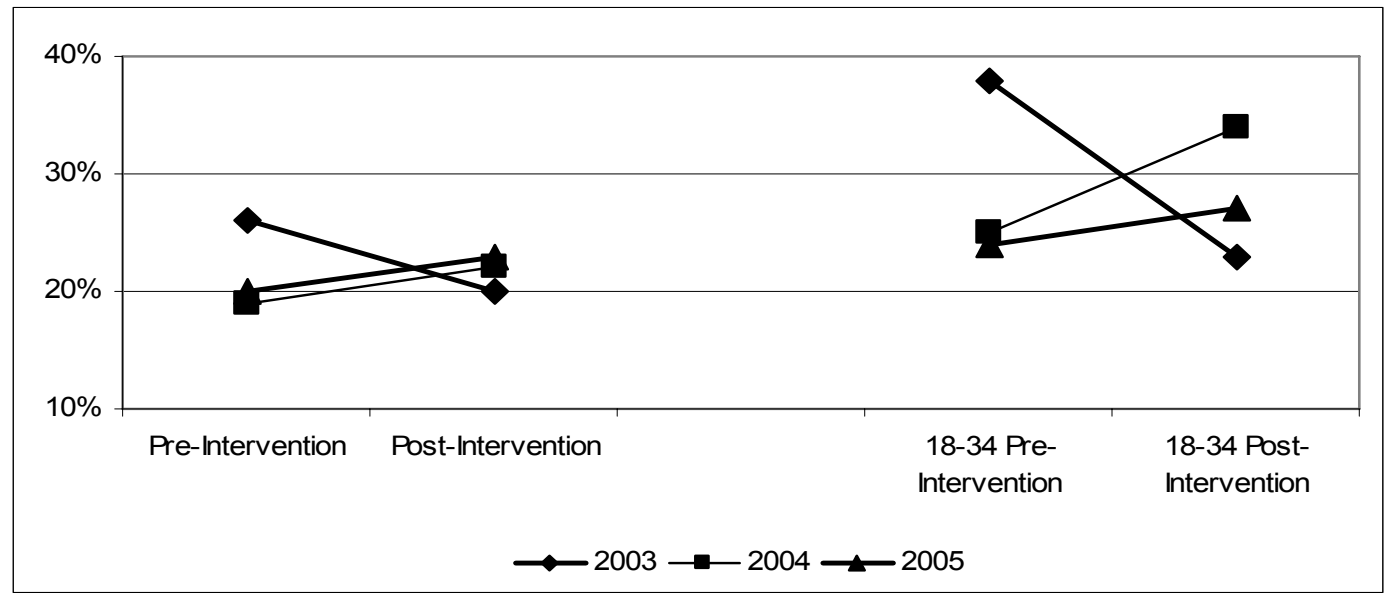

Visibility of Police on Roads: Aside from the first crackdown period, when visibility of police on the roads decreased, significantly more people reported seeing police on the roads following the alcohol crackdowns in 2004 and 2005. Overall, more of the targeted younger respondents reported an increased police presence on the road during the crackdown periods. As Figure 4 shows, the proportion of respondents who had seen police more often than usual increased from 19 to 22 percent during the 2004 crackdown, and from 20 to 23 percent during the 2005 
crackdown, and significantly decreased from 26 to 20 percent $(p<.01)$ during the 2003 crackdown. The pattern of change was similar among 18- to 34-year-old respondents.

Seen or Heard Messages Encouraging People Not to Drink and Drive: Overall, the majority of respondents, and specifically the younger targeted respondents, had seen or heard crackdown messages. As Figure 5 shows, the proportion of respondents who had seen or heard messages that encouraged people to avoid driving after drinking remained at 86 percent during the 2003 crackdown period, and increased from 83 to 85 percent during the 2004 crackdown, and significantly increased from 78 to 84 percent during the 2005 crackdown $(\mathrm{p}<.05)$. Among the targeted 18- to 34-year-old respondents, the number decreased from 91 to 88 percent during the 2003 crackdown, increased significantly from 81 to 90 percent during the 2004 crackdown $(\mathrm{p}<.05)$, and increased from 78 to 83 percent during the 2005 crackdown. Although the baseline measure of awareness appears to decreases after each year of the crackdown, it is important to recall that the telephone survey samples came from areas that included both high and low levels of media and enforcement activities during the crackdown.

\section{Figure 5. Seen or Heard Messages Encouraging People Not to Drink: All Respondents} and Respondents 18 to 34 Years Old

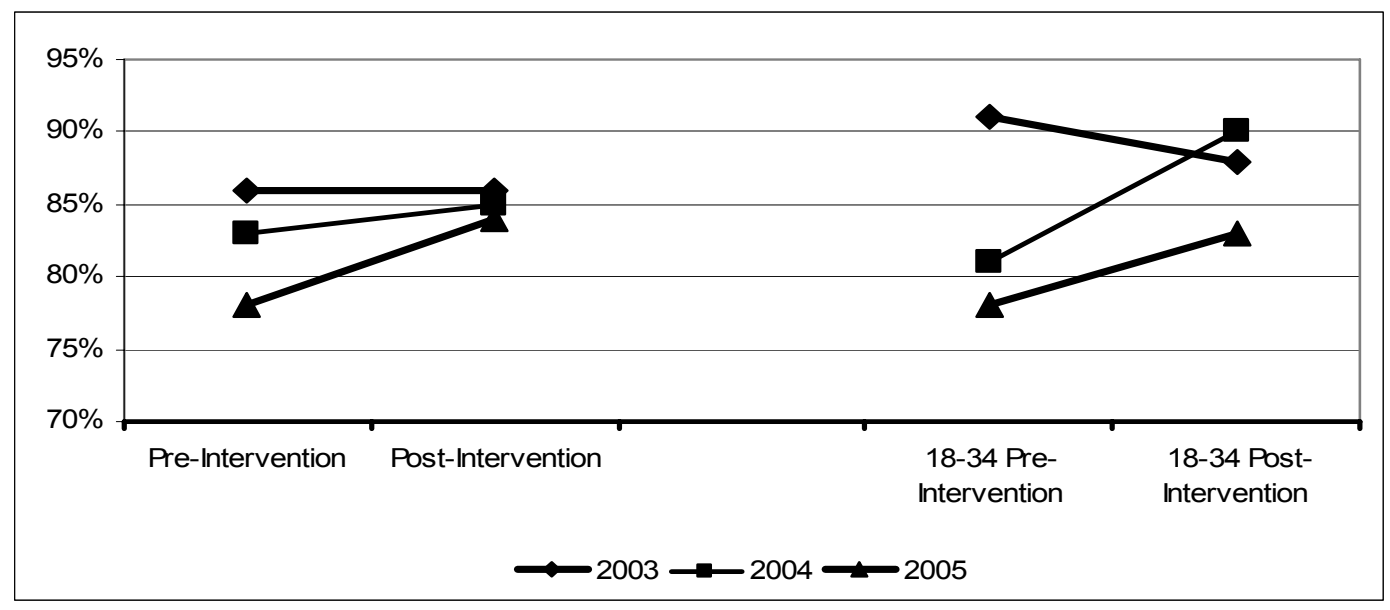

Increased Number of Messages Seen or Heard in Past 30 Days: The proportion of respondents who said they saw or heard more messages than usual on TV or the radio increased significantly in all three pre-and postcrackdown comparisons: From 25 to 35 percent in the 2003 crackdown $(p<.01)$, from 21 to 31 percent during the 2004 crackdown $(p<.01)$, and from 21 percent to 30 percent during the 2005 crackdown $(p<.01)$. As Figure 6 shows, the pattern of data was similar among 18- to 34-year-old respondents; their proportion increased significantly from 22 to 40 percent during the 2003 crackdown $(p<.01)$. However, during the 2004 and 2005 crackdowns, these increases were not significant. Although the overall pre-and post-measure of awareness decreases after each year of the crackdown, which appears to be contrary to the ratcheting effect of increasing yearly gains, it is important to recall that that the telephone survey samples were drawn from areas that included both high and low levels of media and enforcement activities during the crackdown. 
Figure 6. Increased Number of Messages Seen or Heard in Past 30 Days: All Respondents and Respondents 18 to 34 Years Old

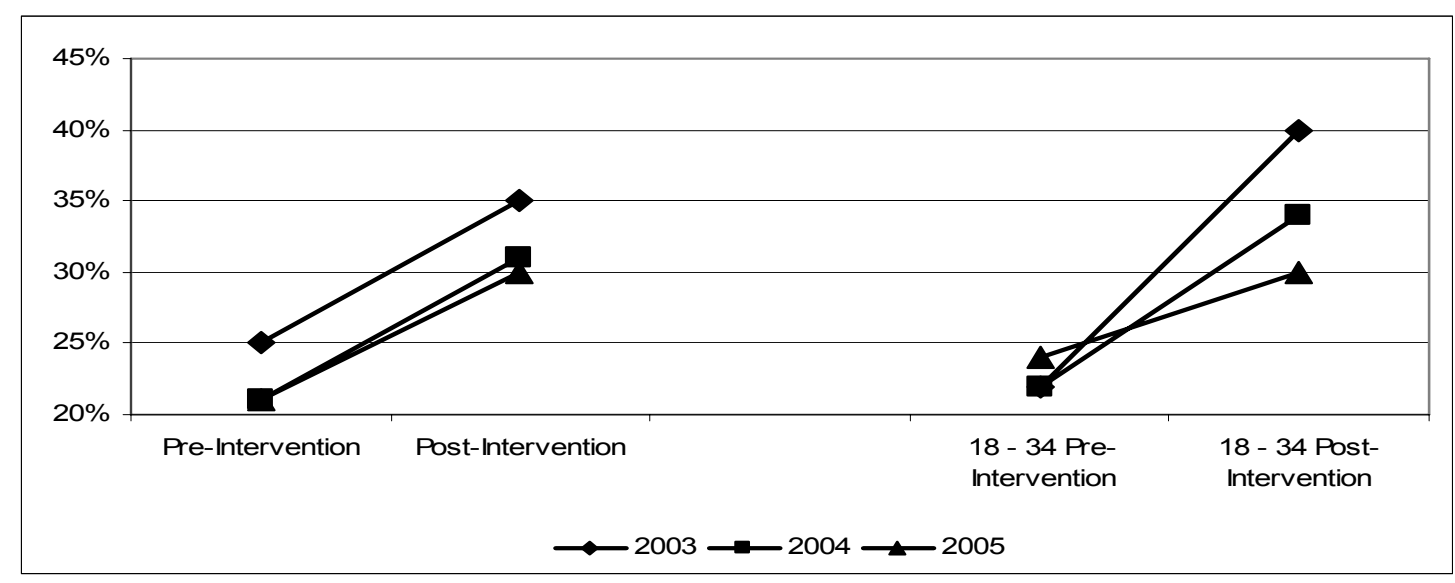

Special Efforts by Police: The proportion of respondents who saw or heard about special police efforts to reduce driving under the influence or driving drunk in their communities increased significantly in all three comparisons as Figure 7 shows, from 34 to 50 percent during the 2003 crackdown $(p<.01)$, from 38 to 46 percent during the 2004 crackdown $(p<.05)$, and from 37 to 44 percent during the 2005 crackdown $(p<.05)$. The pattern of data was similar among 18- to 34-year-old respondents; however, only the percent change from 25 to 46 percent during the 2003 crackdown was statistically significant. It is interesting to note that for all respondents and young respondents the greatest gains occurred during the first crackdown in 2003.

Figure 7. Seen or Heard Special Efforts by Police to Reduce Drunk Driving:

\section{All Respondents and Respondents 18 to 34 Years Old}

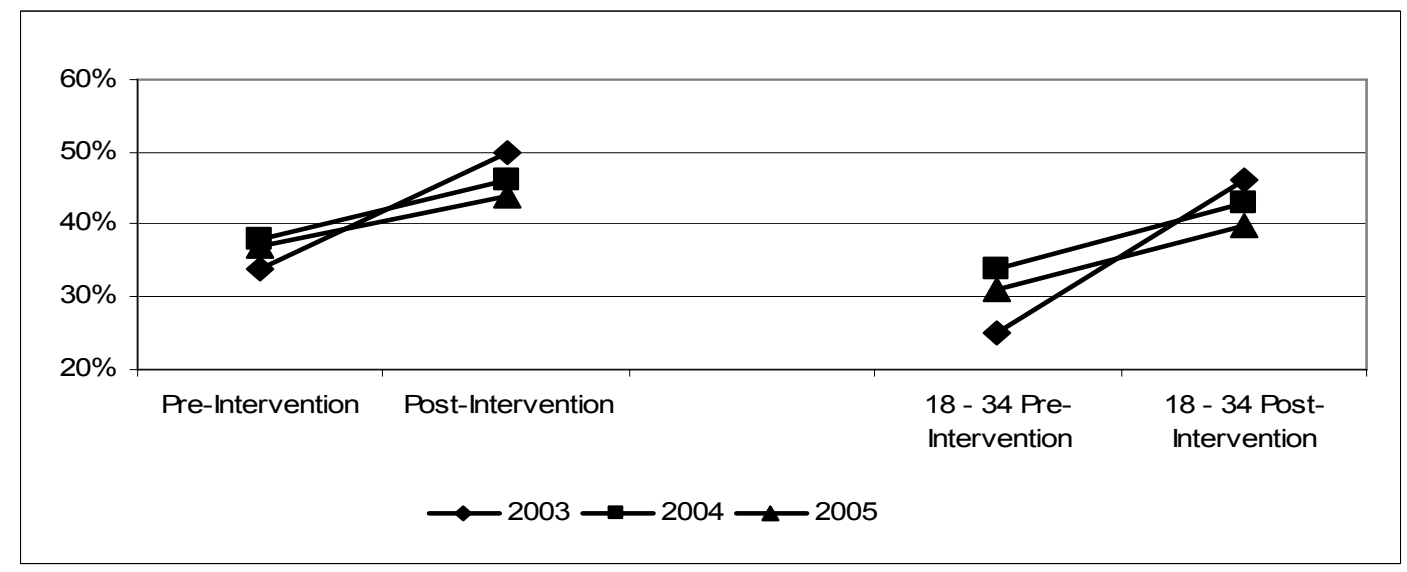

Police Checkpoints: Across all three crackdown periods, the proportion of respondents who saw or heard something about police setting up checkpoints or other enforcement efforts to catch impaired drivers increased: from 48 to 60 percent $(p<.05)$ in 2003; from 46 to 61 percent $(p<.01)$ in 2004, and then a slight increase from 54 to 56 percent in 2005 (Figure 8). The pattern of data was similar among 18- to 34-year-old respondents; however, 
only the percent change from 36 to 54 percent during the 2004 crackdown was statistically significant $(p<.01)$. Overall, there was a ratcheting effect with the baseline measure for awareness higher after each mobilization. In addition, younger respondents had an overall lower awareness compared to all respondents.

Figure 8. Awareness of Police Checkpoints: All Respondents and Respondents 18 to 34 Years Old

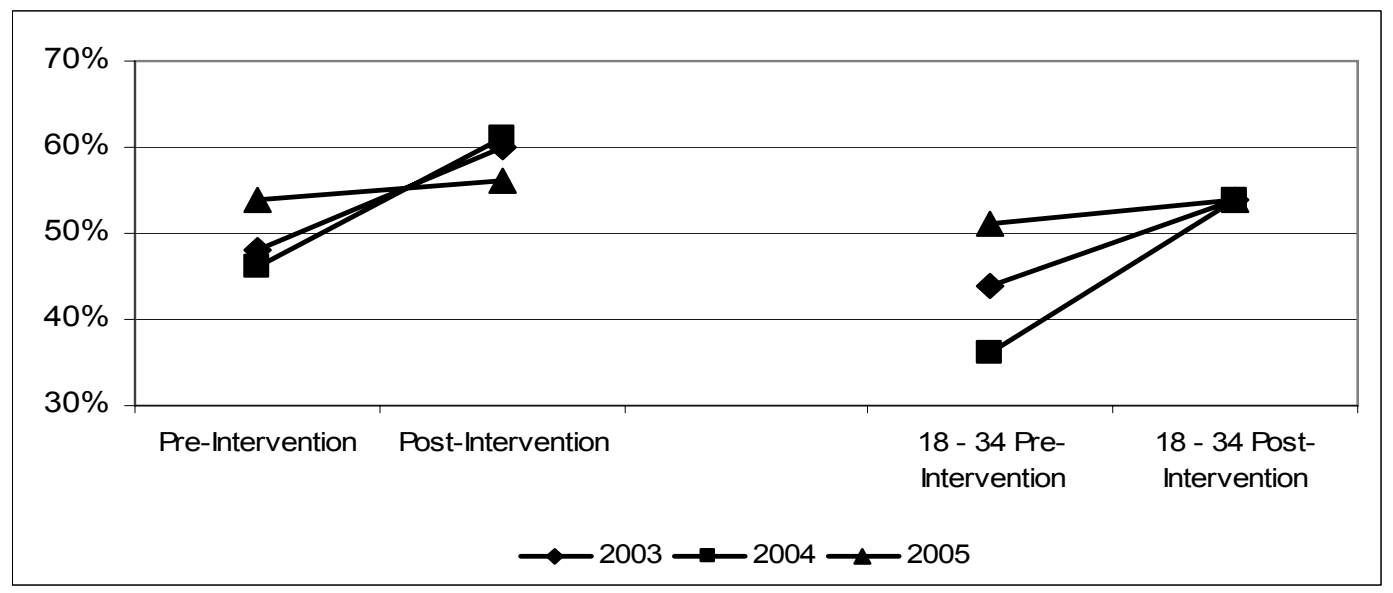

Figure 9. Unaided Awareness of the "You Drink and Drive. You Lose" Slogan: All Respondents and Respondents 18 to 34 Years Old

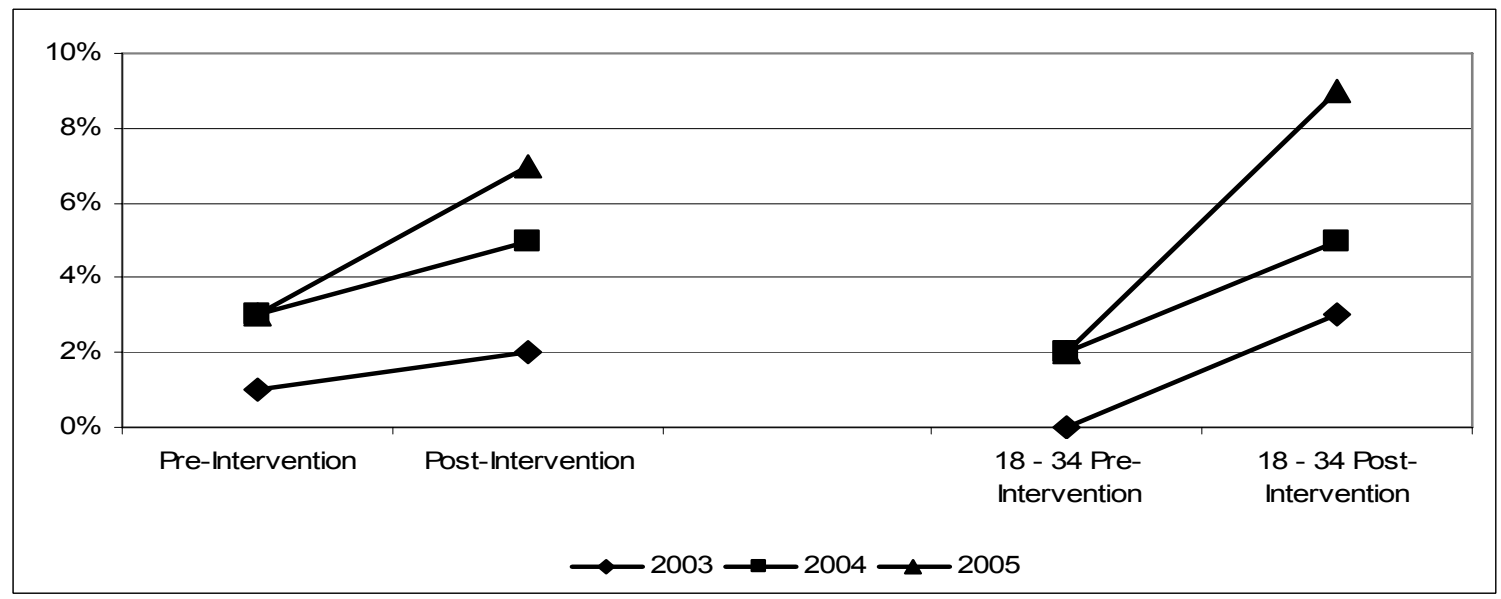

Recall and Recognition of the State and National Slogans: The proportion of respondents who were able to recall (without any prompts) the national slogan. "You Drink and Drive, You Lose" without any assistance, or unaided, was negligible. However, as Figure 9 shows, recall did increase in all three comparisons, from 1 to 2 percent during the 2003 crackdown and from 3 to 5 percent during the 2004 crackdown. Unaided recall increased significantly from 3 to 7 percent in the 2005 crackdown $(p<.01)$. Results were similar among younger respondents 18 to 34 years old. Their unaided recall increased from 0 to 3 percent during the 2003 crackdown, from 2 to 5 percent during the 2004 crackdown, and from 2 to 8 percent during the 2005 crackdown. None of these 
changes was statistically significant. Overall, there was a ratcheting effect with higher baseline measures for recalling the national slogan "You Drink and Drive, You Lose" after each mobilization. In addition, younger respondents had an overall lower ability to recall the slogan compared to all respondents.

As Figure 10 shows, the proportion of all respondents that recalled the State slogan "Checkpoint Strikeforce" was negligible. During the 2003 Crackdown, unaided recall remained 0 percent, and during the 2004 and 2005 unaided recall remained flat at 1 percent before and after each crackdown, The proportion of 18- to 34-year-old respondents that recalled the State slogan increased from 0 to 1 percent during the 2003 crackdown, and increased from 0 to 2 percent during the 2005 crackdown. However unaided awareness of the "Checkpoint Strikeforce" slogan decreased from 2 to 0 percent during the 2004 crackdown. None of these changes were statistically significant.

Figure 10. Recall of the State "Checkpoint Strikeforce" Slogan: All Respondents and Respondents 18 to 34 Years Old

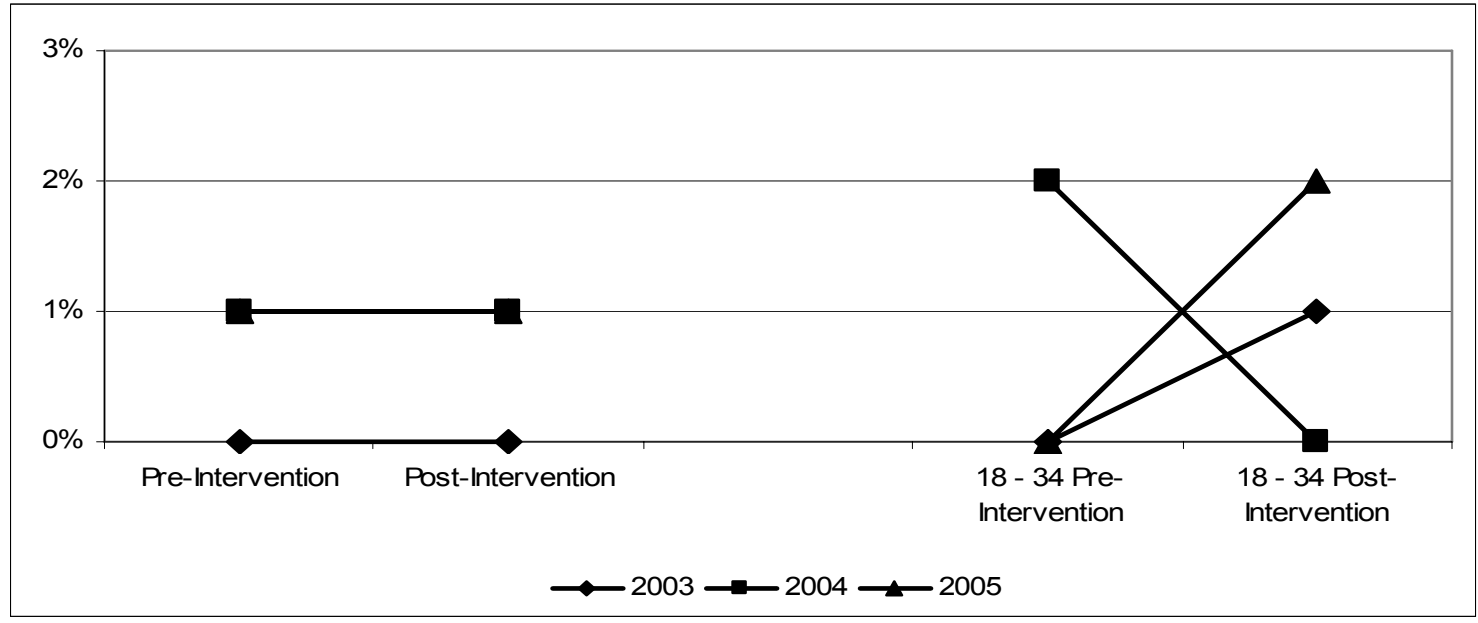

Figure 11. Recognition of "You Drink and Drive. You Lose": All Respondents and Respondents 18 to 34 Years Old

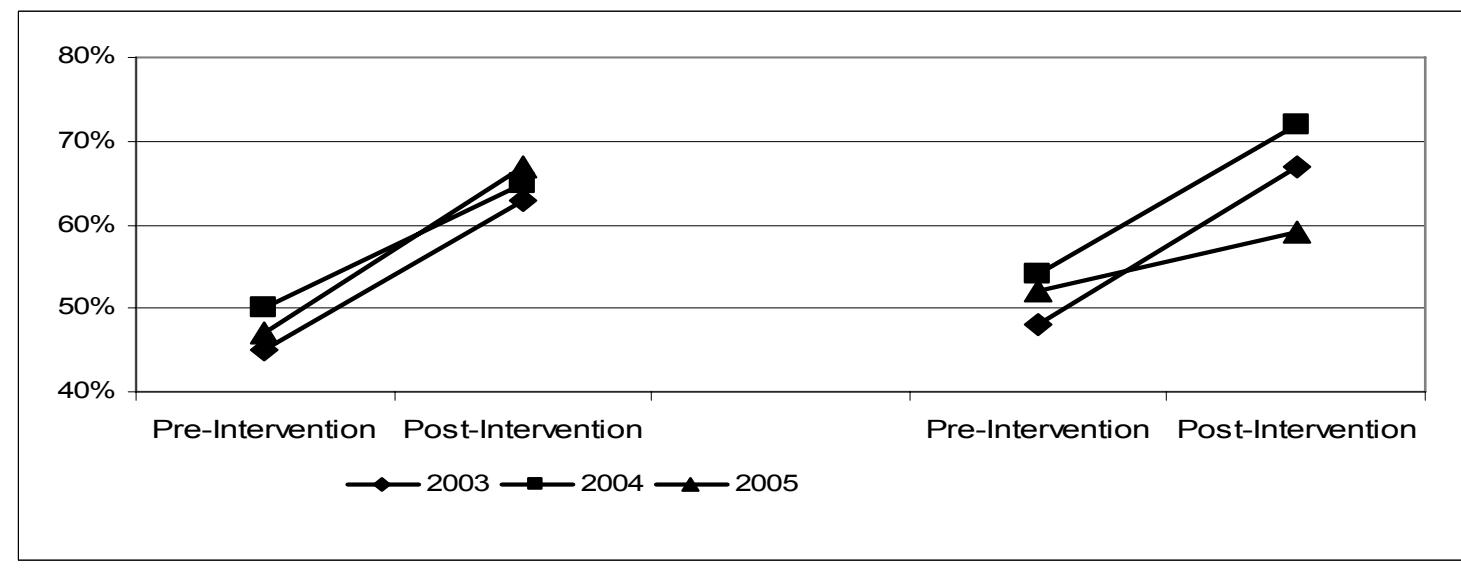

If spontaneous recall of the slogan did not occur, respondents were prompted with the slogan and asked if they recognize the slogan. The proportion of respondents, who recognized "You Drink and Drive, You Lose" as something they had seen or heard within the past 30 days, increased significantly from 45 to 63 percent during the 
2003 crackdown $(p<.01)$; from 50 to 65 percent during the 2004 crackdown $(p<.01)$, and from 47 to 67 percent during the 2005 crackdown $(p<.01)$. Similarly, the proportion of younger respondents 18 to 34 years old who recalled this slogan also increased from 48 to 67 percent during the 2003 crackdown $(p<.01)$, from 54 to 72 percent during the 2004 crackdown $(p<.01$ ), and from 52 to 59 percent during the 2005 crackdown (Figure 11). Overall, when provided with a prompt, younger respondents were better able to recognize the slogan compared to all respondents.

As Figure 12 shows, the amount who recalled the State slogan "Checkpoint Strikeforce" when prompted with the slogan increased across all three crackdown periods from 12 to 21 percent during the 2003 crackdown, from 14 to 19 percent during the 2004 crackdown, and from 16 to 18 percent during the 2005 crackdown. However, none of these changes was statistically significant. The pattern of data was similar among 18- to 34-year-old respondents. The proportion of younger respondents significantly increased their aided recall of the "Checkpoint Strikeforce" slogan from 11 to 26 percent during the 2003 crackdown $(p<.01)$. However, the increase in recall from 16 to 20 percent during the 2004 crackdown and the increase from 15 to 18 percent during the 2005 crackdown were not statistically significant.

Figure 12. Recognition of the "Checkpoint Strikeforce" Slogan: All Respondents and Respondents 18 to 34 Years Old

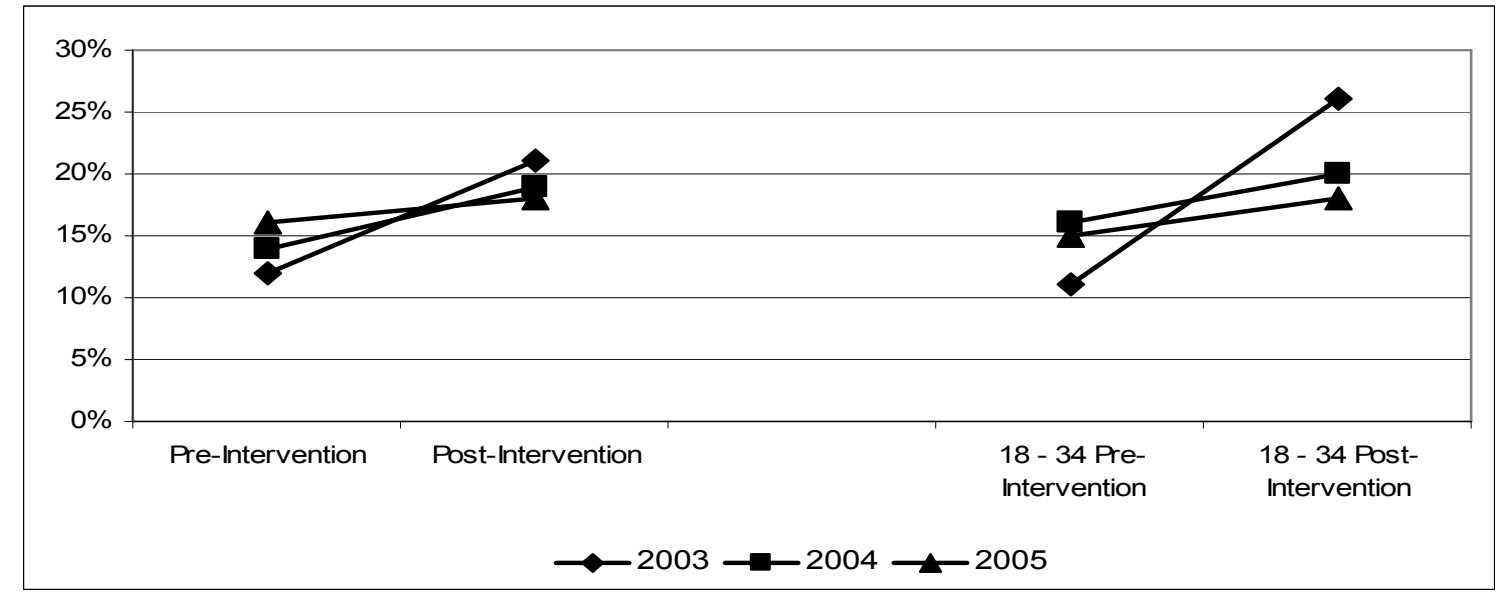

Recall Seeing a Particular Ad: The proportion of respondents who recalled having seen a particular ad on TV recently increased significantly in all three comparisons: from 15 to 51 percent during the 2003 crackdown $(p<$ .01 ), from 24 to 52 percent during the 2004 crackdown $(p<.01)$, and from 24 to 34 percent during the 2005 crackdown $(p<.01)$. The pattern of data was similar for 18- to 34-year-old respondents. Their recall increased significantly from 16 to 59 percent during the 2003 crackdown $(p<.01)$ and from 27 to 56 percent during the 2004 crackdown $(p<.05)$. However, the percent change from 31 to 40 percent during the 2005 crackdown was not statistically significant. 
Figure 13. Recall Seeing a Certain Ad: All Respondents and Respondents 18 to 34 Years Old

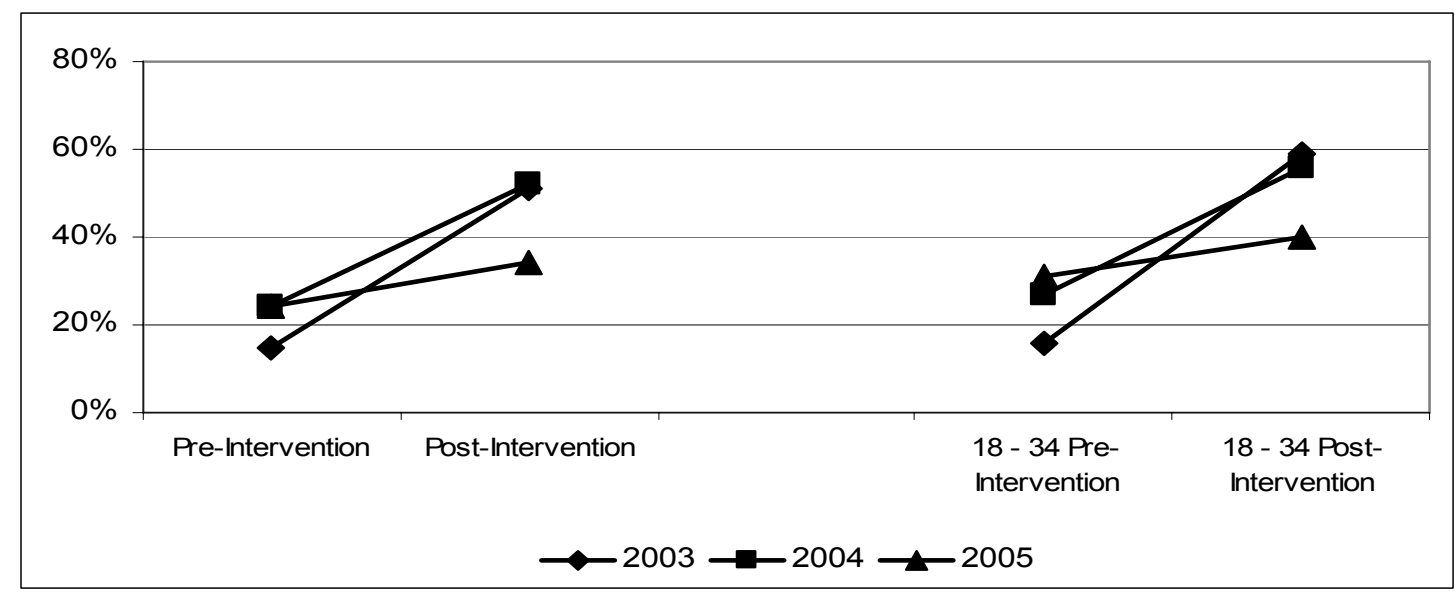

BEHAVIOR

The ultimate goal of any drinking and driving intervention program is to decrease the number of people who drive while impaired. Once awareness about the problem increases, it is hoped that individuals will change their behavior.

Drove Within Two Hours of Drinking: As Figure 14 indicates, the proportion of respondents who in the last 30 days had driven a motor vehicle within two hours after drinking an alcoholic beverage decreased from 18 to 13 percent during the 2003 crackdown period, from 18 to 17 percent during the 2005 crackdown period, but increased from 16 to 17 percent during the 2004 crackdown period. However, none of these changes were statistically significant. The pattern of data was similar among 18- to 34-year-old respondents. The absence of any changes from pre to post may be that there was a "dilution" of the effect given that the telephone survey samples were drawn from areas that included low levels of media and enforcement activities during the crackdown (as well as the high-enforcement areas).

Figure 14. Drove Within Two Hours of Drinking: All Respondents and Respondents 18 to 34 Years Old

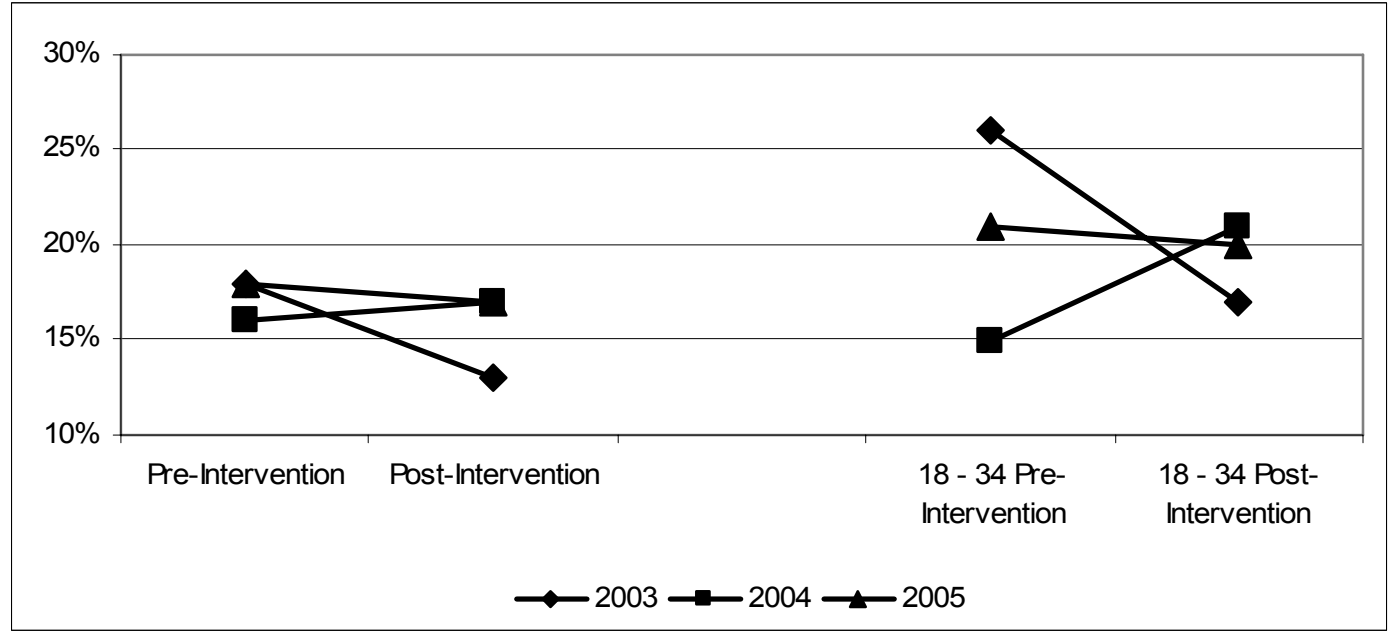


Times Driven After Drinking: Of the respondents who, in the last 30 days, admitted to driving within two hours after drinking alcohol, the mean number of days decreased in all three comparisons; from 3.6 to 3.5 days during the 2003 crackdown, from 4.1 to 3.8 days during the 2004 crackdown, and from 6.3 to 4 days during the 2005 crackdown (Figure 15). However, none of these changes were statistically significant. Among 18- to 34-year-old respondents, the mean number of times people drove within two hours of drinking alcohol increased from 2.6 to 4 days during the 2003 crackdown, and decreased from 3.2 to 2.9 days during the 2004 crackdown and from 3.9 to 3.3 days during the 2005 crackdown. Again, these changes were not statistically significant. This data suggests that the targeted younger respondents admit to driving within two hours after drinking less than all respondents.

\section{Figure 15. Mean Number of Days People Drove Within Two Hours After Drinking} During the Past 30 Days: All Respondents and Respondents 18 to 34 Years Old

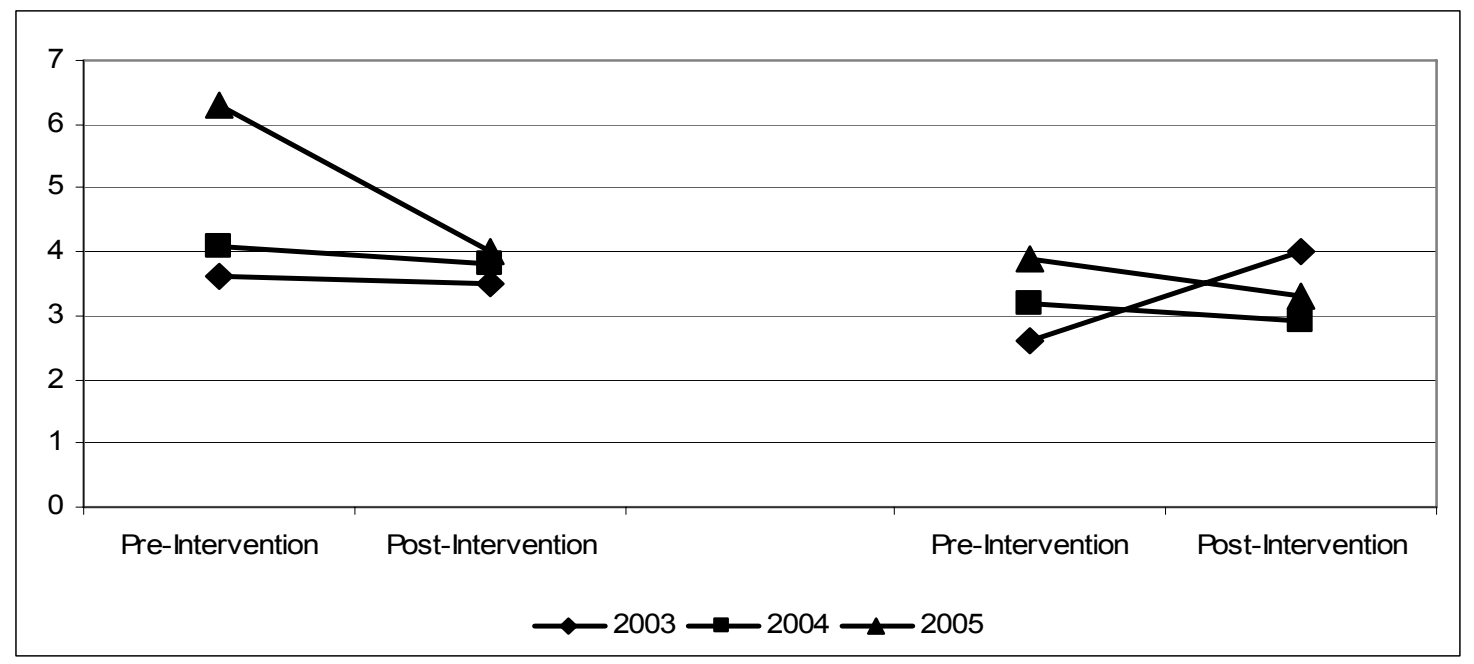

Driving When Had Too Much to Drink: As Figure 16 indicates, the proportion of respondents who admitted to driving in the past 30 days when they thought they had too much to drink increased from 8 to 9 percent during the 2003 crackdown and from 9 to 12 percent during the 2004 crackdown, and then decreased from 12 to 6 percent during the 2005 crackdown. None of the percent changes were statistically significant. The pattern of data was similar among 18- to 34-year-old respondents. Both before and after each crackdown, more young respondents admitted to driving after drinking too much compared to all respondents. There is no clear pattern to this data which might suggest a relationship between the admitting to driving after drinking too much and enforcement of media activities. However, this might be confounded because the telephone survey samples represent target and non-target areas in West Virginia with varying levels of media and enforcement activities. 
Figure 16. Admitted to Driving After Drinking Too Much: All Respondents and Respondents 18 to 34 Years Old

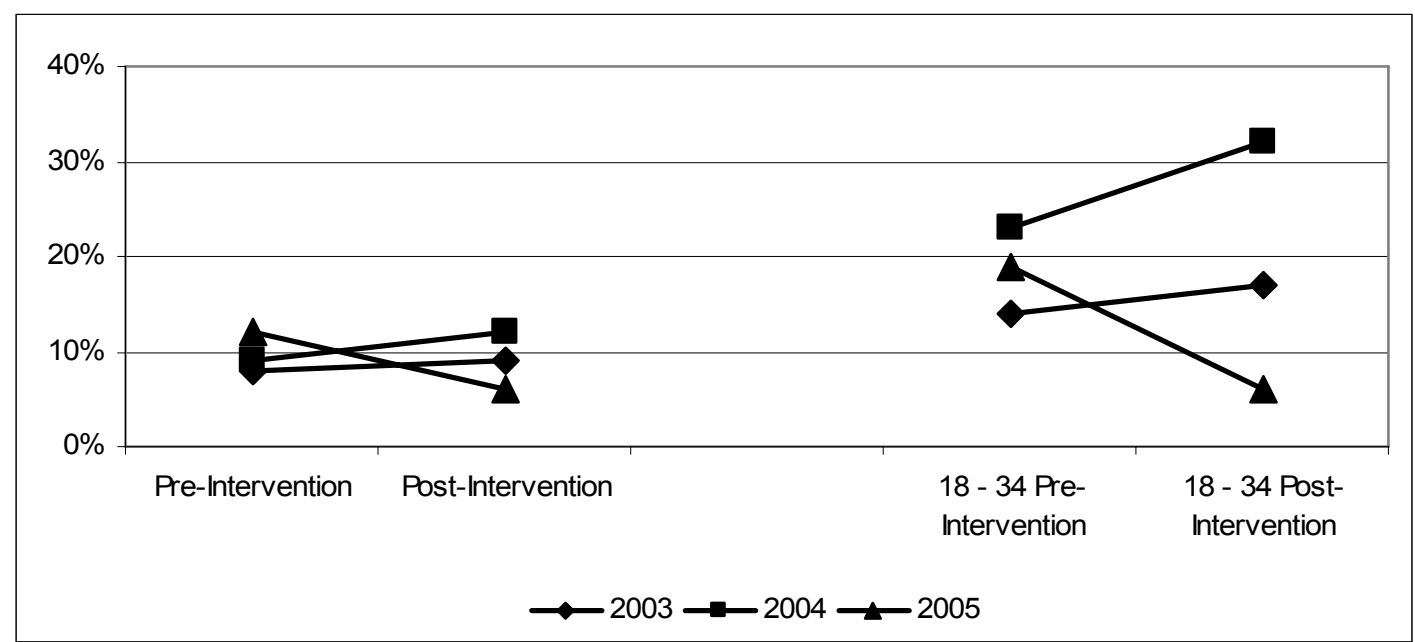

\section{PERCEPTIONS}

A primary purpose of drinking and driving intervention campaigns is to increase the public's perception that law enforcement agencies take the problem seriously. And if caught, those who drive impaired will not go unpunished. While it is hoped that drivers would not drink and drive as a result of successful intervention campaigns, it may be that they need the added deterrent of a police presence.

Overall Likelihood of Being Stopped: As Figure 17 shows, there is no clear pattern or trend in the respondents' perception of being stopped by police during each crackdown in West Virginia. The proportion of respondents who thought it was very likely that the police would stop them if they were driving when their BAC levels were higher than the law allows, increased from 21 to 25 percent during the 2003 crackdown, as well as from 27 to 28 percent during the 2005 crackdown. However, the proportion decreased significantly from 28 to 22 percent during the 2004 crackdown $(p<.05)$. Among 18- to 34-year-old respondents, the proportion increased from 21 to 31 percent during the 2003 crackdown, decreased from 37 to 28 percent during the 2004 crackdown, and remained at 28 percent during the 2005 Crackdown. Despite the mixed results, which show both increased and decreased likelihood of being stopped by police during a crackdown, it appears more of the younger respondents perceived a likelihood of being stopped by police than all respondents did. Again, it is important to recall that the telephone survey samples were drawn from targeted and non-targeted areas in West Virginia that had varying levels of media and enforcement activities. 
Figure 17. Overall Likelihood of Being Stopped by Police: All Respondents and Respondents 18 to 34 Years Old

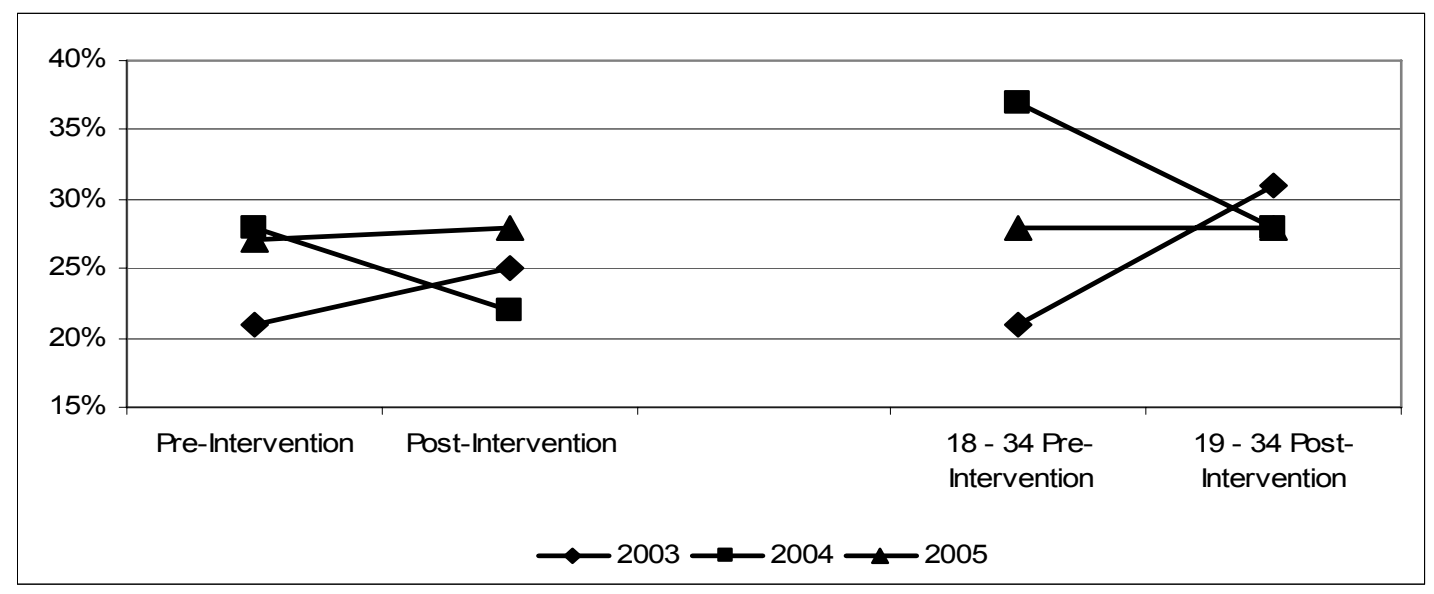

Increased Likelihood of Being Stopped Now: As Figure 18 shows, the proportion of respondents who thought a driver who had been drinking was more likely to be stopped by the police now, than 30 days ago increased significantly from 27 to 34 percent during the 2003 crackdown $(p<.05)$. In 2004, this proportion decreased from 29 to 28 percent and increased in 2005 from 27 to 28 percent. However, these were not statistically significant. Among 18- to 34-year-old respondents, the proportion increased in all three comparisons; from 30 to 33 percent in 2003, from 27 to 35 percent in 2004, and from 25 to 28 percent in 2005. None of these changes was statistically significant. Overall, it appears that the largest gains made in the public perception of the likelihood of a driver who had been drinking being stopped by the police now were during the first crackdown. This pattern was the same for the target younger respondents.

Figure 18. Increased Likelihood of Being Stopped by Police Now: All Respondents and Respondents 18 to 34 Years Old

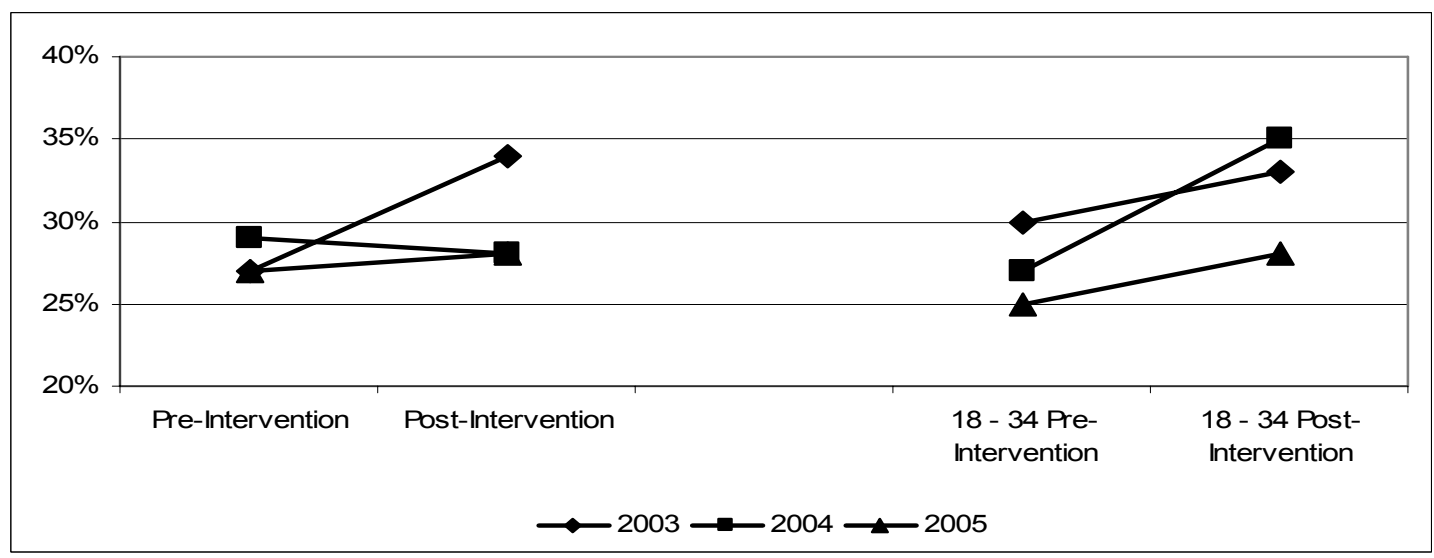


Enforcement of Drinking and Driving Laws: The proportion of respondents who felt it was very important to enforce drinking and driving laws remained at 84 percent during the 2003 crackdown, increased from 83 to 86 percent during the 2004 crackdown, and decreased from 83 to 82 percent during the 2005 crackdown (Figure 19). None of these changes were statistically significant. Support among the younger respondents was less enthusiastic. Among 18- to 34-year-old respondents the proportion decreased from 82 to 81 percent during the 2003 crackdown and from 83 to 74 percent during the 2005 crackdown, but increased from 78 to 84 percent during the 2004 crackdown. None of the percent changes were statistically significant.

Figure 19: Enforcement of Drinking and Driving Laws: All Respondents and Respondents 18 to 34 Years Old

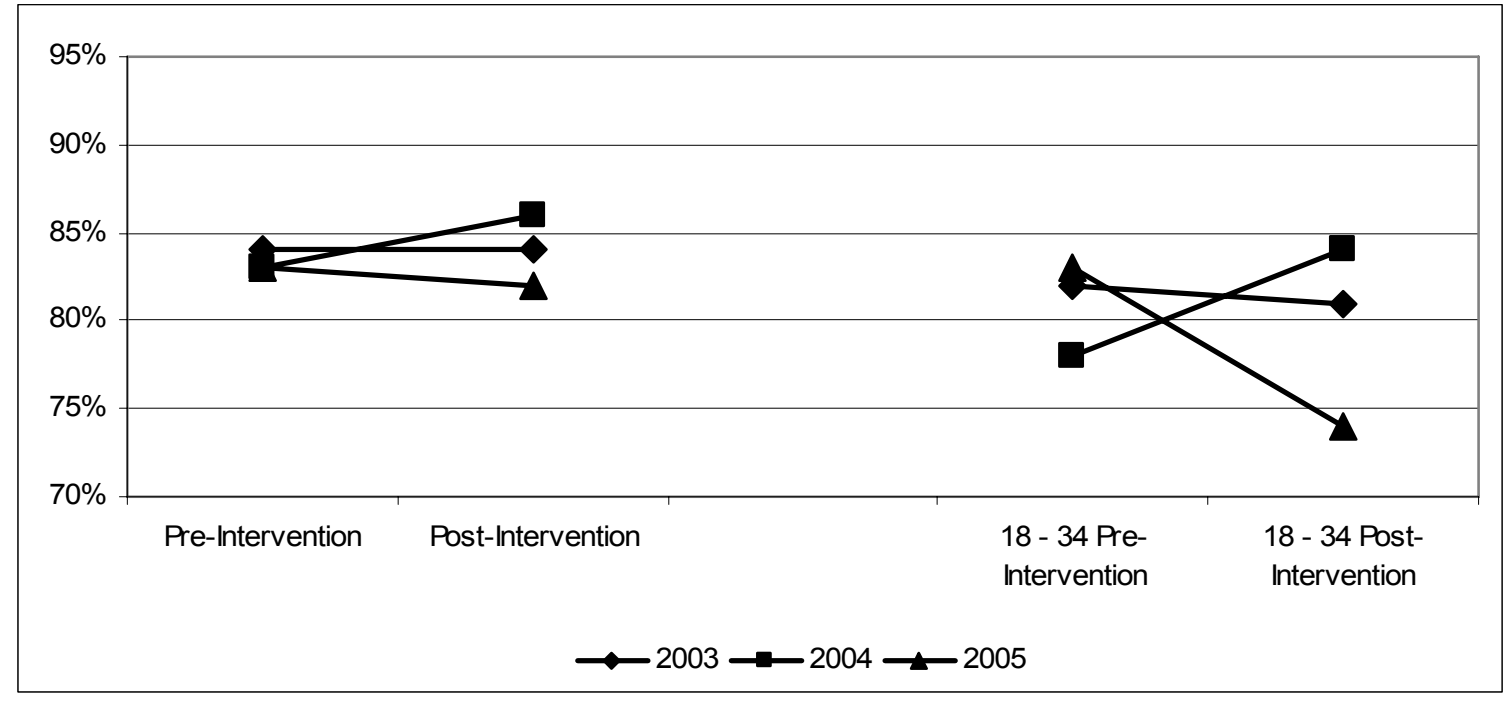

\section{SUMMARY AND CONCLUSIONS}

West Virginia's impaired driving high-visibility enforcement campaign for targeted counties across the State was designed to reduce impaired driving and ultimately, alcohol-related crash fatalities. The campaign focused on increasing enforcement, especially during holiday periods, and on a sustained basis between holiday crackdowns, and enhancing publicity to increase awareness about the enforcement activity. Results from DMV office surveys for targeted counties indicated that significantly more drivers heard the enforcement-based media messages and drivers reported going through significantly more sobriety checkpoints. The targeted counties had an average of 21.5 sobriety checkpoints each from June 2003 through December 31, 2005, while the non-targeted counties had an average of just 4.73 sobriety checkpoints each during the same period. On average, West Virginia spent about 62 cents per resident each year from 2003 through 2005 on its publicity and enforcement campaign to combat drinking and driving, particularly in the six targeted counties of Berkeley (Martinsburg), Marion (Fairmont), Ohio (Wheeling), Raleigh (Beckley), and Wood (Parkersburg). 
Law enforcement agencies put on a large number of sobriety checkpoints as the campaign progressed, with a particularly large number of sobriety checkpoints held in targeted counties as compared to non-targeted counties. The increased number of checkpoints accompanied by the extensive media campaign was designed to serve as a deterrent to those who may have otherwise decided to drink and drive, and ultimately lead to fewer alcohol-related fatalities on roads in the targeted counties of West Virginia.

The campaign also achieved its ultimate goal: significantly reducing the alcohol-related fatality trend in the targeted counties. The reduction in alcohol-related fatalities resulted in saving an estimated 18 lives over an 18month period. 


\section{REFERENCES}

Lacey, J.H., Ferguson, S.A., Kelley-Baker, T., \& Rider, R.P. (2005). Low-manpower checkpoints: Can they provide effective DUI enforcement in small communities? Arlington, VA: Insurance Institute for Highway Safety.

Lacey, J. H., Jones, R. K., \& Smith, R. G. (1999). Checkpoint Tennessee: Tennessee's Statewide Sobriety Checkpoint Program. Final Report, contract no. DTNH22-94-C-05064. Report Number DOT-HS-808-841. Washington, DC: National Highway Traffic Safety Administration.

Levy, M., Compton, R., \& Dienstfrey, S. (2004). Public Perceptions of the July 2003 You Drink \& Drive. You Lose. Crackdown: Telephone Surveys Show the Media Campaign Reaches Target Audience. Report Number DOT HS 809 708. Washington, DC: National Highway Traffic Safety Administration.

NHTSA (2003). Traffic Safety Facts 2003. Report Number DOT HS 809761. Washington, DC: National Highway Traffic Safety Administration.

Wells, J.K., Preusser, D.F., \& Williams, A.F. Enforcing Alcohol-Impaired Driving and Seat Belt Use Laws, Binghamton, New York. Journal of Safety Research, 1992, 23, 63-71.

Zwicker, T. J., Chaudhary, N. K., Maloney, S., \& Squeglia, R. (2007). Connecticut's Impaired Driving Publicity and Enforcement Campaign. Final report, contract no. DTNH22-98-D-45079. Report Number DOT-HS-810-689 Washington, DC: National Highway Traffic Safety Administration. 
Appendix A: West Virginia DMV Office Survey for the Impaired Driving High-Visibility Enforcement Evaluation 
This Driver Licensing Office is assisting in a study about Alcohol in West Virginia. Your answers to the following questions are voluntary and anonymous. Please complete the survey and then put it in the drop box.

1. Your sex: Male Female

2. Your age: $16-20$ $21-25$ 26-39 $40-49$ $50-59$ 60 Plus

3. Your race: White Black Asian Native American Other

4. Are you of Spanish/Hispanic origin? Yes No

5. Your Zip Code:

6. How often do you use seat belts when you drive or ride in a car, van, sport utility vehicle or pick up? Always Nearly always Sometimes Seldom Never

7. In the past $\mathbf{3 0}$ days, how many times have you driven a motor vehicle within $\mathbf{2}$ hours after drinking alcoholic beverages? (number of times)

8. What do you think the chances are of getting arrested if you drive after drinking?

_ Always _ Nearly Always__ Sometimes_ _ Seldom_ Never

9. Compared with 3 months ago, are you now driving after drinking? (check one)

_ More often L_ Less often__ _ About the same _ _ Do not drive after drinking

10. Do you think the police enforce the drinking and driving laws:

_ Very strictly _ _ Somewhat strictly__ Not very strictly _ _ Rarely _ _ Not at all

11. Do you think the penalties for alcohol impaired driving are:
Too strict
About right
Not strict enough
Don't know

12. In the past $\mathbf{3 0}$ days, have you gone thru a police checkpoint targeting alcohol- impaired drivers? Yes No

13. Have you recently read, seen or heard anything about alcohol impaired driving (or drunk driving) in West Virginia? Yes No

If yes, where did you see or hear about it? (Check all that apply):
Newspaper
Radio
TV
Poster
Brochure Police checkpoint Other

14. Do you know the name of any alcohol-impaired driving enforcement program(s) in West Virginia?

(check all that apply):

Let Friends Drive Drunk
You Drink \& Drive, You Lose Please Step Away From Your Vehicle
Checkpoint Strikeforce

Friends Don't 
APPENDIX B: West Virginia Roadside Survey Data Collection Form 
Machine \#:__ Refused All

If subject pulled over, check all that apply: Warn_Belt Tckt_CPS_Oth Tckt_FST_DWI_Oth Arrest

Could Not Make Contact with Driver__ (still estimate age, sex, race, passengers, \& vehicle type below)

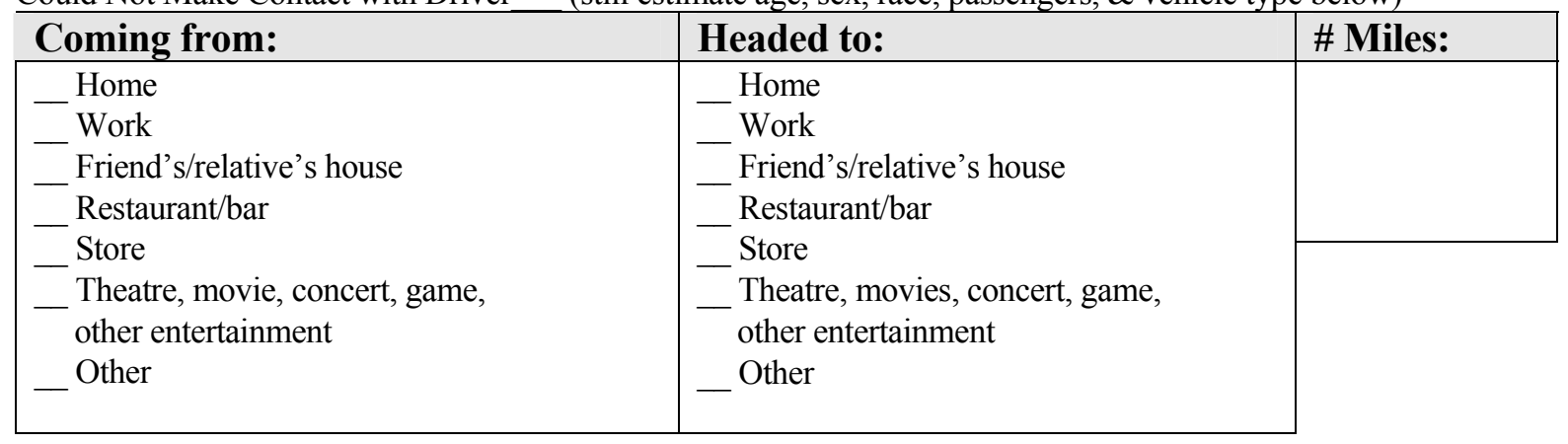

Ever been through a police checkpoint before? YES NO Day Night

In past 6 months besides this one? YES NO

Do you favor the use of checkpoints by police to enforce the law against drinking and driving?

YES NO Comments:

Within the past month, have you seen, heard or read about any special police efforts to enforce the law against drinking and driving? YES NO

If YES, where? TV Radio Newspaper Poster Brochure Other

\begin{tabular}{|c|cc|cc|}
\hline $\begin{array}{c}\text { Zip Code Where you } \\
\text { Live }\end{array}$ & Manually Sampled? & \multicolumn{2}{|c|}{ Took Alcohol Test? } \\
\hline & YES NO & YES & NO, refused \\
\hline
\end{tabular}

Estimate: get zip of subject if arrested-ask officer for zip on driver's license get State off plate if REFUSE ALL

\begin{tabular}{|c|c|c|c|c|}
\hline$\underline{\text { Age }}$ & $\underline{\text { Sex }}$ & $\underline{\text { Race }}$ & \# of Passengers & Type of vehicle \\
\hline $\begin{array}{r}16-24 \\
-25-34 \\
-35-49 \\
-50-64 \\
-\quad 65+\end{array}$ & $\begin{array}{r}\mathrm{M} \\
-\mathrm{F}\end{array}$ & $\begin{array}{l}\text { - White } \\
\text { - Black } \\
\text { - Asian } \\
\text { - Other } \\
\text { Hispanic } \\
\frac{\text { Yes }}{\text { No }}\end{array}$ & $\begin{array}{l}0 \\
-1 \\
-2 \\
-3 \\
-4 \\
-5 \\
-5 \\
\text { more }\end{array}$ & $\begin{array}{l}\text { Passenger car } \\
\text { - Pick-up truck } \\
\text { - Minivan } \\
\text { - Full-size van } \\
- \text { SUV } \\
- \text { Truck } \\
\text { - Other }\end{array}$ \\
\hline
\end{tabular}

Test \#:

Press small far right dot for the test \# for this person (if took test) and record here.

If DWI arrest, evidentiary BAC test: 
APPENDIX C: West Virginia Telephone Survey 
YOU DRINK AND DRIVE. YOU LOSE TELEPHONE SURVEYS

County:

Zip:

Metro Status:

Date :

CATI ID:

Interviewer:

Telephone Number:

Time Start:

Time End:

TOTAL TIME:

READ IN: STATE

\section{INTRODUCTION}

Hello, I'm calling for the U.S. Department of Transportation. We are conducting a national study of Americans' driving habits and attitudes. The interview is voluntary and your answers will be kept completely confidential and used for statistical purposes. It only takes about10 minutes to complete. [Please note that an agency may not conduct or sponsor, and a person is not required to respond to, a collection of information unless it displays a currently valid OMB control number. The OMB control number for this information collection is 2127-XXXX] Could we begin now?

Q1. First, including yourself, how many persons age 16 and older are living in this household at least half the time, even if they are not at home right now?

NUMBER OF ADULTS IN HOUSEHOLD

None........00 CONFIRM, THEN SCREEN OUT Q1

Refused......999

Q2. How many of these (NUMBER FROM Q1) persons drive a motor vehicle at least a few times a year?

NUMBER OF DRIVERS IN HOUSEHOLD

None........00 CONFIRM, THEN SCREEN OUT Q2

Refused......99

Q3. Even if they were not driving, how many of these (NUMBER FROM Q2)

drivers have had even a single beer, glass of wine or any other

alcoholic beverage in the past year? (They do not have to be regular

drinkers or persons who drive after drinking.)

NUMBER OF DRIVERS WHO EVER DRINK IN HOUSEHOLD

None........00 CONFIRM, THEN SCREEN OUT Q3

Refused......999 


\section{IF ONLY ONE IN Q3, ASK TO SPEAK TO THAT PERSON AND CONTINUE WITH Q5 IF MORE THAN ONE IN Q3, ASK Q4a}

Q4a. In order to select just one person to interview, could I speak to the youngest male DRIVER who has had a beer, glass of wine or other alcoholic beverage in the past year, age 16 and older?

IF NO MALE ASK: Could I speak to the youngest female DRIVER who has had a beer, glass of wine or other alcoholic beverage in the past year, age 16 and older?

ALTERNATE WORDING: Could I speak to that person?

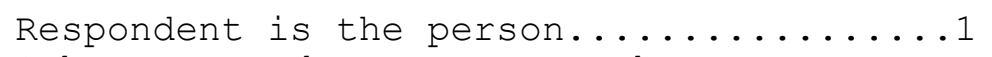

Other respondent comes to phone.............

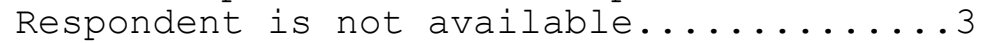

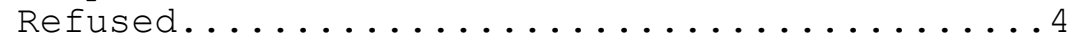

\section{SKIP TO $Q 6$ \\ SKIP TO Q5a \\ ARRANGE CALLBACK ASK Q4b}

Q4b. Would you please tell me why you do not want to do the interview?

TERMINATE

Q5a. Hello, I'm calling for the U.S. Department of Transportation. We are conducting a study of Americans' attitudes about driving and traffic safety. The interview is completely confidential and will take 5 minutes. Could we begin now?

CONTINUE INTERVIEW............

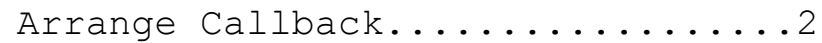

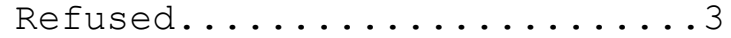

\section{SKIP TO 26 \\ CALLBACK \\ ASK Q5b}

Q5b. Would you please tell me why you do not want to do the interview?

TERMINATE

Q6. How often do you drive a motor vehicle? Almost every day, a few days a week, a few days a month, or a few days a year?

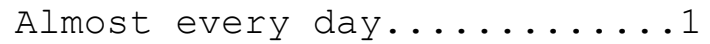

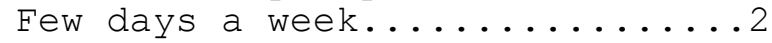

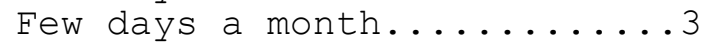

Few days a year.................

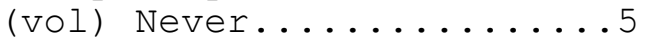

Other (SPECIFY) ............

(VOL) Don't know...........

(VOL) Refused.............

SCREEN OUT

Q7. Is the vehicle you drive most often a car, van, motorcycle, pickup truck, sport utility vehicle, or other type of truck? (NOTE: IF RESPONDENT DRIVES MORE THAN ONE VEHICLE OFTEN, ASK:) "What kind of vehicle did you LAST drive?"

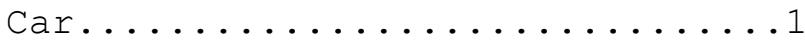

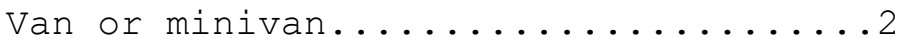

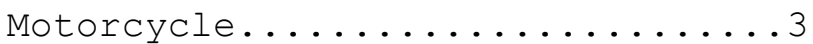

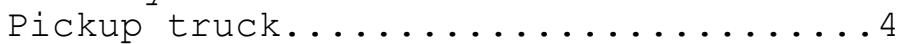

SKIP TO Q9a

Sport Utility Vehicle..........5

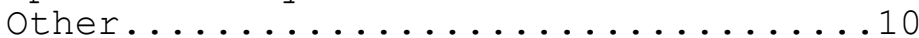

Other truck (SPECIFY) ..........11

(VOL) Don't know..............12

(VOL) Refused...............13 
Q8. When driving this (car/truck/van), how often do you wear your seat belt? [READ ANSWERS] [IF ASKED IF THIS APPLIES TO SHOULDER BELTS OR LAP BELTS SAY SHOULDER BELTS]

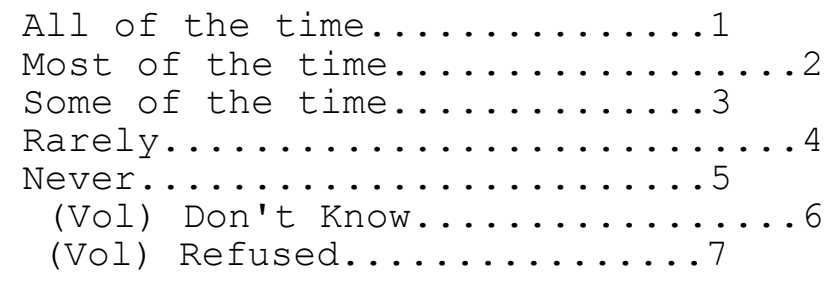

Q9a. Now I'm going to ask you a few questions about alcohol use. During the past 30 days have you had at least one drink of any alcoholic beverage, including liquor, beer, wine or wine coolers?

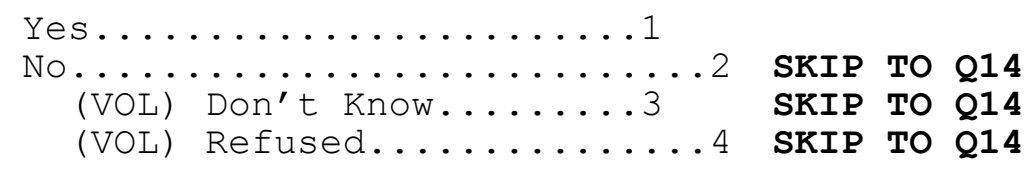

Q9b. How many days out of the past 30 days did you drink ANY alcoholic beverages (including beer, wine, wine coolers, mixed drinks or liquor)?

(Range=01-30) DON'T KNOW=31 REFUSED=32

Q10a. During the past 30 days, have you driven a motor vehicle within two hours after drinking any alcoholic beverages, even if you had only a little?

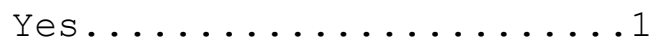

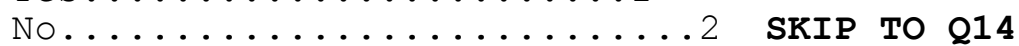

(VOL) Don't Know....... SKIP TO Q14

(VOL) Refused..........4 SKIP TO Q14

Q10b. How many days out of the past 30 days did you drive within two hours after drinking any alcoholic beverages?

$$
\text { (Range=01-30) DON'T KNOW }=31 \quad \text { REFUSED }=32
$$

\section{IF $\mathrm{Q} 10 \mathrm{~b}=31$ OR 32 , THEN SKIP TO $\mathrm{Q} 14$}

Q11. On the most recent occasion when you drove within two hours after drinking alcoholic beverages, how many drinks (of beer, wine, liquor) did you have?

ENTER NUMBER of DRINKS __ (01-90)

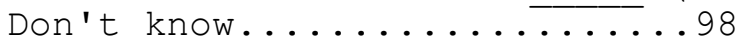

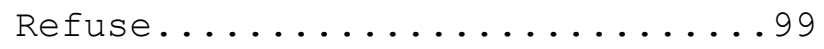

Q12a. In the past 30 days, did you drive when you thought you had too much to drink?

Yes....................

No................. SKIP TO $\mathbf{Q 1 4}$

(VOL) Don't know........ SKIP TO Q14

(VOL) Refused...........4 SKIP TO Q14 
Q12b. About how many times in the past 30 days did you drive when you thought you had too much to drink?

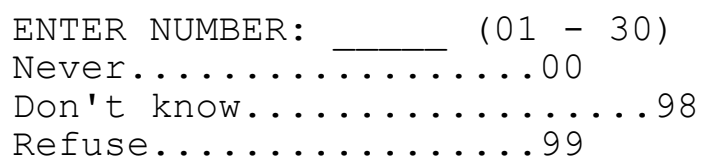

Q13. Compared to other months during the past year, would you say that the number of days you drove after drinking alcohol was (lower/higher than usual, lower) than usual or the same as usual during the past 30 days? [IF $Q 10 b=0$ THEN SAY "LOWER"; IF $Q 10 \mathrm{~b}>0$ THEN SAY "HIGHER THAN USUAL,
LOWER"]

Higher Than Usual......1

Lower Than Usual..........2

Same as Usual..........

(VOL) Don't Know......4

(VOL) Refused.........5

Q14. In the past 30 days, have you seen police on the roads you normally drive [READ LIST]

More often than usual.........

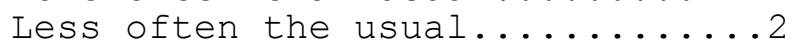

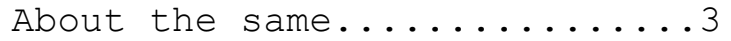

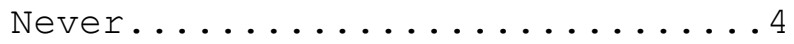

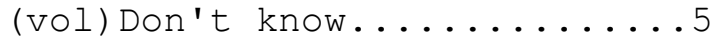

(vol) Refuse................6

Q15. Suppose you drove a motor vehicle after drinking alcohol, and the amount of alcohol in your body was more than what the law allows for drivers. How likely is it that the police would stop you? Would the police be.........?

Very Likely To stop You, ..............

Somewhat Likely To Stop You, or..........

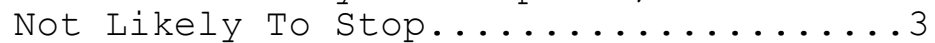

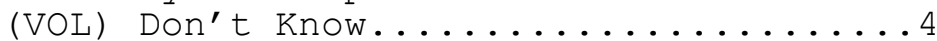

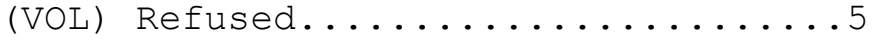

Q16. Do you think the chances of being stopped have changed in the past month? That is, compared to a month ago, do you think a driver who had been drinking is more likely, less likely or about as likely to be stopped by the police?

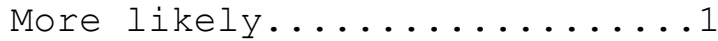

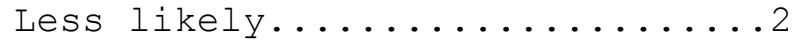

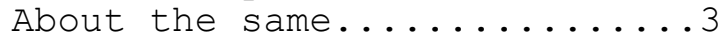

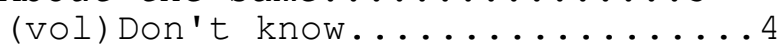

(vol) Refuse................

Q17a Now, I would like to ask you a few questions about educational or other types of activities. In the past 30 days, have you seen or heard any messages that encourage people to avoid driving after drinking? This could be public service announcements on TV, messages on the radio, signs on the road, news stories, or something else.

Yes...........

No...........2 SKIP TO Q18a

Don't know......3 SKIP TO Q18a

Refused........4 SKIP TO Q18a 
Q17b. Where did you see or hear these messages?

[DO NOT READ--MULTIPLE RESPONSE]

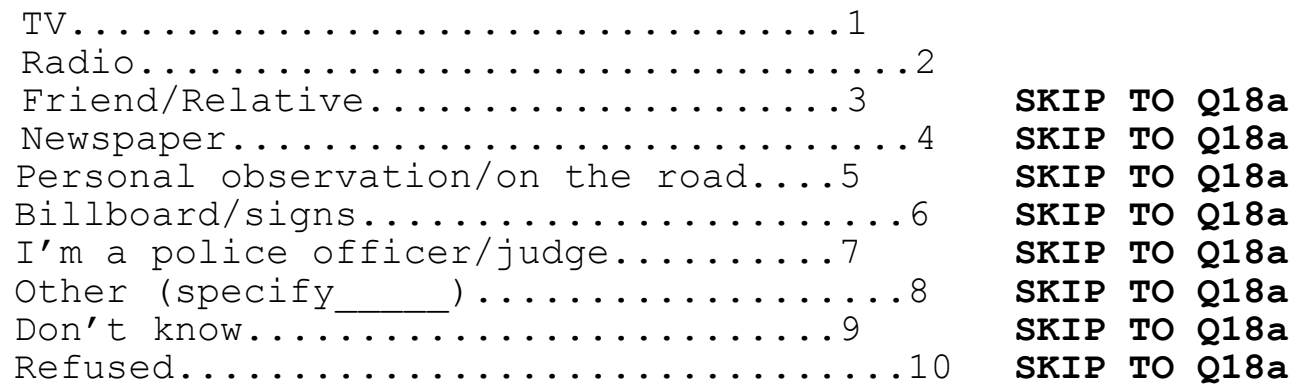

Q17C. Was the (TV/radio) message a commercial (or advertisement), was it part of a news program, or was it something else? [MULTIPLE RECORD]

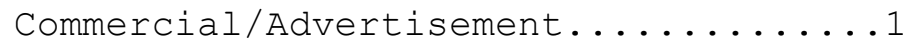

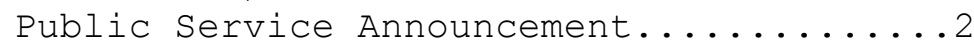

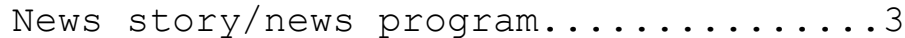

Something else (specify): $\ldots \ldots 4$

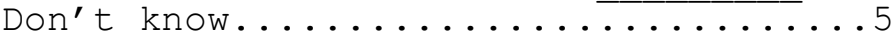

Q.17d Would you say that the number of these messages you have seen or heard in the past 30 days that encourage people to avoid driving after drinking is more than usual, fewer than usual, or about the same as usual?

More than usual..........

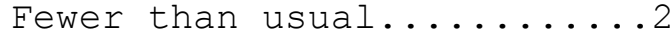

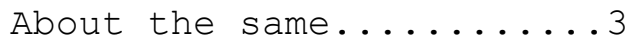

Don't know.............4

Q18a. Yes or No--in the past 30 days, have you seen or heard of any special effort by police to reduce driving under the influence or drunk driving in your community?

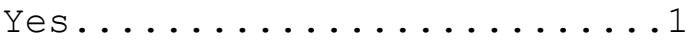

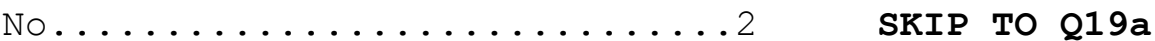

(Vol) Don't know.................................... SKIP TO Q19a

(Vol) Refused............... SKIP TO Q19a

Q.18b Where did you see or hear about that special effort?

[DO NOT READ--MULTIPLE RESPONSE]

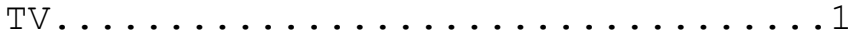

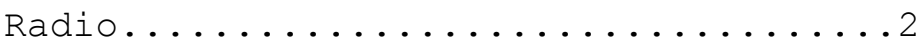

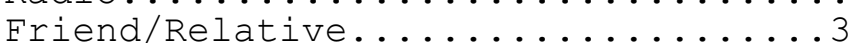

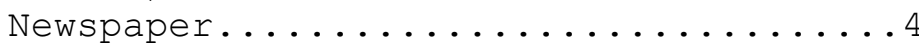

Personal observation/on the road...5

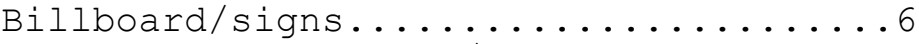

I'm a police officer/judge..........

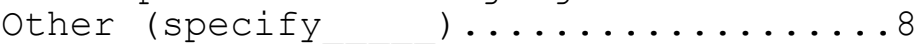

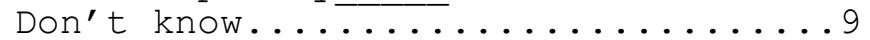

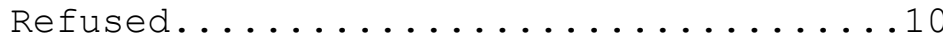

SKIP TO $Q 19 a$
SKIP TO Q19a
SKIP TO Q19a
SKIP TO Q19a
SKIP TO Q19a
SKIP TO Q19a
SKIP TO Q19a
SKIP TO Q19a


Q18c. Was the (TV/radio) message a commercial (or advertisement), was it part of a news program, or was it something else? [MULTIPLE

RECORD ]

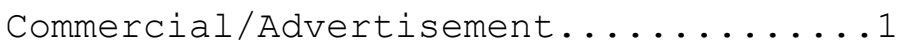

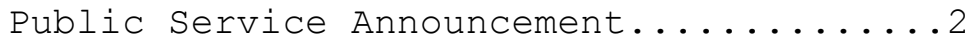

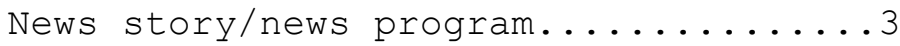

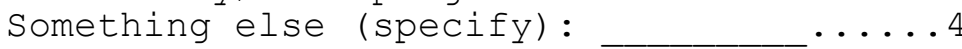

Don't know....................

Q19a. In the past 30 days, have you seen or heard anything about police setting up checkpoints or other enforcement efforts to catch drivers who were driving while under the influence of alcohol or driving drunk?

Yes...............

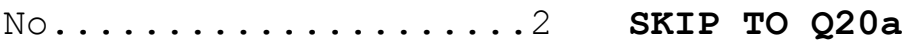

(Vol) Don't know....3 SKIP TO Q20a

(Vol) Refused.......4 SKIP TO Q20a

Q19b. In the past 30 days, did you personally drive past, or drive through, a police checkpoint or other enforcement effort set up to catch drivers who were driving while under the influence of alcohol or driving drunk?

Yes...............

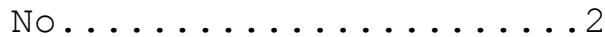

(Vol) Don't know.....3

(Vol) Refused...........4

Q20a. Do you know the name or slogan of any enforcement program(s) that prevent driving under the influence or drunk driving in State]?

Yes.........

No......... SKIP TO Q20c

Don't know...3 SKIP TO Q20c

Refuse.......4 SKIP TO Q20c 


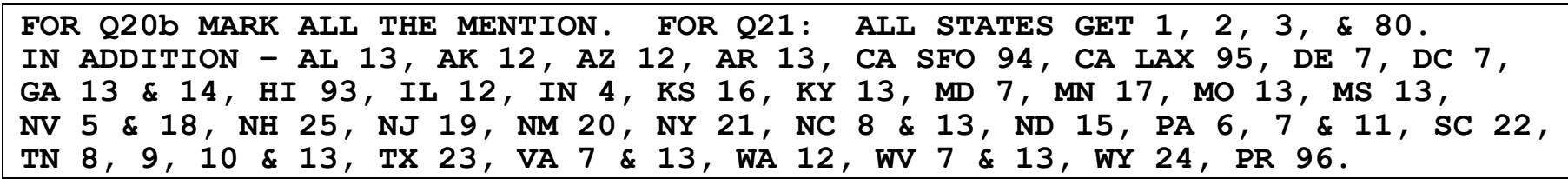

220b. What was the slogan or program called? [MULTIPLE MENTION]

1. Friends don't let friends drive drunk..... (PUNCH "1") (All)

2. You Drink and Drive. You Lose............(PUNCH "2") (All)

3. Get the keys..................... (PUNCH "3") (All)

4. Operation Pullover................. (PUNCH "4")

5. Why Risk It..................... (PUNCH "5")

6. Please Step Away from Your Vehicle. DUI... (PUNCH "6")

7. Checkpoint StrikeForce................ PUNCH "7")

8. Booze It and Lose It................ (PUNCH " 8 ")

9. Step Away From your Vehicle.............. (PUNCH "g")

10. Checkpoint Tennessee................ (PUNCH "10")

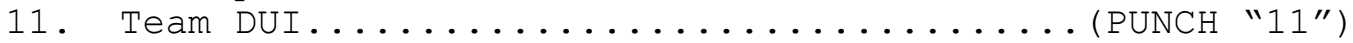

12. Drive Hammered, Get Nailed............. (PUNCH "12")

13. Border to Border.................... (PUNCH "13")

14. Operation Zero Tolerance..................................... "14")

15. Do Buckle - Don't Booze................ (PUNCH "15")

16. There's NO EXCUSE for Drunk Driving....... (PUNCH "16")

17. Get a Designated Driver. Or Pay the Price. (PUNCH "17")

18. Arrive Alive! Don't Drink and Drive....... (PUNCH "18")

19. HOLD FOR NJ..................... (PUNCH "19")

20. Don't Drink \& Drive or We Will stop You... (PUNCH "20")

21. Think Safe, Drive Sober.............. (PUNCH "21")

22. Sober or SLAMMER................. (PUNCH "22")

23. Santa's Coming, Don't Hit Him............ (PUNCH "23")

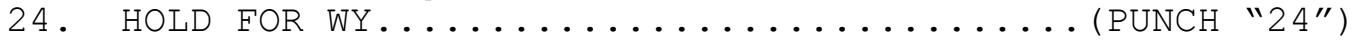

25. DUI Hunters..................... (PUNCH "25")

26. MADD/Mothers Against Drunk Driving........ (PUNCH "26")

27. DARE/Drug Abuse Resistance Education...... (PUNCH "27")

28. SADD/Students Against Drunk Driving....... (PUNCH "28")

29. Don't drink and drive....................................

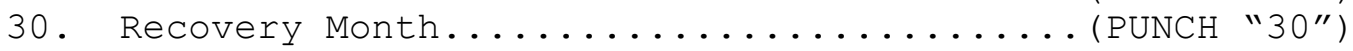

93. Keoki Kool (designated driver)........... (PUNCH "93")

$(A L L)$

94. Avoid the $23 \ldots \ldots \ldots \ldots \ldots \ldots \ldots \ldots \ldots \ldots \ldots \ldots \ldots \ldots$ (PUNCH " $94 "$ ")

95. Avoid the $50 \ldots \ldots \ldots \ldots \ldots \ldots \ldots \ldots \ldots \ldots \ldots \ldots \ldots \ldots \ldots$ (PUNCH "95")

96. Si estas pica'o no guies................ (PUNCH "96")

97. Other, specify _..97

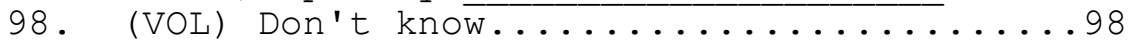

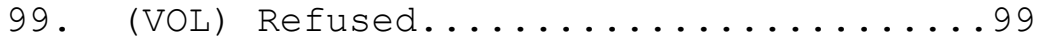

Q20c.I'd like to find out if you recall seeing a particular ad on TV recently. It starts with police pulling over drivers, and asking if they had been drinking alcohol. The drivers are then told to step out of the car, and tested to see if they are breaking the drinking and driving laws. The ad ends with the drivers handcuffed, placed in a police car, and shows their mug shots. Do you recall seeing this ad in the past two weeks?

Yes............

No..........
Don $t$ know...3 SKIP TO Q21
Refuse.......

Q20d. What was the slogan or logo used at the end of this ad? [DO NOT READ - MULTIPLE RECORD] 
You drink and drive, you lose.......

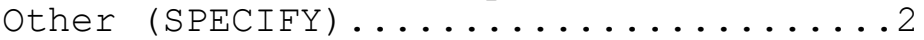

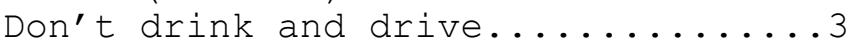

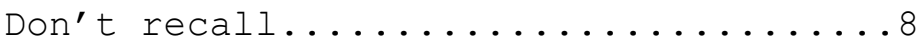

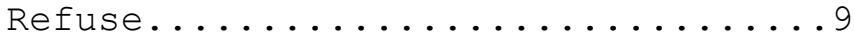

Q21. Do you recall seeing or hearing the following slogans in the past 30 days? [READ ITEMS NOT IN Q20b AND MULTIPLE RECORD]

1. Friends don't let friends drive drunk.....(PUNCH "1") (All)

2. You Drink and Drive. You Lose............(PUNCH "2") (All)

3. Get the keys................... (PUNCH "3") (All)

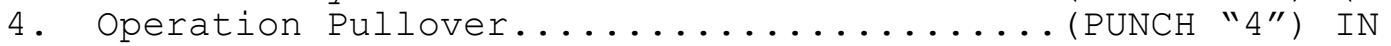

5. Why Risk It.................... (PUNCH "5") NV

6. Please Step Away from Your Vehicle. DUI...(PUNCH "6") PA

7. Checkpoint StrikeForce............. (PUNCH "7")

$\mathrm{DE}, \mathrm{DC}, \mathrm{MD}, \mathrm{PA}, \mathrm{VA}, \mathrm{WV}$

8. Booze It and Lose It........................... " 8 ") NC TN

9. Step Away From your Vehicle.................................. "9") TN

10. Checkpoint Tennessee................ PUNCH "10") TN

11. Team DUI..................... PUNCH "11") PA

12. Drive Hammered, Get Nailed............. (PUNCH "12") AK, AZ, IL, WA

13. Border to border................... PUNCH "13")

$A L, A R, G A, K Y, M O, M S$,

14. Operation Zero Tolerance............................... "14") GA

15. Do Buckle - Don't Booze............... PUNCH "15") ND

16. There's NO EXCUSE for Drunk Driving........ (PUNCH "16") KS

17. Get a Designated Driver. Or Pay the Price. (PUNCH "17") MN

18. Arrive Alive! Don't Drink and Drive...... (PUNCH "18") NV

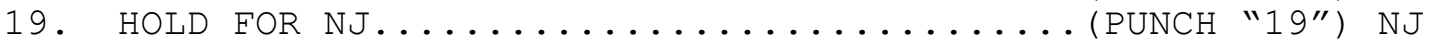

20. Don't Drink \& Drive or We Will stop You... (PUNCH "20") NM

21. Think Safe, Drive Sober.......................... "21") NY

22. Sober or SLAMMER............................... "22") SC

23. Santa's Coming, Don't Hit Him...........(PUNCH "23") TX

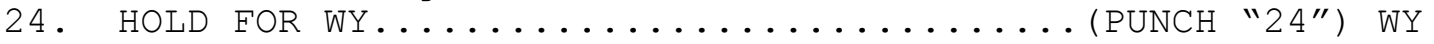

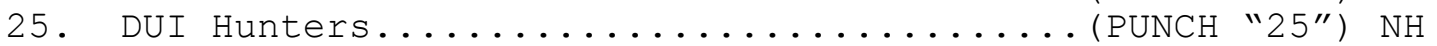

30. Recovery Month................................. "30") (ALL)

93. Keoki Kool (designated driver)........... (PUNCH "93") HI

94. Avoid the $23 \ldots \ldots \ldots \ldots \ldots \ldots \ldots \ldots \ldots \ldots \ldots \ldots \ldots \ldots$ PUNCH "94") CA SF

95. Avoid the $50 \ldots \ldots \ldots \ldots \ldots \ldots \ldots \ldots \ldots \ldots \ldots \ldots \ldots \ldots$ PUNCH "95") CA LA

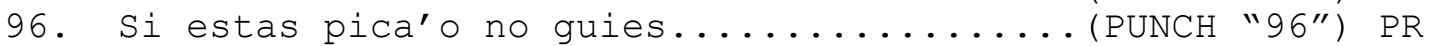

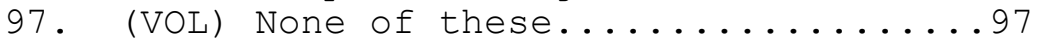

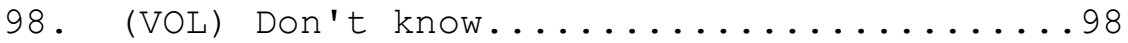

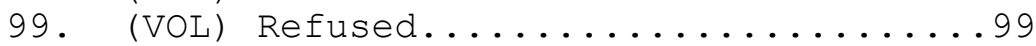

Q22. Thinking about everything you have heard, how important do you think it is for [STATE] to enforce the drinking and driving laws more strictly. . . very important, fairly important, just somewhat important, or not that important?

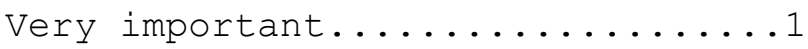

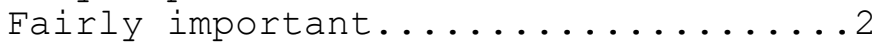

Just somewhat important...........

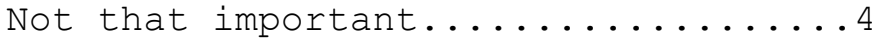

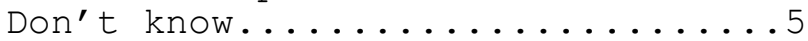

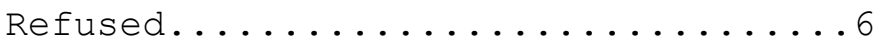




\section{DEMOGRAPHICS}

Now I need some information about you

D1. GENDER BY OBSERVATION

Male.........

Female.........2

D2. What is your age?

AGE REFUSED=99

D3. Do you consider yourself to be Hispanic or Latino?

Yes.................

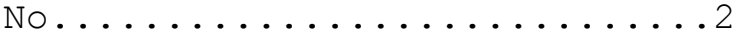

(VOL) Not sure........

(VOL) Refused..............

D4. Which of the following racial categories describes you? You may select more than one. [READ LIST--MULTIPLE RECORD]

American Indian or Alaska Native............

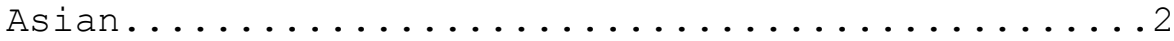

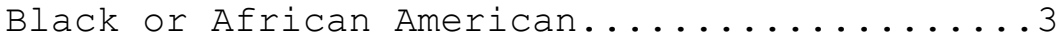

Native Hawaiian or other Pacific Islander.........4

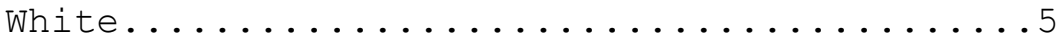

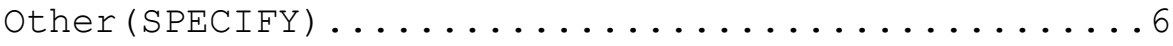

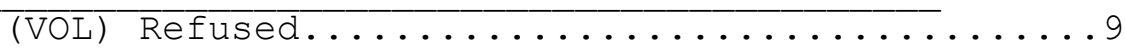

D5 What is the highest grade or year of school you completed?

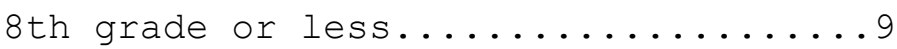

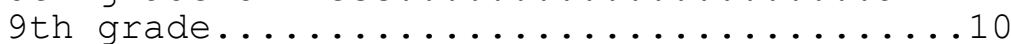

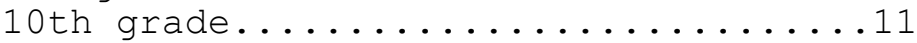

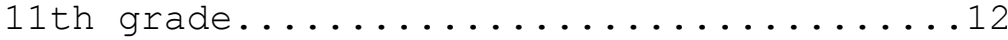

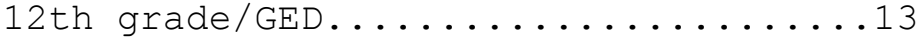

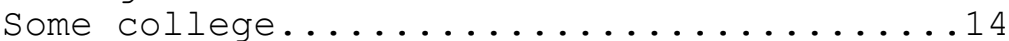

College graduate or higher...........15

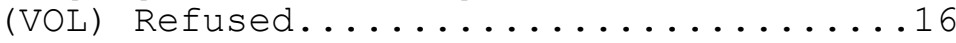

D6. Not including cell phones, and phones used primarily for fax or computer lines, do you have more than one telephone number in your household?

Yes.............

No ........................

Don't know......3

That completes the survey.

Thanks for taking the time to participate in this research study 

DOT HS 810792

August 2007 